AperTO - Archivio Istituzionale Open Access dell'Università di Torino

Pre-Cenozoic evolution of the Aghil Range (western Tibetan Plateau): A missing piece of the Tibet-Pamir-Karakorum geopuzzle

This is a pre print version of the following article:

Original Citation:

Availability:

This version is available http://hdl.handle.net/2318/1711559

since 2019-09-10T15:14:08Z

Published version:

DOI:10.1016/j.gr.2018.12.006

Terms of use:

Open Access

Anyone can freely access the full text of works made available as "Open Access". Works made available under a Creative Commons license can be used according to the terms and conditions of said license. Use of all other works requires consent of the right holder (author or publisher) if not exempted from copyright protection by the applicable law. 

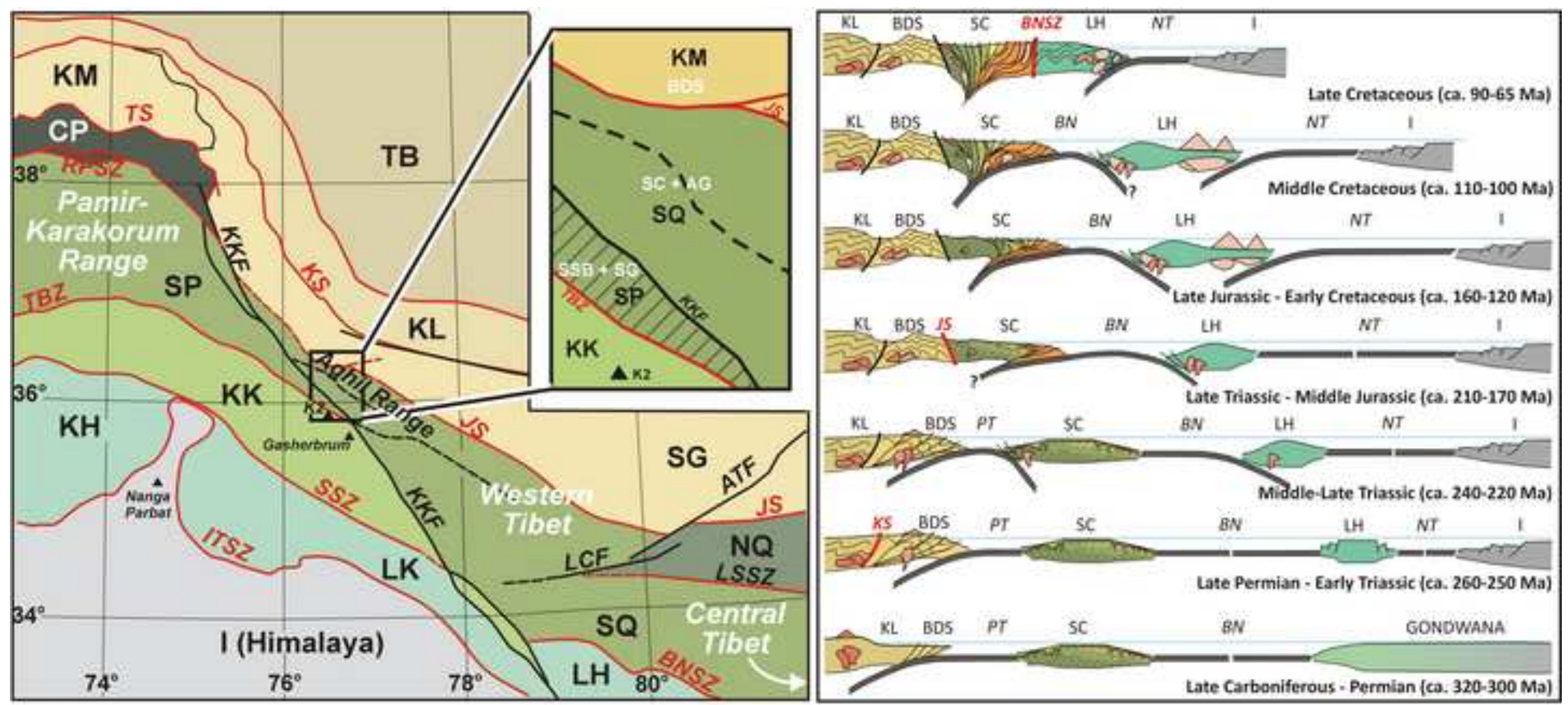
Research highlights:

- The pre-Cenozoic evolution of the Aghil Range (western Tibet) is investigated

- A coherent slice of Neoproterozoic basement with its sedimentary cover is preserved

- A correlation between terranes of Central Tibet and Pamir-Karakorum is proposed 
1

\section{Pre-Cenozoic evolution of the Aghil Range (western Tibetan Plateau): a missing piece of the Tibet-Pamir-Karakorum geopuzzle}

Chiara Groppo ${ }^{a}$, Franco Rolfo ${ }^{a^{*}}$, William C. McClelland ${ }^{b}$, Matthew A. Coble ${ }^{c}$

${ }^{a}$ Department of Earth Sciences, University of Torino, Torino, Italy and CNR-IGG, Torino

${ }^{b}$ Department of Earth and Environmental Sciences, University of lowa, lowa City, lowa 52242, USA

${ }^{\mathrm{C} D e p a r t m e n t}$ of Geological Sciences, Stanford University, Stanford, California 94305, USA

*Corresponding author:

Franco Rolfo

Department of Earth Sciences, University of Torino,

Via Valperga Caluso 35, 10125 Torino, Italy

e-mail: franco.rolfo@unito.it 


\section{Abstract}

The Tibetan Plateau, largely derived from the accretion of several Gondwana microplates to the southern margin of Asia since the late Palaeozoic, is the highest and largest topographic relief on Earth. Although the first order geodynamic processes responsible for its pre-Cenozoic evolution are quite well-known, many issues are still debated, among which is the timing of collision of each terrane with the southern margin of Asia. Even more uncertain is the pre-Palaeozoic history of these terranes, due to the lack of basement exposures. As a contribution to understanding the pre-Cenozoic evolution of the Tibetan Plateau, this paper focuses on the Aghil Range, a remote and poorly investigated area close to the Karakorum Fault between Kunlun and Karakorum (Xinjiang, China) in western Tibet. The tectono-metamorphic and magmatic evolution of the Aghil Range is investigated using a multidisciplinary approach that combines field mapping, petrology and geochronology (U-Pb on titanite, zircon, monazite and xenotime using SHRIMP-RG). We demonstrate that the Aghil Range preserves a coherent slice of Neoproterozoic crystalline basement with a late Palaeozoic sedimentary cover deposited on a passive continental margin during the Gondwana breakup. This represents the westernmost exposure of Precambrian crystalline basement known so far in the Tibetan Plateau. Furthermore, petrological and geochronological results allow reconstructing the Mesozoic poly-metamorphic evolution of this sector of the Tibetan Plateau, which records the evidence of Middle Jurassic (ca. $170 \mathrm{Ma}$ ) and Late Cretaceous (66 Ma) collisional events, as well as of the Late Jurassic (ca. 150 $\mathrm{Ma}$ ) early subduction of an accretionary complex developed on its southern margin. Evidence of Late Cretaceous subduction-related magmatism preceding the last collisional event is also recorded. These results allow tentative correlation of the different terranes of Central Tibet with those of the PamirKarakorum Range on both sides of the Karakorum fault.

\section{Key-words}

Tibetan Plateau, pre-Cenozoic evolution, Cimmerian orogeny, petrology, U-Pb geochronology

\section{Research highlights}

- The pre-Cenozoic evolution of the Aghil Range (western Tibet) is investigated

- A coherent slice of Neoproterozoic basement with its sedimentary cover is preserved

- A correlation between terranes of Central Tibet and Pamir-Karakorum is proposed 


\section{Introduction}

The Tibetan Plateau, together with the Pamir-Karakorum Range, is the highest and largest topographic plateau on Earth: understanding its formation and evolution is therefore fundamental for clarifying the geodynamic processes leading to crustal thickening and continental growth. The origin, evolution and tectonic architecture of the Tibetan Plateau and of the Pamir-Karakorum Range have been studied for several decades (e.g. Sengör, 1979, 1987; Allégre et al., 1984; Sengör, 1987; Dewey et al., 1988; Gaetani et al., 1990a,b, 1993; Burtman and Molnar, 1993; Matte et al., 1996; Gaetani, 1997; Yin and Harrison, 2000); important advances in understanding their genesis have been made over the last ten years thanks to an increasing number of field, geochemical and geochronological studies as demonstrated by publication of numerous review papers (e.g. Zhang et al., 2012; Zhu et al., 2011, 2013) and special volumes dedicated to this topic (e.g. Zhang and Santosh, 2012; Zanchi et al., 2015; Chung and Niuetat., 2016; Zhang et al., 2017).

It is now widely accepted that the Tibetan Plateau and Pamir-Karakorum Range derive from the accretion of several Gondwana-derived microplates (also called Cimmerian terranes: Sengör, 1984) to the southern margin of Asia since the late Palaeozoic, in response to the ongoing subduction and progressive closure of the oceanic basins between each terrane (e.g. Allégre et al., 1984; Dewey et al., 1988; Yin and Harrison, 2000; Pan et al., 2012). Moreover, there is increasing evidence that most of the deformation, shortening and crustal thickening within the plateau were the result of these pre-Cenozoic accretionary processes whereas the contribution of India-Asia collision to the building of the plateau was only minor (e.g. Murphy et al., 1997; Yin and Harrison, 2000; Hildebrand et al., 2001; Robinson et al., 2004; Kapp et al., 2003b, 2005, 2007; Guynn et al., 2006; Zhang et al., 2012; Zhu et al., 2013). However, several recent studies explain crustal thickening as related to the underthrusting of Indian lithosphere (e.g. Chen et al., 2017). Although the first order geodynamic processes responsible for the pre-Cenozoic evolution of the plateau are quite well-known, many issues are still debated. These include the timing, duration and direction of oceanic subduction and the timing of collision of each terrane with the southern margin of Asia. Even more uncertain is the Precambrian history of the Cimmerian terranes, due in large part to the scarcity of basement exposures and the predominance of late Palaeozoic or younger supracrustal assemblages (e.g. Pan et al., 2004; Guynn et al., 2012; Zhu et al., 2013 and references therein).

Most studies devoted to understanding the pre-Cenozoic formation and evolution of the Tibetan Plateau and Pamir-Karakorum Range are based on either stratigraphic evidence (e.g. Gaetani et al., 1990b, 1993; Gaetani, 1997; Kapp et al., 2007; Zanchi and Gaetani, 2011; Zanchi et al., 2012; Angiolini et al., 2013, 2015; Gaetani and Leven, 2014; Robinson, 2015; Zeng et al., 2016) or on the distribution, composition and age of subduction- and/or collision- related magmatic rocks (e.g. Schwab et al., 2004; Zhu et al., 2011, 2013; Zhang et al., 2012 and references therein; Zanchetta et al., 2018). Studies of metamorphic rocks are sporadic and limited to few areas, such as the Central Qiangtang Metamorphic Belt (e.g. Kapp et al., 2000, 
2003a; Pullen et al., 2008, 2011; Liang et al., 2012; Zhai et al., 2011b; Zhao et al., 2014), the Amdo terrane (e.g. Guynn et al., 2006, 2012, 2013; Zhang et al., 2012a), the Central Lhasa terrane (e.g. Dong et al., 2011; Zhang et al., 2012b ; Zhang et al., 2014) and the southern Karakorum Terrane (e.g. Searle and Tirrull, 1991; Lemennicier et al., 1996; Fraser et al., 2001; Streule et al., 2009; Searle, 2011).

As a contribution to the understanding of the pre-Cenozoic evolution of the Tibetan Plateau, this study focuses on the metamorphic and magmatic units exposed along the Aghil Range, a remote and poorly investigated area located at the junction between the Tibetan Plateau and the Pamir-Karakorum Range in western Tibet. Interpretation of this area is still controversial, having been alternatively ascribed to the Songpan-Ganze (Tianshuai) terrane (e.g. Valli et al., 2008; Leloup et al., 2012; Pan et al., 2012) or to the Southern (or Western) Qiangtang terrane (e.g. Gaetani et al., 1990a; Robinson, 2009, 2015; Groppo and Rolfo, 2008; Streule et al., 2009; Searle et al., 2010, 2011; Gaetani and Leven, 2014; Rolfo et al., 2014). The aim of this study is therefore twofold: (i) to understand the geological significance of the Aghil Range and assess the nature of the boundaries between the various terranes on both sides of the Karakorum Fault; (ii) to tentatively reconstruct the pre-Cenozoic history of accretion, collision, metamorphism and magmatism of the western portion of the Tibetan Plateau, in comparison with the better known evolution of the central portion of the plateau.

We present field, petrographic, petrologic and geochronologic data on both metamorphic and magmatic rocks exposed along a geological transect, approximately $40 \mathrm{~km}$ long, located between the Kunlun to the north and the Karakorum to the south (Xinjiang, China). The studied metamorphic rocks belong to two different tectonic units (Gaetani et al., 1990a): the "Bazar Dara Slates", a metasedimentary unit located few km south of Mazar (not to be confused with the thick terrigenous Bazardara Series of SE Pamir, which are tentatively correlated with the Singhiè Formation of the Shaksgam Sedimentary Belt by Gaetani and Leven, 2014), and the "Surukwat Complex", a composite sequence of metamorphic thrust sheets derived from both magmatic and sedimentary protoliths. Two granodioritic bodies (i.e. Aghil Granodiorite and Sughet Granodiorite) tectonically interposed between these metamorphic units have been investigated as well.

The petrological and geochronological results allow us to: (i) clarify how the Cimmerian terranes are assembled on both sides of the Karakorum fault (i.e. in the western Tibetan Plateau and in the PamirKarakorum Range); (ii) demonstrate that the Surukwat Complex represents the westernmost exposure of a Precambrian crystalline basement known so far in the Tibetan Plateau; (iii) reconstruct the Mesozoic polymetamorphic evolution of both the Bazar Dara Slates Unit and the Surukwat Complex which record the evidence of Middle Jurassic and Late Cretaceous collisional events, as well as the Late Jurassic early subduction of an accretionary complex developed on the southern margin of the Surukwat Complex; (iv) recognise evidence of Late Cretaceous subduction-related magmatism preceding the collision of the Lhasa and South Qiangtang terranes; and (v) confirm the diachronicity, from east to west, of the Cretaceous 
collisional event between the Lhasa and South Qiangtang terranes in western Tibet and between the Kohistan-Ladakh and Karakorum terranes in Pamir-Karakorum .

\section{Geodynamic Setting of the Tibetan Plateau and Pamir-Karakorum Range}

\subsection{Tibetan Plateau}

The Tibetan Plateau consists of four main E-W trending crustal terranes that rifted from the eastern margin of Gondwana during the late Palaeozoic, drifted northward across the Tethyan Ocean basins and then progressively accreted to the southern margin of Asia during the Mesozoic (e.g. Allégre et al., 1984; Sengör, 1987; Yin and Harrison, 2000). In central Tibet, the following terranes are conventionally distinguished from north to south (Fig. 1a): Kunlun, Songpang-Ganze, Qiangtang and Lhasa terranes. The boundaries between these terranes coincide with different suture zones resulting from the closure of the ocean basins originally interposed between each terrane, and now marked by discontinuous belts of ophiolite fragments and mèlange:

- The Jinsha Suture (JS) separates the Songpan-Ganze terrane from the Qiangtang terrane and records closure of the Paleo-Tethys Ocean; the Songpan-Ganze terrane is commonly interpreted as an extensive arc-accretionary system built along the southern margin of Kunlun during the Triassic (e.g. Matte et al., 1996; Schwab et al., 2004), whose huge volume of sediments did not allow a complete continentcontinent collision between Kunlun and Qiangtang (e.g. Roger et al., 2010).

- The Bangong-Nujiang Suture Zone (BNSZ), more than $1200 \mathrm{~km}$ long, separates the Qiangtang terrane from the Lhasa terrane and resulted from the closure of the Bangong-Nujiang Ocean (or Meso-Tethys Ocean; Sengör, 1984). In western and eastern Tibet, the BNSZ ophiolitic belt is doubled and isolates two micro-blocks interposed between Qiangtang and Lhasa terranes: the Risum block to the west and the Amdo terrane to the east. The Risum block is interpreted as an oceanic arc formed by the intra-oceanic subduction of the Bangong-Nujiang Ocean (Matte et al., 1996; Shi et al., 2004; Shi, 2007; Liu D. et al., 2017). The Amdo terrane is an old micro-continent within the Bangong-Nujiang Ocean that amalgamated with the Qiangtang block before the Lhasa-Qiangtang collision (Xu et al., 1985; Guynn et al., 2006). The Amdo block has been variably correlated to the Lhasa terrane (e.g. Coward et al., 1988; Harris et al., 1988; Yin and Harrison, 2000; Pan et al., 2004) or the Qiangtang terrane (e.g. Guynn et al., 2006, 2012; Zhu et al. 2013).

- The 2000-km-long Indus-Tsangpo Suture Zone (ITSZ) represents the site where the Neo-Tethys lithosphere separating the Lhasa terrane and north India was consumed at a subduction zone dipping northward beneath the Lhasa terrane (Yin and Harrison, 2000). 
- The Longmu Tso-Shuanghu Suture Zone (LSSZ) divides the Qiangtang terrane in two sub-terranes: the North (or Eastern) Qiangtang terrane and the South (or Western) Qiangtang terrane. This suture zone is spatially associated with a high-pressure metamorphic belt (Central Qiangtang Metamorphic Belt, CQMB: Kapp et al., 2000, 2003a), and its origin is still debated. The CQMB has been interpreted either: (i) as a part of the Songpan-Ganze accretionary mèlange that was underthrusted beneath a single Qiangtang terrane during the southward subduction of the Paleo-Tethys along the Jinsha Suture in the early Mesozoic (i.e. underthrust model: e.g. Kapp et al., 2000, 2003a; Kapp, 2001; Pullen et al., 2011), or (ii) as an in situ suture zone formed by northward subduction of a branch of Paleo-Tethys originally separating the South Qiangtang terrane of Gondwanan affinity from the North Qiangtang terrane of Cathaysian affinity (i.e. intra-Qiangtang suture model: e.g. Zhang, 2001; Zhang et al., 2006a,b, 2011; Zhang and Tang, 2009; Liu et al., 2011; Zhai et al., 2011a,b, 2013; Zhu et al., 2013; Zhao et al., 2014).

The timing, duration and direction of oceanic subduction, as well as the timing of final collision between each terrane are still debated. The Paleo-Tethys ocean was subducted northward beneath the Kunlun and Songpan-Ganze terranes by the Late Permian - Early Triassic, as evidenced by the occurrence of a magmatic belt and volcanic arc along the southern margin of Kunlun (e.g. Matte et al., 1996; Xiao et al., 2002, 2003; Liu et al., 2015; Cao et al., 2015); southward subduction in Late Triassic - Early Jurassic times is instead proposed by other studies (e.g. Kapp et al., 2000, 2003a; Zhang et al., 2016). The final collision between the Qiangtang and the Songpan-Ganze/Kunlun terranes occurred in the Late Triassic to Middle Jurassic. The southernmost Bangong-Nunjiang ocean was subducted either northward under the South Qiangtang terrane, or southward beneath the Lhasa Terrane during the Mesozoic (Zhu et al., 2013; Liu D. et al., 2017 and references therein). This was likely an oblique subduction, resulting in a diachronous collision of the Lhasa and Qiangtang terranes from west (Middle Cretaceous) to east (Late Cretaceous) (e.g. Matte et al., 2006; Zhang et al., 2008; Zhu et al., 2013; Liu L. et al. 2017; Liu D. et al., 2017 and references therein).

\subsection{Pamir-Karakorum Range}

The dextral strike-slip Karakorum fault (KKF) (e.g. Phillips et al., 2004; Searle and Phillips, 2007; Phillips, 2008; Valli et al., 2008; Robinson, 2009; Leloup et al., 2011) separates the Tibetan Plateau to the east from the Pamir-Karakorum Range to the west, whose tectonic framework is also the result of the amalgamation of different Gondwana-derived terranes. From north to south these terranes are the Kunlun, Karakul-Mazar (or North Pamir), Central Pamir, South Pamir, Karakoram and Kohistan-Ladakh, and they are bounded by the Kunlun, Tanymas, Rushan-Pshart, Tirich Boundary Zone and Shyok suture zones, respectively (Fig. 1a). The correlation between crustal terranes and suture zones of Pamir-Karakorum and central Tibet is not univocal (e.g. Burtman and Molnar, 1993; Yin and Harrison, 2000; Lacassin et al., 2004; Schwab et al., 2004; Robinson, 2009, 2015; Robinson et al., 2012; Zanchetta et al., 2018). The Karakul-Mazar terrane, bounded 
by the Kunlun suture to the north and the Tanymas Suture to the south, is commonly considered the equivalent of the Songpan-Ganze terrane of central Tibet. Interpretation of the other terranes is less certain. Recent studies suggest that the Central Pamir, South Pamir and Karakoram terranes are correlative to the Qiangtang terrane (e.g. Phillips et al., 2004; Upadhyay et al., 2005; Searle and Phillips, 2007; Robinson et al., 2004; Robinson, 2009, 2015; Searle et al., 2010; Searle, 2011; Angiolini et al., 2013; Yang et al., 2017) and that the Kohistan-Ladakh terrane and the Lhasa terrane of central Tibet are part of a continuous magmatic arc, built on a continental basement in the Lhasa terrane and in the Ladakh region, and on oceanic crust in the Kohistan terrane (e.g. Rolfo et al., 1997; Yin and Harrison, 2000; Robinson et al., 2004; Robinson, 2009, 2015). Following this interpretation, the Shyok Suture, that separates the Karakorum terrane from the Kohistan-Ladakh terrane, would be the equivalent of the Bangong-Nunjiang suture zone. However, other studies suggest that South Pamir is the equivalent of the Lhasa terrane (e.g. Lacassin et al., 2004; Schwab et al., 2004), in which case the Rushan-Pshart Suture Zone would be equivalent to the Bangong-Nunjiang suture zone. An absence of direct correlations between major suture zones east and west of the Karakorum Fault has been also recently proposed (Zanchetta et al., 2018). A better understanding of the western Tibet region and the Aghil Range where the study area is located in particular, is crucial for meaningful correlation of crustal terranes across the Karakorum fault.

\section{Geological Setting}

The Aghil Range in western Tibet (Fig. 1a) was studied along a cross-section between llik (at the confluence between the Yarkand and the Zug Shaksgam rivers) and Sughet Jagal (northern K2 base camp, along the Sarpo Laggo Valley), across the Aghil pass and the Shaksgam Valley (Fig. 1b). Very few geological studies have been performed in this area, tectonically sandwiched between Kunlun to the north and Karakorum to the south. The first "modern", though preliminary, data are reported in Gaetani et al. (1990a, 1991); these results already documented the complexity of the area, characterized by the juxtaposition of different metamorphic, sedimentary or magmatic units. More recently, Groppo and Rolfo (2008) reported the evidence of a possibly old metamorphic basement north of Aghil Pass (i.e. the Surukwat Complex), and constrained the P-T evolution of its structurally upper portion. However, the nature and age of this basement is still unknown, as well as the age of metamorphism. The non-metamorphic Shaksgam Sedimentary Belt was investigated in detail by Gaetani et al. (1990a, 1991) and Gaetani and Leven (2014), whereas the magmatic rocks exposed close to the Aghil Pass (i.e. the Aghil Granodiorite) were studied very recently by Liu L. et al. (2017). Detailed description of the lithological and tectonic architecture along the llik - Sughet Jagal transect and relevant images of field geology and mesoscopic structures are given by Rolfo et al. (2014) and will only be summarized here. 
Starting from llik and going upstream (southward) along the Aghil Dara Valley, the Bazar Dara Slates Unit (Fig. 1b) is a metasedimentary sequence consisting mainly of phyllites and metasandstones that are dipping steeply towards SSE and locally intruded by undeformed Late Triassic granitic bodies (e.g. Mazar from the Surukwat Complex; this is a composite sequence of thrust sheets steeply dipping SSW (Fig. 1b,d) in which, except for a few non-metamorphic slivers, there is a general southward increase in metamorphic grade from lower to higher structural levels (Rolfo et al., 2014). Although pervasively mylonitized, the internal coherence of this basement is mostly preserved (Fig. 1c). From north to south, the Surukwat Complex starts with a non-metamorphic sliver of red sandstone with anhydrite interlayers that shows a strong affinity with the Qiangtang terrane (Leeder et al., 1988), and is petrographically similar to the Jurassic Marpo Sandstone of the Shaksgam Valley (Gaetani et al., 1990a, 1991). A metamorphic basement derived from igneous protoliths is thrust over the red sandstone to the south (Fig. 1d). From lower to higher structural levels it consists of meta-diorite, meta-granodiorite and meta-granite with transposed meta-aplitic dykes. Primary intrusive relationships between the various magmatic protoliths have been obliterated by the pervasive mylonitic deformation which affected this portion of the Surukwat Complex. A small (few-meters-thick) slice of slightly metamorphosed limestone is tectonically intercalated in this metaigneous basement. A few-kilometers-thick layer of metaconglomerate dominated bv granitic and dioritic clasts follows further upstream. Further south, the metaconglomerate is overlain by a km-thick metasedimentary sequence that consists of quartzite, quartzitic gneiss and metapelite with meter-thick intercalations of meta-marl (amphibole-bearing calcschist, biotitic-amphibolitic schist, carbonate-rich garnet-bearing biotitic schist) and impure marble. The medium grade metapelites represent the last unit of the Surukwat Complex, which is bounded to the south by a sharp fault contact with the Aghil intrusive body (Fig. 1b,d). A weakly deformed apophysis of this pluton crops out within the quartzitic gneisses to the north. The Aghil intrusive body mainly consists of amphibole + biotite -bearing granodiorite, with minor monzonite and porphyritic granite, the latter cropping out in the proximity of the Aghil Pass. A Late Cretaceous age has been recently obtained for these magmatic rocks (zircon U-Pb ages; Liu L. et al., 2017).

Another tectonic contact is crossed southward just before the Aghil Pass (Fig. 1b,d) that separates the Aghil Granodiorite from the Shaksgam Sedimentary Belt (Gaetani et al., 1990a, 1991), a 250 km long and 15-20 km wide sedimentary sequence exposed along the Shaksgam Valley and extending to the west of the Karakorum fault for $\sim 150 \mathrm{~km}$ in southeast Pamir (Robinson, 2009). This sedimentary sequence, displaced in a system of open folds, faulted, thrusted and stacked together, is at least $3 \mathrm{~km}$ thick and spans from the Lower Permian to Jurassic (Gaetani et al., 1990a, 1991; Gaetani, 1997; Gaetani and Leven, 2014). The main strand of the Karakorum Fault is crossed a few kilometres south of the junction between the Sarpo Laggo and Shaksgam valleys (Fig. 1b,d). A cataclastic contact separates the Shaksgam Sedimentary Belt (Aghil Dolomite) from the Sughet Granodiorite. This plutonic body, mostly made of biotite-bearing 
granodiorite, crops out in the lower (northern) part of the Sarpo Laggo valley, near Sughet Jagal, and represents the last unit of the investigated geological transect.

This study focuses on six representative samples from the Bazar Dara Slates Unit (BDS: sample 0601), the Surukwat Complex (SC: samples 06-10, 06-17 and 06-115) and the Aghil and Sughet magmatic bodies (samples 06-26 and 06-108). These samples have been selected out of a total of 76 samples (BDS; 16 samples; SC: 54 samples; magmatic bodies: 6 samples) after careful petrographic characterization of the entire sample suite.

\section{Methods}

\subsection{Mineral chemistry}

Minerals were analysed with a Cambridge Stereoscan 360 SEM equipped with an EDS Energy 200 and a Pentafet detector (Oxford Instruments) at the Department of Earth Sciences, University of Torino. The operating conditions were as follows: accelerating voltage was set to $15 \mathrm{kV}$, beam diameter was $2 \mu \mathrm{m}$, and detection limits for oxides were $0.03 \mathrm{wt} \%$. SEM-EDS quantitative data were acquired and processed using the Microanalysis Suite Issue 12, INCA Suite version 4.01; natural mineral standards were used to calibrate the raw data; the $\rho \phi Z$ correction (Pouchou and Pichoir, 1988) was applied. Absolute error is $1 \sigma$ for all calculated oxides. Mineral chemical data of representative minerals are reported in Table 1.

\subsection{Determination of peak P-T conditions in the metamorphic samples}

P-T conditions for all the metamorphic samples were estimated using the "Average PT" routine of THERMOCALC (Holland and Powell, 1998, version 3.33, thermodynamic database 5.5). Activity-composition relationships were calculated using AX. This method, which estimates the optimal P-T conditions using a set of independent reactions that fully describe the thermodynamics of the system, is able to find a result only if the given mineral assemblage defines a sufficient number of reactions between end-members. The obtained results were considered reliable if passed the 'sigfit' test ( $\sigma$ fit < cutoff value), giving P-T uncertainties ( $\sigma \mathrm{T}$ and $\sigma \mathrm{P})$ at $\pm 1 \sigma\left(95 \%\right.$ confidence). End member(s) with erratic behaviour (large $e^{*}$ values) and a low influence on the least squares results (low hat values) were removed from the calculation because they may cause inconsistency in the results (see Powell and Holland, 1994). A pure $\mathrm{H}_{2} \mathrm{O}$ fluid was considered in the calculations. Average P-T results are reported in Table 2.

The pseudosection approach cannot be applied on most of the studied samples. Sample 06-1 (Bazar Dara Slates phyllite) contains significant amounts of calcite, mostly concentrated in late veins, and it is not 
possible to obtain the equilibrium bulk composition needed for the pseudosection calculation. Similarly, an equilibrium bulk composition cannot be determined for samples 06-10 and 06-17 (meta-granodiorite and meta-diorite from the Surukwat Complex), which are clearly not completely re-equilibrated, as suggested by the presence of relict magmatic hornblende crystals (see section 4.1.2). Therefore, the pseudosection approach has been applied only on sample 06-115 (two-micas, garnet-bearing micaschist from the Surukwat Complex). The pseudosection for this sample was already calculated by Groppo and Rolfo (2008) and it was used to constrain its complete P-T evolution.

\subsection{Geochronology and Trace Element Analyses}

$\mathrm{U} / \mathrm{Pb}$ geochronology was performed on zircon separated from igneous samples $(06-26,06-108)$ and titanite, monazite, and xenotime in-situ on polished thin sections of metamorphic rocks (06-1, 06-10, 06-17, 06-115), using the SHRIMP-RG (sensitive high-resolution ion microprobe with reverse geometry) instrument at the Stanford-U.S. Geological Survey Micro-Analysis Center at Stanford University.

Heavy mineral separates from granitoid samples 06-26 and 06-108 were obtained by standard pulverizing, magnetic and heavy liquid methods. Individual zircon grains were handpicked under alcohol, mounted in epoxy resin with natural zircon standards and polished to expose the grain centers for analysis by secondary ion microprobe spectrometry (SIMS). Zircon grains were imaged by cathodoluminescence (CL) to expose intra-grain zoning or complexity and aid in placing SIMS spots. The U-Pb and trace element analysis (Tables 3 and SM1a) was performed simultaneously following routines outlined in Barth and Wooden $(2006,2010)$. Instrument mass fractionation corrections were calibrated by replicate analysis of the zircon standard R33 zircon (419 Ma; Black et al., 2004) with a $2 \sigma$ calibration error for the $\mathrm{R} 33{ }^{206} \mathrm{~Pb} /{ }^{238} \mathrm{U}$ ratio of $0.69 \%$ for the analytical session added in quadrature. Ages were calculated from ${ }^{206} \mathrm{~Pb} /{ }^{238} \mathrm{U}$ ratios corrected for common $\mathrm{Pb}$ using the ${ }^{207} \mathrm{~Pb}$ method using measured ${ }^{207} \mathrm{~Pb} /{ }^{206} \mathrm{~Pb}$ ratios or using the ${ }^{204} \mathrm{~Pb}$ method (see Williams, 1998). The U concentration was calibrated with Madagascar Green (MAD-559; 3940 ppm U,Coble et al., 2018). Data reduction and plotting utilized programs Squid 2.51 and Isoplot 3.76 of Ludwig $(2009,2012)$.

The acquisition routine included ${ }^{89} \mathrm{Y},{ }^{139} \mathrm{La},{ }^{140} \mathrm{Ce},{ }^{146} \mathrm{Nd},{ }^{147} \mathrm{Sm},{ }^{153} \mathrm{Eu},{ }^{155} \mathrm{Gd},{ }^{163} \mathrm{Dy}^{16} \mathrm{O},{ }^{166} \mathrm{Er}^{16} \mathrm{O}$, ${ }^{172} \mathrm{Yb}^{16} \mathrm{O},{ }^{90} \mathrm{Zr}_{2}{ }^{16} \mathrm{O}$, and ${ }^{180} \mathrm{Hf}^{16} \mathrm{O}$ simultaneous with $\mathrm{U} / \mathrm{Pb}$ analysis. In a separate analytical session, additional trace element analyses were performed, including ${ }^{27} \mathrm{Al},{ }^{30} \mathrm{Si},{ }^{31} \mathrm{P},{ }^{39} \mathrm{~K},{ }^{40} \mathrm{Ca},{ }^{28} \mathrm{Si}^{16} \mathrm{O},{ }^{45} \mathrm{Sc},{ }^{48} \mathrm{Ti},{ }^{49} \mathrm{Ti},{ }^{56} \mathrm{Fe},{ }^{89} \mathrm{Y}$, ${ }^{93} \mathrm{Nb},{ }^{94} \mathrm{Zr}^{1} \mathrm{H}$, and ${ }^{96} \mathrm{Zr}$. Each isotope was normalized to ${ }^{28} \mathrm{Si}^{16} \mathrm{O}$ or ${ }^{90} \mathrm{Zr}_{2}{ }^{16} \mathrm{O}$, and concentrations were calibrated against zircon standard MAD-559 (Coble et al., 2018). The estimated errors based on repeated analysis of MAD-559 was 6 to $10 \%$ for $\mathrm{P}, \mathrm{Sc}, \mathrm{Ti}, \mathrm{Y}$ and $\mathrm{Nb}$. The uncertainty of $\mathrm{Al}, \mathrm{K}, \mathrm{Ca}$, and Fe were higher (up to $45 \%$ RSD), but these elements were measured only to evaluate if the analytical spot intersected an inclusion or alteration. For example, grain 0608-2.1, Sc, Nb, and Ti were omitted because $\mathrm{Al}, \mathrm{K}$ and Fe were 
$\sim 20$ to $100 x$ higher than other zircon from the same sample. Chondrite normalized plots were calculated using values from McDonough and Sun (1995). The ${ }^{49} \mathrm{Ti}$ data were used to determine the Ti content to avoid interference of ${ }^{96} \mathrm{Zr}^{2+}$ with the ${ }^{48} \mathrm{Ti}$ peak (Watson and Harrison, 2005). Ti-in-zircon temperatures were calculated using Ferry and Watson (2007), assuming the activity of $\mathrm{SiO}_{2}$ is equal to one $\left(a_{\mathrm{SiO} 2}=1\right)$ and activity of $\mathrm{TiO}_{2}$ is approximately $0.7\left(a_{\mathrm{TiO} 2}=0.7\right)$ for rutile-absent siliceous melts (Hayden and Watson, 2007).

Titanite (samples 06-10 and 06-17), monazite (06-115, 06-1), and xenotime (06-115, 06-1) were analyzed in-situ in polished thin sections that were cut into fragments and mounted with appropriate natural standards in large format epoxy mounts (megamounts). Elemental maps showing $\mathrm{U}, \mathrm{Y}, \mathrm{Ce}, \mathrm{P}, \mathrm{Ca}$, and Th concentrations of monazite and high contrast backscatter electron (BSE) images of titanite, monazite and xenotime were generated to identify zoning prior to analysis. Monazite element maps were collected on a JEOL JXA-0823 Electron Microprobe at the University of lowa and BSE imaging was performed at Stanford University using a JEOL 5600 SEM.

$\mathrm{U}-\mathrm{Pb}$ analysis of titanite (Tables 4 and SM1b) monazite (Tables 5 and SM1c), and xenotime (Tables 6 and SM1d) followed the same analytical routine used for zircon, except ${ }^{89} Y$ was not included in the acquisition table for xenotime and only $\mathrm{U}$ and Th were measured as trace elements for titanite. $\mathrm{U}-\mathrm{Pb}$ ages were standardized relative to 44069 monazite (425 Ma; Aleinikoff et al., 2006), MG-1 xenotime (490 Ma; Fletcher et al., 2010; Aleinikoff et al., 2012), and MMs titanite (524 Ma; Schoene and Bowring, 2006) reference materials for monazite, xenotime, and titanite unknown samples, respectively. For trace elements, each isotope was normalized ${ }^{140} \mathrm{Ce}^{31} \mathrm{P}^{16} \mathrm{O}_{2},{ }^{89} \mathrm{Y}^{16} \mathrm{O}_{2}$, or ${ }^{40} \mathrm{Ca}^{48} \mathrm{Ca}^{48} \mathrm{Ti}^{16} \mathrm{O}_{2}$, and trace element concentrations were standardized relative to 44069 monazite (calibrated relative to Namibia (NAM) monazite; Aleinikoff et al., 2012), MG-1 xenotime, or BLR titanite (Aleinikoff et al., 2007) for monazite, xenotime, and titanite, respectively.

Common $\mathrm{Pb}$ composition for titanite samples was determined by linear regression of all analyses on a 3D Tera-Wasserburg plot which yielded a data-defined ${ }^{207} \mathrm{~Pb} /{ }^{206} \mathrm{~Pb}$ upper intercept of 0.9096 , interpreted as the best estimate of the common $\mathrm{Pb}$ composition. All other mineral use initial common $\mathrm{Pb}$ isotopic composition approximated from Stacey and Kramers (1975). Data reduction for geochronology follows the methods described by Williams (1998) and Ireland and Williams (2003), using the MS Excel add-in programs Squid2.51 and Isoplot3.76 of Ken Ludwig $(2009,2012)$. For titanite, the ${ }^{206} \mathrm{Ub} /{ }^{238} \mathrm{U}$ calibration constant utilized a data-defined slope of 1.24 through the distribution of $\mathrm{MMs}$ analyses on a plot of $\ln \left(\mathrm{UO}^{+} / \mathrm{U}^{+}\right)$vs $\ln \left(\mathrm{Pb}^{+} / \mathrm{U}^{+}\right)$. Zircon was calculated with a fixed slope of 2.0. Monazite and xenotime analysis used energy filtering to eliminate the isobaric interference at mass ${ }^{204} \mathrm{~Pb}$, and a calibration of $\ln \left(\mathrm{UO}_{2}{ }^{+} / \mathrm{UO}^{+}\right)$vs $\ln \left(\mathrm{Pb}^{+} / \mathrm{UO}^{+}\right)$with a data-defined slope $(0.60$ and 2.14 , respectively), following methods modified from Fletcher et al. (2010) and Cross and Williams (2018). 


\section{Results}

\subsection{Petrography and petrology of the studied samples}

\subsubsection{Bazar Dara Slates Unit (sample 06-1)}

The Bazar Dara Slates Unit exposed along the lower Aghil Dara Valley consists of a metasedimentary sequence of sandstones, siltstones and slates, steeply dipping towards SSE and locally rich in deformed quartz + carbonate veins. Sample 06-1, collected ca. 4 km south-east of llik (N36²2'28.4" E7640'54.4" $3560 \mathrm{~m}$ ), is a two-micas + chlorite phyllite (meta-sandstone) consisting of quartz, muscovite, biotite, chlorite, calcite, minor albite and accessory ilmenite (Fig. 2a). Most calcite is a late phase, concentrated in millimetric veins either concordant or discordant with respect to the main foliation; however, it cannot be excluded that minor calcite is also present in the equilibrium assemblage. The main foliation $\left(S_{m}\right)$, defined by the preferred orientation of muscovite ( $\mathrm{Si}=3.13-3.25$ a.p.f.u. on the basis of 11 oxygens), chlorite $\left(\mathrm{X}_{\mathrm{Mg}}=\right.$ 0.53-0.54), biotite ( $\mathrm{X}_{\mathrm{Mg}}=0.51-0.54 ; \mathrm{Ti}=0.11-0.12$ a.p.f.u. $)$ and ilmenite, is pervasively crenulated, with the local appearance of an $S_{m+1}$ defined by white mica and ilmenite. Minor monazite and xenotime occur as anhedral grains with no clear relationship relative to the dominant foliation (Fig. 3).

Equilibrium P-T conditions for this sample were calculated for the $\mathrm{S}_{\mathrm{m}}$ assemblage $\mathrm{Qz}+\mathrm{Ab}+\mathrm{Chl}+$ $\mathrm{Mu}+\mathrm{Bt}+\| \mathrm{m}$, which resulted in $320 \pm 32{ }^{\circ} \mathrm{C}, 5.2 \pm 0.9 \mathrm{kbar}$ (i.e. greenschist-facies conditions) (Table 2). The rare occurrence of relict phengite flakes ( $\mathrm{Si}=3.32-3.39$ a.p.f.u.) partially replaced by muscovite suggests a complex metamorphic evolution, possibly characterized by an earlier high-pressure stage $\left(p r e-S_{m}: Q z+A b+\right.$ Chl + Phe) .

\subsubsection{Surukwat Complex (samples 06-10, 06-17, 06-115)}

\subsubsection{Meta-diorite and meta-granodiorite (samples 06-10 and 06-17)}

The lowermost portion of the Surukwat Complex consists of a sequence of strongly mylonitized metabasites of dioritic to granodioritic composition with sub-vertical attitude, alternating with granitic to aplitic layers (Fig. 1d). Sample 06-10 and 06-17 are representative examples of the most and less deformed lithologies, respectively.

Sample 06-10 (N36 $17^{\prime} 54,8^{\prime \prime} \mathrm{E}^{\circ} 6^{\circ} 35^{\prime} 22,8^{\prime \prime}$ - $3830 \mathrm{~m}$ ) is a mylonitized hornblende-bearing metagranodiorite still preserving mineralogical relics of the igneous protolith (Fig. 2 b). It is characterized by mmsized, sharply zoned amphibole porphyroclasts (Fig. 2 b,c), with a yellow-pale green relic core (i.e. Amp : $^{\circ}$ magmatic Mg-hornblende to edenite; $\mathrm{Si}=6.6-7.1$ a.p.f.u., $\mathrm{Al}^{\mathrm{IV}}=1.1-1.4$ a.p.f.u., $\mathrm{Al}^{\mathrm{VI}}=0.2-0.5$ a.p.f.u., $\mathrm{X}_{\mathrm{Mg}}=$ 0.55-0.70) surrounded by a light green rim (Amp $\mathrm{Am}_{2}$ metamorphic actinolite; $\mathrm{Si}=7.5-7.8, \mathrm{Al}^{\mathrm{IV}}=0.2-0.6$ a.p.f.u., $\mathrm{Al}^{\mathrm{Vl}}=0.0-0.15$ a.p.f.u., $\left.\mathrm{X}_{\mathrm{Mg}}=0.65-0.80\right)$. $\mathrm{A}$ very thin outermost rim of $\mathrm{Mg}$-hornblende $\left(\mathrm{Amp}_{3}\right.$ : $\mathrm{Si}=$ 7.2-7.4 a.p.f.u., $\mathrm{Al}^{\mathrm{IV}}=0.6-0.8$ a.p.f.u., $\mathrm{Al}^{\mathrm{VI}}=0.15-0.32$ a.p.f.u., $\mathrm{X}_{\mathrm{Mg}}=0.65-0.72$ ) is locally observed. Amphibole 
porphyroclasts are wrapped around by the pervasive mylonitic foliation (Fig. 2b,c), mainly defined by phengitic white mica ( $\mathrm{Si}=3.30-3.37$ a.p.f.u.) locally rimmed by muscovite ( $\mathrm{Si}=3.20-3.30$ a.p.f.u.), associated with chlorite $\left(\mathrm{X}_{\mathrm{Mg}}=0.65-0.67\right)$, quartz, albite $\left(\mathrm{Ab}_{96-100}\right)$ and epidote $\left(\mathrm{Ps}_{20-26}\right)$. Titanite, allanite and minor rutile occur as accessory minerals. Titanite is present both as large (100-200 $\mu \mathrm{m}$ in size) subhedral grains with common opaque intergrowths, interpreted as relics of the magmatic protolith, and as small $(<$ $10 \mu \mathrm{m}$ ) euhedral grains aligned in the main foliation, interpreted as metamorphic (Fig. 4a). Due to the very small size of the metamorphic titanite, only the larger magmatic grains have been dated.

Sample 06-17 (N36² $17^{\prime} 33.0^{\prime \prime} \mathrm{E} 76^{\circ} 34^{\prime} 58.2^{\prime \prime}-3870 \mathrm{~m}$ ) is a poorly deformed, hornblende + biotitebearing meta-diorite, still preserving the porphyric structure of the protolith (Fig. $2 \mathrm{~d}$ ). The deep-green, $\mathrm{mm}$ sized, magmatic hornblende $\left(\mathrm{Amp}_{1}\right.$ : magmatic Fe-hornblende; $\mathrm{Si}=6.5-7.3$ a.p.f.u., $\mathrm{Al}^{\mathrm{IV}}=$ 0.7-1.5 a.p.f.u., $\mathrm{Al}^{\mathrm{vI}}$ $=0.3-0.6$ a.p.f.u., $\left.\mathrm{X}_{\mathrm{Mg}}=0.34-0.50\right)$ is surrounded by a light green actinolitic rim ( $\mathrm{Amp}_{2}$ : metamorphic actinolite; $\mathrm{Si}=7.5-7.8, \mathrm{Al}^{\mathrm{IV}}=0.2-0.4$ a.p.f.u., $\mathrm{Al}^{\mathrm{VI}}=0.1-0.3$ a.p.f.u., $\mathrm{X}_{\mathrm{Mg}}=0.54-0.56$ ), in turn overgrown by a thin outermost rim of deep-green Fe-hornblende $\left(\mathrm{Amp}_{3}\right.$ : metamorphic Fe-hornblende; $\mathrm{Si}=$ 6.8-7.1 a.p.f.u., $A I^{\mathrm{IV}}=0.9-1.2$ a.p.f.u., $A \mathrm{I}^{\mathrm{VI}}=0.4-0.6$ a.p.f.u., $\mathrm{X}_{\mathrm{Mg}}=0.38-0.45$ ) (Fig. 2e,f). The former plagioclase phenocrysts of the protolith are replaced by $\mathrm{mm}$-sized, slightly zoned albite porphyroblasts (core: $A b_{97-100} ;$ rim: $A b_{95-97} \pm$ epidote $\left(\mathrm{Ps}_{25-30}\right)$, whereas magmatic biotite is replaced by fine-grained aggregates of greenish-brown biotite $\left(X_{\mathrm{Mg}}=0.40-0.42 ; \mathrm{Ti}=0.12-0.13\right.$ a.p.f.u. $)+$ epidote $\left(\mathrm{Ps}_{15-20}\right)+$ minor chlorite $\left(\mathrm{X}_{\mathrm{Mg}}=0.45-0.47\right)$ (Fig. 2f). Amphibole and albite porphyroblasts are set in a fine-grained matrix consisting of epidote + albite + minor quartz. Titanite occurs as large (up to $1 \mathrm{~mm}$ ) aggregates of fine-grained euhedral crystals (Fig. 4b-d), interpreted as relics of the magmatic protolith.

The observed mineral assemblages and compositions suggest that both samples 06-10 and 06-17 preserve the evidence of two distinct metamorphic events. The first event was more pervasive and was responsible for the growth of the actinolitic rim at the expenses of the magmatic hornblende in both samples, in equilibrium with albite + epidote + chlorite, \pm phengite (sample 06-10), \pm biotite (sample 06-17); the second event is marked by the appearance of the hornblende outermost rim in equilibrium with albite + epidote, \pm muscovite and chlorite in sample 06-10, and \pm biotite in sample 06-17. Equilibrium P-T conditions of the first metamorphic event were calculated for the assemblages Act $+\mathrm{Ab}+\mathrm{Phe}+\mathrm{Chl}+\mathrm{Ep}+$ $\mathrm{Qtz}+\mathrm{Rt}+$ Ttn of sample $06-10$, which resulted to be $482 \pm 20{ }^{\circ} \mathrm{C}, 11.5 \pm 1.2 \mathrm{kbar}$ (i.e. transition between greenschist- and blueschist-facies conditions; Fig. SM1); the second metamorphic event was constrained at $512 \pm 30^{\circ} \mathrm{C}, 4.5 \pm 1.7 \mathrm{kbar}$ (i.e. transition between greenschist- and amphibolite-facies conditions; Fig. SM1) using the $\mathrm{Hbl}+\mathrm{Ab}+\mathrm{Mu}+\mathrm{Chl}+\mathrm{Ep}+\mathrm{Qtz}+\mathrm{Rt}+$ Ttn assemblage of sample 06-10 (Table 2). Mineral assemblages of sample 06-17 do not define enough reactions for Average PT to work, but are nevertheless consistent with the results obtained from sample 06-10. Overall, these data suggest a clockwise P-T evolution characterized by relatively high-P peak conditions of $\sim 480^{\circ} \mathrm{C}, 11$ kbar followed by decompression coupled with moderate heating at $\sim 510^{\circ} \mathrm{C}, 4.5 \mathrm{kbar}$. 
5.1.2.2 Two-micas, garnet-bearing, metapelite (sample 06-115)

At its uppermost structural level, the Surukwat Complex mostly consists of metapelitic lithologies with minor intercalations of biotite-rich amphibolites and impure marbles likely derived from marl and limestone protoliths, respectively (Fig. 1d). Two of these metapelites, among which sample 06-115 studied in this work, have been petrologically investigated by Groppo and Rolfo (2008). Sample 06-115 is a twomicas, garnet-bearing micaschist consisting of quartz, muscovite, biotite, garnet, plagioclase $\left(\mathrm{An}_{5-18}\right)$, chlorite and accessory ilmenite (Fig. $2 \mathrm{~g}$ ). The main schistosity $\left(\mathrm{S}_{\mathrm{m}}\right)$ is defined by the alignment of muscovite ( $\mathrm{Si}=3.00-3.10$ a.p.f.u.), biotite $\left(\mathrm{X}_{\mathrm{Mg}}=0.42-0.50 ; \mathrm{Ti}=0.09-0.11\right.$ a.p.f.u. $)$ and ilmenite, and derives from the transposition of an earlier foliation $\left(\mathrm{S}_{\mathrm{m}-1}\right)$ defined by the same phases and still preserved in the microlithons (Fig. 2g). Garnet porphyroblasts (Alm ${ }_{71-75} \mathrm{Sps}_{12-15} \operatorname{Prp}_{7-9} \mathrm{Grs}_{2-3}$ ) are enveloped by the $S_{m}$ and overgrow the $S_{m-1}$, still preserved as an internal foliation (Fig. $2 \mathrm{~g}$ ). The outermost garnet rim is characterized by a sharp increase in $X_{M n}\left(A_{1 m} m_{69-71} \mathrm{Sps}_{20-21} \operatorname{Prp}_{6-7} \mathrm{Grs}_{2-3}\right)$, likely reflecting diffusional re-equilibration at the onset of the $S_{m}$ development. Late chlorite flakes $\left(X_{M g}=0.45-0.47\right)$ statically overgrow the $S_{m}$.

Monazite and rare xenotime are present as accessory minerals. Monazite occurs as subhedral grains within garnet and as elongate grains and clusters of grains aligned parallel to the dominant foliation in the matrix (Fig. 5).

The results of thermodynamic modeling (pseudosection approach: Groppo and Rolfo, 2008) suggest that the peak assemblage $(\mathrm{Grt}+\mathrm{Wm}+\mathrm{Bt}+\mathrm{PI}+\mathrm{Qz}+\mathrm{Ilm})$ grew at $580-600{ }^{\circ} \mathrm{C}, 8-9 \mathrm{kbar}$; consistent results are given by the Average PT method applied on the same assemblage $\left(645 \pm 26^{\circ} \mathrm{C}, 8.2 \pm 1.2 \mathrm{kbar}\right.$ ) (Table 2; Fig. SM1). Basing on the pseudosection results, Groppo and Rolfo, 2008 further constrained the main foliation development at ca. $500{ }^{\circ} \mathrm{C}, 5 \mathrm{kbar}$. Furthermore, combining the results obtained from sample 06-115 with those obtained from a second metapelite sample (06-117), the same authors inferred a steep and narrow anticlockwise P-T evolution for this portion of the Surukwat Complex (Fig. SM1).

\subsubsection{Aghil and Sughet magmatic bodies (samples 06-26, 06-108)}

Sample 06-26 (N36²11'02.4" E76³7'32.7" - $4905 \mathrm{~m}$ ) was collected from the Aghil Granodiorite body, in the proximity of the Aghil Pass. It is a biotite-bearing porphyritic granite crosscutting the main granodiorite, with perthitic K-feldspar crystals up to several centimeters in length (Fig. 2h). Plagioclase is zoned, with the Ca-richer core locally altered in sericite \pm saussurite, and a thin albite rim. Biotite is partially replaced by chlorite. Zircon and apatite are abundant among the accessory minerals and are often included in biotite. Sample 06-108 (N3604'08.3" E76²4'52.4'" - 3887 m) was collected from the Sughet Granodiorite body, near Sughet Jagal. It is a biotite-bearing granodiorite with poikilitic K-feldspar, zoned plagioclase partially altered in sericite, and brown biotite pervasively replaced by chlorite (Fig. 2i); apatite, zircon, and allanite occur as accessory minerals. 


\subsection{Geochronology results}

\subsubsection{Zircon}

Zircon from the Aghil (06-26) and Sughet (06-108) granodiorite bodies is euhedral with well-developed oscillatory zoning (Fig. 6). Sample 06-26 yielded reproducible ages and consistent REE patterns (Fig. 7a). Eight analyses define a weighted mean ${ }^{206} \mathrm{~Pb} /{ }^{238} \mathrm{U}$ age of $83 \pm 1 \mathrm{Ma}$ (MSWD=1.6) (Fig. 7a and Table 3). Results from sample 06-108 exhibit more scatter with one Proterozoic and 11 Cretaceous apparent ages. The Proterozoic age is interpreted as a xenocrystic core. Seven of the younger ages define a weighted mean ${ }^{206} \mathrm{~Pb} /{ }^{238} \mathrm{U}$ age of $102 \pm 1 \mathrm{Ma}$ (MSWD=0.9; Fig. 7b, Table 3). Two slightly older analyses are interpreted to reflect mixture of xenocrystic cores and younger magmatic zircon. The two younger analyses are inferred to record younger disturbance possibly associated with emplacement of the latest magmatic products of the Sughet granodiorite suite.

\subsubsection{Titanite}

Titanite ${ }^{206} \mathrm{~Pb} /{ }^{238} \mathrm{U}$ analyses from samples 06-10 and 06-17 (Surukwat Complex) generally contain low $\mathrm{U}$ (average $2 \mathrm{ppm} \mathrm{U}$ ) and high common $\mathrm{Pb}$ resulting in mixing array on Tera-Wasserburg plots (Fig. 8). Regression of analyses from sample 06-17 yields a well-defined 3-D isochron intercept age of $796 \pm 29 \mathrm{Ma}$ (MSWD=1.7), that is consistent with a weighted mean ${ }^{206} \mathrm{~Pb} /{ }^{238} \mathrm{U}$ age of $772 \pm 31 \mathrm{Ma}(\mathrm{MSWD}=2.4$ ) for the same data. All analyses from sample 06-10 (large titanite grains) are dominated by common $\mathrm{Pb}$, plotting near the upper intercept, with a regression that defines a lower intercept of $635 \pm 410 \mathrm{Ma}$, consistent with results of sample 06-17. Titanite ages from both samples are interpreted to record the protolith age of the orthogneiss bodies.

\subsubsection{Xenotime and monazite}

Xenotime analyses from sample 06-1 (Bazar Dara Slates Unit) define a weighted mean age of $174 \pm 11 \mathrm{Ma}$ $(M S W D=2.8)($ Fig. 9a, Table 6) and show a middle REE (MREE) enriched patterns (Fig. 9a) with strong depletion in light REE (LREE) characteristic of metamorphic xenotime (e.g. Aleinikoff et al., 2015). The xenotime grains occur in the matrix and have an ambiguous relationship with the dominant foliation. The xenotime ages are interpreted to record metamorphism at ca. $170 \mathrm{Ma}$. Two matrix monazite grains in sample 06-1 yield ${ }^{206} \mathrm{~Pb} /{ }^{238} \mathrm{U}$ ages of $153 \pm 3 \mathrm{Ma}$ and $161 \pm 4 \mathrm{Ma}$, which we interpret to be consistent with the ca. 170 Ma metamorphic age derived from xenotime, whereas a much younger metamorphic age of 35 $\pm 17 \mathrm{Ma}$ is recorded by a single matrix monazite.

In sample 06-115 (Surukwat Complex), xenotime is very rare. One grain of xenotime gave a ${ }^{204} \mathrm{~Pb}$ corrected ${ }^{206} \mathrm{~Pb} /{ }^{238} \mathrm{U}$ age of $165 \pm 6 \mathrm{Ma}$, which is consistent with the ca. $170 \mathrm{Ma}$ metamorphic age derived 
from xenotime in sample 06-1. Monazite in sample 06-115 dominantly occurs in the matrix but is locally preserved within garnet (Fig. 5). The monazite shows negative Eu anomalies and heavy REE depletion (Fig. 9b) consistent with growth in the presence of feldspar and garnet, respectively (e.g. Rubatto et al., 2013). Two monazite ${ }^{206} \mathrm{~Pb} /{ }^{238} \mathrm{U}$ age populations occur in this sample: (i) two monazite grains included in garnet gave ${ }^{206} \mathrm{~Pb} /{ }^{238} \mathrm{U}$ ages of $144 \pm 4 \mathrm{Ma}$ and $157 \pm 6 \mathrm{Ma}$ (Fig. 9b), thus defining a ca. $150 \mathrm{Ma}$ monazite generation; (ii) nine analyses from matrix monazite in sample 06-115 (Fig. 9b, Table 5) define a weighted mean age of $66 \pm 2$ Ma (MSWD = 1.1) (second monazite generation). The remaining grains record ages between 108 and $70 \mathrm{Ma}$ that are interpreted to reflect partial resetting of the older monazite formed originally at ca. $150 \mathrm{Ma}$. This interpretation is supported by core to rim Th zoning observed in grains that give $\mathrm{U} / \mathrm{Pb}$ ages $>70 \mathrm{Ma}$ (Fig. 5).

\section{Discussion}

\subsection{Pre-Cenozoic geodynamic evolution of the Aghil Range}

\subsubsection{The Surukwat Complex: a relic of Neoproterozoic basement with a possible late Palaeozoic cover} The U-Pb titanite ages obtained for the meta-granodiorite and meta-diorite (samples 06-10 and 06-17) from the Surukwat Complex tightly constrain the formation of the igneous protoliths at $796 \pm 29 \mathrm{Ma}$, i.e. during the Neoproterozoic.

Although not common, fragments of Neoproterozoic crystalline basement have been reported from different terranes in the central Tibetan Plateau (see Zhu et al., 2013 for a review). In the central Lhasa and Amdo terranes, U-Pb dating of zircons in gneissic rocks yielded 787-748 Ma (Nam Tso area: Hu et al., 2005) and 920-820 Ma (Amdo: Guynn et al., 2006, 2012) ages, respectively. Pre-Cambrian basement exposures are not reported so far from the Qiangtang terrane, the oldest basement rocks having been dated as Ordovician (Pullen et al., 2011; Zhao et al., 2014) or Cambro-Ordovician (Kapp et al., 2000). However, the existence of $\mathrm{a}>740 \mathrm{Ma}$ old basement in the Qiangtang terrane is suggested by Neoproterozoic inherited zircon ages obtained from an Early-Cretaceous granite from the Longmu Co area, western Tibet (Leloup et al., 2012). Neoproterozoic ages (ca. 865-825 Ma) have been also obtained for fragments of crystalline basement exposed in the southern part of the Songpan-Ganze terrane, in eastern Tibet (Roger and Calassou, 1997; Zhou et al., 2002, 2006a,b). Relicts of a possibly pre-Cambrian basement are also reported from the Karakorum (e.g. Le Fort et al., 1994; Zanchi and Gaetani, 2011), South Pamir (East Hindu Kush) (e.g. Zanchi and Gaetani, 2011) and Central Pamir (e.g. Schwab et al., 2004) terranes of the PamirKarakorum Range. All these data suggest that the different Gondwana-derived terranes which constitute the Tibetan Plateau and the Pamir-Karakorum Range are characterized by similar pre-Cambrian igneous basements, likely formed during the initial stages of Rodinia break-up (e.g. Guynn et al., 2012 and 
references therein). Our data allow the recognition of a new exposure of such Pre-Cambrian basement in the Surukwat Complex: this finding represents the westernmost occurrence, known so far, of Pre-Cambrian basement rocks in the Tibetan Plateau.

The Neoproterozoic basement of the Surukwat Complex is overlaid by a meta-sedimentary cover whose protoliths (i.e. conglomerate immediately overlying the igneous basement followed upward by sandstone and then mudstone with marl and limestone intercalations) are compatible with deposition in a passive continental margin setting (Fig. 1c). The age of these sedimentary protoliths is unknown, but it should be not younger than Triassic, because our data demonstrate that during Middle Jurassic these sediments were already metamorphosed (see below, Section 6.1.2). Basing on the strong similarities with late Palaeozoic meta-sedimentary sequences overlying the crystalline basement in the central Lhasa, Amdo and Qiangtang terranes (Kapp et al., 2000, 2003b, 2007; Leier et al., 2007; Pullen et al., 2008; Guynn et al., 2012), we suggest that the protoliths of the meta-sedimentary sequence exposed in the upper portion of the Surukwat Complex might be late Palaeozoic in age. In the absence of geochronological data constraining the age of the sedimentary protoliths, however, this hypothesis remains speculative, but is nevertheless consistent with the observed lithological associations. Our results thus suggest that the Surukwat Complex is a coherent slice of Neoproterozoic crystalline basement of dioritic to granodioritic and granitic composition, with a possibly late Palaeozoic sedimentary cover (Fig. 1c) deposited on a passive continental margin during the Gondwana break-up.

\subsubsection{The Middle Jurassic collision between the Bazar Dara Slates and the Surukwat Complex and the} Cimmerian Orogeny

The first tectono-metamorphic event experienced by the studied units is Middle Jurassic (ca. $170 \mathrm{Ma}$ ). This event is registered by xenotime and monazite in the two micas phyllite of the Bazar Dara Slates Unit (sample 06-1), and by rare xenotime grains in the garnet-bearing micaschist from the Surukwat Complex Unit (sample 06-115).

Evidence of a Late Triassic - Middle Jurassic orogenic event are widespread in both the Tibetan Plateau and the Pamir-Karakorum Range; this event, known as Cimmerian Orogeny (Sengör, 1984), led to the final amalgamation of the Cimmerian terranes (i.e. Qiangtang, Amdo, Central Pamir, South Pamir and Karakorum terranes) to the southern margin of Asia (i.e. Songpan-Ganze/Karakul Mazar and Kunlun terranes) through the complete closure of the Paleo-Tethys, and of the smaller Longmu Tso-Shuanghu, Rushan-Pshart and Wakan oceanic basins. The timing of each collision has been mostly determined basing on either stratigraphic or magmatic constraints, whereas metamorphic constraints have been less frequently used. Previous studies have shown that the final collision between each terrane occurred at slightly different ages from west to east. In the central Tibetan Plateau, the final collision of the Qiangtang terrane with the Songpan-Ganze and Kunlun terranes occurred during the Late Triassic - Early Jurassic (e.g. 
Dewey et al., 1988; Matte et al., 1996; Roger et al., 2003, 2010; Dai et al., 2013; Cao et al., 2015; Liu et al., 2015), and the amalgamation of South Qiangtang and North Qiangtang was broadly coeval, independently from the model chosen to explain the nature of the Central Qiangtang Metamorphic Belt (i.e. underthrust model vs intra-Qiangtang suture model, see section 2). In the Pamir-Karakorum Range the accretions of Central Pamir to Karakul Mazar (North Pamir) and of South Pamir to Central Pamir were broadly coeval at ca. $200 \mathrm{Ma}$, i.e. during the latest Triassic - earliest Jurassic (e.g. Gaetani et al., 1993; Zanchi et al., 2000, 2012; Zanchi and Gaetani, 2011; Angiolini et al., 2013; Robinson et al., 2015; Zanchetta et al., 2018), whereas the collision of Karakoram with South Pamir is supposed to be Late Early Jurassic (e.g. Searle and Tirrull, 1991; Gaetani et al., 1993; Angiolini et al., 2013).

In this framework, we therefore interpret the Middle Jurassic xenotime and monazite ages recorded by the two micas phyllite of the Bazar Dara Slates Unit (sample 06-1) to be related to the Cimmerian orogenic event, i.e. to the collision between the Bazar Dara Slates and the Surukwat Complex (Fig. 10); according to the petrologic results, this collisional event was responsible for a greenschist-facies (i.e. $\sim 320^{\circ} \mathrm{C}, 5 \mathrm{kbar}$ ) metamorphic overprint in the Bazar Dara Slates Unit (Fig. 11a,b). This is consistent with the stability field of both xenotime and monazite, that can grow in low-grade pelitic schists (Pan, 1997; Wing et al., 2003; Bollinger and Janots, 2006; Janots et al., 2006; Rasmussen et al., 2007; Krenn and Finger, 2007).

Due to the scarcity of xenotime in the metapelite of the Surukwat Complex (sample 06-115), the interpretation of its age and of the P-T conditions of its growth remain uncertain. It has been demonstrated that xenotime remains stable with increasing metamorphic grade in garnet-absent rocks, whereas it reacts out continuously as garnet grows, and is typically gone from the matrix assemblage in samples from the middle garnet zone (Spear and Pyle, 2002; Fitsimons et al., 2005). This constrains the growth of xenotime at temperatures below the first appearance of garnet (i.e. $\mathrm{T}<500^{\circ} \mathrm{C}$ according to the pseudosection modelling in Groppo and Rolfo, 2008) and explains why xenotime is so scarce in the garnet-bearing sample 06-115. The ca. $170 \mathrm{Ma}$ age obtained from the rare xenotime grains in this sample might be thus related to the same Cimmerian orogenic event registered by the Bazar Dara Slates Unit. An alternative hypothesis could be to correlate the ca. $170 \mathrm{Ma}$ age to the earliest stage of development of an accretionary complex on the southern margin of the Surukwat Complex (see below, section 5.1.3; Fig. 11a).

\subsubsection{The Late Jurassic formation of an accretionary prism on the southern margin of the Surukwat Complex} The Surukwat Complex experienced another significant tectono-metamorphic event during the Late Jurassic at ca. $150 \mathrm{Ma}$, responsible for the growth of a first generation of monazite in the metapelite sample 06-115 (two grains: $157 \pm 6 \mathrm{Ma}$ and $144 \pm 4 \mathrm{Ma}$ ). Microstructural observations show that this monazite generation is preserved in garnet, whereas in the matrix it is partially reset by the growth of a younger monazite generation (Fig. 5). It has been demonstrated that the first appearance of monazite in 
metapelitic rocks is strongly influenced by the bulk rock composition, particularly by the $\mathrm{CaO}$ content (e.g. Foster and Parrish, 2003; Wing et al., 2003) and the $\mathrm{CaO} / \mathrm{Na}_{2} \mathrm{O}$ ratio (e.g. Janots et al., 2008), and to a lesser extent by the $\mathrm{Al}_{2} \mathrm{O}_{3}$ content and $\mathrm{FeO} / \mathrm{MgO}$ ratio (e.g. Fitsimons et al., 2005). Janots et al. (2008) demonstrated that in metapelites with low $\mathrm{Ca} / \mathrm{Na}$ ratios (i.e. $\mathrm{CaO} / \mathrm{Na}_{2} \mathrm{O}<0.54$ ), monazite is formed through the complete breakdown of allanite at $\mathrm{T}>580^{\circ} \mathrm{C}$, whereas higher $\mathrm{Ca} / \mathrm{Na}$ ratios enhance the allanite stability towards higher temperatures. The $\mathrm{CaO} / \mathrm{Na}_{2} \mathrm{O}$ ratio of sample $06-115$ is 0.26 (Groppo and Rolfo, 2008), therefore it is likely that in this sample monazite grew at $\mathrm{T}>580^{\circ} \mathrm{C}$, through a reaction such as that proposed by Janots et al. (2008) (i.e. allanite + apatite + Al-Fe-Mg phases $1 \rightarrow$ monazite + anorthite + Al-Fe$\mathrm{Mg}$ phases2, with chlorite and garnet involved as Al-Fe-Mg phase1 and phase2, respectively). Garnet growth was modelled at $\sim 600^{\circ} \mathrm{C}, 9$ kbar (i.e. at peak conditions; Groppo and Rolfo, 2008), therefore we suggest that the ca. $150 \mathrm{Ma}$ registered by monazite grains included in garnet might be associated to the peak metamorphic event, and that monazite formation was nearly coeval with garnet growth (Fig. 11d), as also evidenced by its trace element pattern (Fig. 9b).

To interpret the geodynamic significance of this Late Jurassic metamorphic event, the apparently contrasting anticlockwise and clockwise P-T evolutions inferred for samples 06-115 and 06-10/17 should be considered (Groppo and Rolfo, 2008). Anticlockwise P-T paths at relatively high P-T conditions are characteristic of accretionary systems during the early stages of underflow, as suggested for the Franciscan melange (e.g. Platt, 1975; Cloos, 1985, 1986; Ernst, 1988; Krogh et al., 1994), the Coastal Cordillera of south-central Chile (e.g. Willner et al., 2004; Willner, 2005; Hyppolito et al., 2014) and, possibly, the North America Cordillera (Perchuck et al., 1999). In such geodynamic setting, rocks that were piled up earlier to the hot hanging wall of the subduction channel in the deepest part of the accretionary complex, were metamorphosed at higher temperatures for a given pressure (typically at albite-epidote amphibolite-facies conditions, transitional between high-pressure greenschist facies and eclogite facies; $~ 600-650{ }^{\circ} \mathrm{C}, 8-12$ kbar), compared to material subducted later (Perchuck et al., 1999). In the following accretionary stages, the hanging wall became progressively cooler and isotherms were continuously displaced to greater depth due to the continuous de-hydration of the later subducted material, thus implying that the early subducted rocks were exhumed at temperatures lower than those experienced during subduction, whereas the rocks involved later in the accretionary process recorded a normal clockwise P-T path (e.g. Willner et al., 2004; Willner, 2005; Hyppolito et al., 2014). Anticlockwise P-T metamorphic evolutions related to the inception of subduction are not commonly observed because of the extremely small areas affected by this type of metamorphism ( $\leq$ tens of $\mathrm{km}^{2}$, with thickness of few hundred meters: Wakabayashi, 2004). P-T conditions and evolutions recorded by the studied samples fit well with this geodynamic scenario (Fig. 10e-f, 11c-f). Moreover, it has been recently demonstrated that in similar tectonic settings, the accretionary process did not result in a chaotic mixing, but rather in the formation of a "pseudo"-coherent unit (Hyppolito et al., 
2014). This is also consistent with our observation that the Surukwat Complex consists of a tectonic intermingling of lithological units which nevertheless maintain their internal coherence.

To summarize, we suggest that during the Late Jurassic - Early/Middle Cretaceous, an accretionary prism developed on the southern margin of the Surukwat Complex (Fig. 10e-f). The first material involved in the subduction was a portion of the upper Palaeozoic (?) sedimentary cover (i.e. sample 06-115), which was subducted in a relatively hot environment at ca. $150 \mathrm{Ma}$ (Fig. 11c,d). The successive subduction of the thinned southern portion of the pre-Cambrian basement (i.e. samples 06-10 and 06-17) occurred in a cooler environment, during the early exhumation of the firstly subducted metasedimentary rocks (Fig. $11 \mathrm{e}, \mathrm{f})$.

\subsubsection{The Late Cretaceous collision between the Surukwat Complex and the Lhasa terrane}

The Surukwat Complex registered the last tectono-metamorphic event during the Late Cretaceous: this event is recorded in the metapelite sample 06-115 by the growth of monazite at $66 \pm 2 \mathrm{Ma}$. This second generation of monazite is ubiquitous in the matrix and appears in equilibrium with the main foliation, whose P-T conditions of formation were constrained by Groppo and Rolfo (2008) at $~ 500^{\circ} \mathrm{C}, 5 \mathrm{kbar}$.

Evidence of Late Cretaceous metamorphism has been reported from western Tibet and PamirKarakorum Range and are interpreted as the result of collision between the Lhasa and South Qiangtang terranes (western Tibet) and between the Kohistan-Ladakh and Karakorum terranes (Pamir-Karakorum), respectively. More specifically, in western Tibet, tight constrains on the time of this collision have been recently presented by Liu L. et al. (2017) and Liu D. et al. (2017) basing on the Late Cretaceous age of synorogenic magmatism. In the Pamir-Karakorum Range, the timing of collision between Kohistan-Ladakh and Karakourm has been constrained as Middle to Late Cretaceous basing on stratigraphic data (e.g. Gaetani et al., 1990b, 1993; Robinson et al., 2004; Zanchi and Gaetani, 2011; Gaetani, 2016), age of syn-orogenic magmatism (e.g. Fraser et al., 2001; Heuberger et al., 2007; Searle and Philipps, 2007; Searle, 2011) and metamorphic studies (e.g. Fraser et al., 2001; Streule et al., 2009; Searle, 2011). A complex and long-lasting history of tectonic and magmatic activity associated with the Kohistan-Karakorum suture zone, possibly extending up to Eocene time, is also proposed by Heuberger et al. (2007).

The $66 \pm 2$ Ma monazite age recorded by sample 06-115 can be therefore interpreted as the evidence of this collisional event (Fig. 10g, 11g-h). In this framework, the $83 \pm 1$ Ma zircon age obtained from the porphyric granite of the Aghil Granodiorite body (sample 06-26) is perfectly compatible with a subduction-related syn-orogenic magmatism preceding the final collision between the Surukwat Complex and the Lhasa terrane (Fig. 11g). It is worth noting that Liu L. et al. (2017) obtained very similar results (78$80 \mathrm{Ma}$ ) from granitic rocks collected from the same area. A similar interpretation can be extended also to the $102 \pm 1$ Ma zircon age obtained from the Sughet Granodiorite (sample 06-108): however, the Sughet 
Granodiorite intrusive body is located south of the Karakorum fault and it is therefore not directly correlated to the geodynamic history of the Surukwat Complex (see below, section 5.2).

\subsection{Solving the Tibet-Pamir-Karakorum geopuzzle}

The new field, petrological and geochronological data presented in this paper provide new insights toward a better understanding of the Tibet-Pamir-Karakorum geopuzzle, allowing to correlate the different terranes of Central Tibet with those of the Pamir-Karakorum Range on both sides of the Karakorum fault. We propose that (Fig. 12):

(1) the Bazar Dara Slates Unit might be the equivalent of the Sonpan-Ganze terrane of central Tibet, as already suggested by other authors (e.g. Gaetani et al., 1990a, 1991; Matte et al., 1996; Gaetani, 1997; Schwab et al., 2004; Rolfo et al., 2014) and can be correlated to the Karakul-Mazar terrane of the Pamir-Karakorum Range. Lithological and geochronological data from the Karakul-Mazar terrane of the eastern portion of Northern Pamir are especially similar to those described here for the Bazar Dara Slates Unit. These similarities include: (i) the occurrence of Triassic granitoids intruded in metasedimentary lithologies in both terranes (Robinson et al. 2007; Liu et al., 2015); (ii) the age of metamorphism (ranging from greenschist- to amphibolite-facies conditions) was constrained to be Early to Middle Jurassic (160-200 Ma) in the schists exposed along the Muztaghata massif of eastern Northern Pamir (Robinson et al., 2012) and is remarkably similar to the Middle Jurassic age of $170 \mathrm{Ma}$ registered by the studied sample 06-1, which also experienced greenschist-facies metamorphism. Robinson et al. (2012) interpreted this age as the timing of the collision between the Karakul-Mazar terrane and the Central Pamir during final closure of the Paleo-Tethys Ocean, as well as we interpret the Middle Jurassic age as dating the collision between the Bazar Dara Slates and the Surukwat Complex.

(2) the Surukwat Complex might be correlated to the southern margin of the South Qiangtang terrane of central Tibet (see also Gaetani et al., 1990a, 1991; Rolfo et al., 2014), and shows significant similarities with the tectono-stratigraphy and metamorphic evolution of the Amdo terrane. These similarities include: (i) the occurrence of a Neoproterozoic basement in both the Amdo and Surukwat Complex. In both cases this basement consists of felsic to intermediate gneisses derived from igneous protoliths and of a metasedimentary cover derived from late Palaeozoic sediments deposited in a passive margin setting (Guynn et al., 2006, 2012); (ii) widespread evidence of Jurassic metamorphism preceding the Lhasa-Qiangtang collision. Peak metamorphic conditions in the Amdo terrane vary from $\sim 600^{\circ} \mathrm{C}, 8 \mathrm{kbar}$ (remarkably similar to peak conditions estimated for sample $06-115$ ) to $\sim 700^{\circ} \mathrm{C}, 10 \mathrm{kbar}$, and metamorphic peak has been dated as Early Jurassic (ca. 178 Ma: Guynn et al., 2006, 2013). The Amdo terrane thus experienced peak metamorphism earlier than the Surukwat Complex (ca. $150 \mathrm{Ma}$ ), 
consistently with a diachronous activity of the Bangong-Nunjiang suture zone from east to west (Fig. $12 d-f)$.

Opposite to what preliminary suggested in Groppo and Rolfo (2008), the Surukwat Complex cannot be correlated to the Central Qiangtang Metamorphic Belt (CQMB), for three main reasons: (i) the CQMB mostly consists of a tectonic melange (e.g. Kapp et al., 2000, 2003a), whereas the Surukwat Complex is a coherent portion of an old basement with its original sedimentary cover still preserved; (ii) peak metamorphic conditions in some blocks of the CQMB reached blueschist and eclogite facies conditions (e.g. Kapp et al., 2000, 2003a; Zhang et al., 2006a,b, 2011; Pullen et al., 2008, 2011; Zhang and Tang, 2009; Zhai et al., 2011b; Zhao et al., 2014), thus reflecting a significantly different geothermal gradient with respect to the Surukwat Complex; (iii) the timing of metamorphism in the CQMB is Middle to Late Triassic (244-223 Ma: Pullen et al., 2008, 2011) whereas in the Surukwat Complex it is Late Jurassic (ca. $150 \mathrm{Ma})$.

(3) From a paleogeographic point of view, the Surukwat Complex occupies an intermediate position between the South Qiangtang terrane and the South Pamir terrane (e.g. Robinson, 2015, Chapman et al., 2018 and references therein), preserving different margins of the same micro-plate. The fundamental difference between the Surukwat Complex and South Pamir is that the latter does not show the evidence of Cretaceous metamorphism, having been "protected" from the collision with the Kohistan-Ladakh terrane by the interposed Karakorum terrane (Fig. 12g). Instead, the Karakorum terrane registered an important metamorphic and deformational event during the Late Cretaceous (between 83 and $62 \mathrm{Ma}$ ), that was interpreted as due to the collision with the Kohistan-Ladakh Arc (Fraser et al., 2001).

(4) In this framework, we propose that the non-metamorphic Shaksgam Sedimentary Belt and the Sughet Granodiorite body, now tectonically interposed between the Surukwat Complex and the Karakorum terrane, do not belong neither to the Surukwat Complex nor to the Karakorum terrane, but instead they are part of the South Pamir terrane (see also Robinson, 2009 and Gaetani and Leven, 2014). In other words, their actual location would not reflect their original position in pre-Cenozoic times, but it would be related to the offset effects of the Karakorum fault. This hypothesis is supported by both petrologic and geochronologic data showing that the Shaksgam Sedimentary Belt escaped the Late Cretaceous metamorphic and deformational event experienced by the Surukwat Complex and likely related to the collision with the Lhasa Terrane (Fig. 10g, 12g). Moreover, the $102 \pm 1 \mathrm{Ma}$ zircon age obtained from the Sughet Granodiorite body is perfectly compatible with the Late Cretaceous calcalkaline subduction-related magmatism responsible for the emplacement of large intrusive bodies in South Pamir as well as in the North Karakorum terrane (e.g. Karakorum Batholith, 106-95 Ma) (Debon et al., 1987; Fraser et al., 2001; Schwab et al., 2004; Zanchi and Gaetani, 2011), which has been related to a north-directed low-dipping subduction below Karakorum. 
9

\section{7} 11 1758 13 1759 15 1760 1761 1702 20

\section{Supplementary material}

Supplementary data to this article including (i) phase diagrams supporting the P-T evolution constrained for the studied samples (Fig. SM1) and (ii) the complete set of U-Pb geochronologic data for zircon (Table SM1a), titanite (Table SM1b), monazite (Table SM1c) and xenotime (Table SM1d) can be found online at:

\section{Acknowledgements}

This paper is dedicated to our late colleague and friend Maurizio Gaetani, who devoted most of his scientific career to the study of Karakorum and Pamir and provided constructive comments and suggestion on an earlier version of the manuscript. K. Horkley and J. Gilotti are thanked for providing electron microprobe composition maps of monazite. Threewo anonymous reviewers are acknowledged for their constructive comments which improved the manuscript.

Fieldwork of F.R. and C.G. was funded by the Italian National Research Council and the Italian Ministry of Foreign Affairs, in the framework of the Ev-K2-CNR Project. Laboratory work was funded by Compagnia di San Paolo (University of Torino, Call 1, Junior PI Grant: TO_Call1_2012_0068), University of Torino (Ricerca Locale, ex-60\% 2016, 2017 funds: ROLF_RILO_16_01, GROC_RILO_17_01), Italian Ministry of University and Research (PRIN 2015, Project $\left.n^{\circ}: 015 E C 9 P J 5\right)$. 


\section{References}

Aleinikoff, J.A., Schenck, W.S., Plank, M.O., Srogi, L.A., Fanning, C.M., Kamo, S.L., Bosbyshell, H., 2006. Deciphering igneous and metamorphic events in high-grade rocks of the Wilmington Complex, Delaware: Morphology, cathodoluminescence and backscattered electron zoning, and SHRIMP U-Pb geochronology of zircon and monazite. Geological Society of America Bulletin 118, 39-64.

Aleinikoff, J.N., Grauch, R.I., Mazdab, F.K., Kwak, L., Fanning, C.M., Kamo, S.L., 2012. Origin of an unusual monazite-xenotime gneiss, Hudson Highlands, New York: SHRIMP U-Pb geochronology and trace element geochemistry. American Journal of Science; 312, 723-765.

Aleinikoff, J.N., Lund, K., Fanning, C.M., 2015. SHRIMP U-Pb and REE data pertaining to the origins of xenotime in Belt Supergroup rocks: evidence for ages of deposition, hydrothermal alteration, and metamorphism. Canadian Journal of Earth Sciences 52, 722-745.

Aleinikoff, J.N., Wintsch, R.P., Tollo, R.P., Unruh, D.M., Fanning C.M., Schmitz, M.D., 2007. Ages and origins of rocks of the Killingworth dome, south-central Connecticut: Implications for the tectonic evolution of southern New England. American Journal of Science, 307, 63-118.

Allégre, C.J., Courtillot, V., Tapponnier, P., Hirn, A., Mattauer, M., Coulon, C., Jaeger, J.J., Achache, J., Scharer, U., Marcoux, J., Burg, J.P., Girardeau, J., Armijo, R., Gariepy, C., Gopel, C., Li, T.D., Xiao, X.C., Chang, C.F., Li, G.Q., Lin, B.Y., Teng, J.W., Wang, N.W., Chen, G.M., Han, T.L., Wang, X.B., Den, W.M., Sheng, H.B., Cao, Y.G., Zhou, J., Qiu, H.R., Bao, P.S., Wang, S.C., Wang, B.X., Zhou, Y.X., Ronghua, X., 1984. Structure and evolution of the Himalaya-Tibet orogenic belt. Nature 307, 17-22.

Angiolini, L., Zanchi, A., Zanchetta, S., Nicora, A., Vezzoli, G., 2013. The Cimmerian geopuzzle: new data from South Pamir. Terra Nova 25, 352-360.

Angiolini, L., Zanchi, A., Zanchetta, S., Nicora, A., Vuolo, O., Berra, F., Henderson, C., Malaspina, N., Rettori, R., Vachard, D., Vezzoli, G., 2015. From rift to drift in South Pamir (Tajikistan): Permian evolution of a Cimmerian terrane. Journal of Asian Earth Sciences 102, 146-169.

Barth, A.P., Wooden, J.L., 2006. Timing of magmatism following initial convergence at a passive margin, southwestern US Cordillera, and ages of lower crustal magma sources. Journal of Geology; 114, 231245.

Barth, A.P., Wooden, J.L., 2010. Coupled elemental and isotopic analyses of polygenetic zircons from granitic rocks by ion microprobe, with implications for melt evolution and the source of granitic magmas. Chemical Geology 277, 149-159.

Black, L.P., Kamo, S.L., Allen, C.M., Davis, D.W., Aleinikoff, J.N., Valley, J.W., Mundil, R., Campbell, I.H., Korsh, R.J., Williams, I.S., and Foudoulis, C., 2004. Improved ${ }^{206} \mathrm{~Pb} /{ }^{238} \mathrm{U}$ microprobe geochronology by monitoring of a trace-element-related matrix effect; SHRIMP, ID-TIMS, ELA-ICP-MS and oxygen isotope documentation for a series of zircon standards. Chemical Geology 205, 115-140. 
Bollinger, L., Janots, E., 2006. Evidence for Mio-Pliocene retrograde monazite in the Lesser Himalaya, far western Nepal. European Journal of Mineralogy 18, 289-297.

Burtman, V.S., Molnar, P., 1993. Geological and geophysical evidence for deep subduction of continental crust beneath the Pamir. Geological Society of America Special Paper 281, 1-76.

Cao, K., Wang, G.C., Bernet, M., van der Beek, P., Zhang, K.X., 2015. Exhumation history of the West Kunlun Mountains, northwestern Tibet: Evidence for a long-lived, rejuvenated orogen. Earth and Planetary Science Letters 432, 391-403.

Chapman, J.B., Robinson, A.C., Carrapa, B., Villarreal, D., Worthington, J., De Celes, P.G., Kapp, P., Gadoev, M., Oimahmadov, I., Gehrels, G., 2018. Cretaceous shortening and exhumation history of the South Pamir terrane. Lithosphere 10, 494-511.

Chen, M, Niu, F., Tromp, J., Lenardic, A., Lee, C.T.A., Cao, W., Ribeiro, J., 2017. Lithospheric foundering and underthrusting imaged beneath Tibet. Nature Communications 8, 15659.

Chung, S.L., Niu, Y., 2016. Recent advances on the tectonic and magmatic evolution of the Greater Tibetan Plateau: A special issue in honor of Prof. Guitang Pan. Lithos 245, 1-6.

Cloos, M., 1985. Thermal evolution of convergent plate margins: thermal modelling and reevaluation of isotopic Ar-ages for blueschist in the Franciscan Complex of California. Tectonics 4, 421-433.

Cloos, M., 1986. Blueschist in the Franciscan Complex of California: petrotectonic constraints on uplift mechanisms. In: Evans, B.W., Browns, E.H. (Eds.), Blueschist and Eclogites. Geological Society of America Memoir; 164, 77-93.

Coble, M.A., Vazquez, J., Barth, A.P., Wooden, J., Burns, D., Kylander-Clark, A., Jackson, S., and Vennari, C.E., 2018. Trace Element Characterization of MAD-559 Zircon Reference Material for Ion Microprobe Analysis, Geostandards and Geoanalytical Research,doi: 10.1111/ggr.12238 42, 481-497.

Coward, M.P., Kidd, W.S.F., Yun, P., Shackleton, R.M., Hu, Z., 1988. The Structure of the 1985 Tibet Geotraverse, Lhasa to Golmud. Philosophical Transactions of the Royal Society of London Series A Mathematical Physical and Engineering Sciences 327, 307-336.

Cross, A.J., Williams, I.S., 2018. SHRIMP U-Pb-Th xenotime $\left(\mathrm{YPO}_{4}\right)$ geochronology: A novel approach for the correction of SIMS matrix effects. Chemical Geology 484, 81-108.

Dai, J., Wang, C., Hourigan, J., Santosh, M., 2013. Multi-stage tectono-magmatic events of the Eastern Kunlun Range, northern Tibet: Insights from $\mathrm{U}-\mathrm{Pb}$ geochronology and (U-Th)/He thermochronology. Tectonophysics 599, 97-106.

Debon, F., Le Fort, P., Dautel, D., Sonet, J., Zimmermann, J.L., 1987. Granites of western Karakorum and northern Kohistan (Pakistan): A composite mid-Cretaceous to Upper Cenozoic magmatism. Lithos 20, 19-40.

Dewey, J.F., Shackleton, R.M., Chengfa, C., Yiyin, S., 1988. The tectonic evolution of the Tibetan Plateau. Philosophical Transactions of the Royal Society of London 327, 379-413. 
Ernst, W.G., 1988. Tectonic history of subduction zones inferred from retrograde blueschist P-T paths. Geology 16, 1081-1084.

Ferry, J.M., Watson, E.B., 2007. New thermodynamic models and revised calibrations for the Ti-in-zircon and Zr-in-rutile thermometers. Contributions to Mineralogy and Petrology 154, 429-437.

Fitzsimons, I.C.W., Kinny, P.D., Wetherley, S., Hollingsworth, D.A., 2005. Bulk chemical control on metamorphic monazite growth in pelitic schists and implications for U-Pb age data. Journal of Metamorphic Geology 23, 261-277.

Fletcher, I.R., McNaughton, N.J., Aleinikoff, J.N., Rasmussen, B., Kamo, S.L., 2004. Improved calibration procedures and new standards for $\mathrm{U}-\mathrm{Pb}$ and $\mathrm{Th}-\mathrm{Pb}$ dating of Phanerozoic xenotime by ion microprobe. Chemical Geology 209, 295-314.

Fletcher, I.R., McNaughton, N.J., Davis, W.J., Rasmussen, B. 2010. Matrix effects and calibration limitations in ion probe U-Pb and Th- $\mathrm{Pb}$ dating of monazite. Chemical Geology 270, 31-44.

Foster, G.L., Parrish, R.R., 2003. Metamorphic monazite and the generation of P-T-t paths. In: Vance, D., Müller, W., Villa, I.M. (Eds.), Geochronology: Linking the Isotopic Record with Petrology and Textures. Geological Society of London Special Publication, London 220, 25-47.

Fraser, J.E., Searle, M.P., Parrish, R.R., Nobel, S.R., 2001. Chronology of deformation, metamorphism, and magmatism in the southern Karakorum Mountains. Geological Society of America Bulletin 113, 14431455.

Gaetani, M., 1997. The Karakorum block in central Asia, from Ordovician to Cretaceous. Sedimentary Geology 109, 339-359.

Gaetani, M., 2016. Blank on the Geological Map. Rendiconti Lincei, Scienze Fisiche e Naturali 27, 181-195.

Gaetani, M., Garzanti, E., Jadoul, F., Nicora, A., Tintori, A., Pasini, M., Khan, K.S.A., 1990b. The north Karakorum side of the Central Asia geopuzzle. Geological Society of America Bulletin 102, 54-62.

Gaetani, M., Gosso, G., Pognante, U., 1990a. A geological transect from Kunlun to Karakorum. (Sinkiang, China): the western termination of the Tibetan Plateau. Preliminary note. Terra Nova 2, 23-30.

Gaetani, M., Gosso, G., Pognante, U., 1991. Geological transect from Kunlun to Karakorum. In: Desio, A. (Ed.), Geodesy, Geophysics and Geology of the Upper Shaksgam Valley (North East Karakorum) and South Sinkiang. Scientific Reports of the Italian Expedition to Karakorum 1988, Prof. A. Desio Leader. Ev K2 CNR, Milano, 99-190.

Gaetani, M., Jadoul, F., Erba, E., Garzanti, E., 1993. Jurassic and Cretaceous orogenic events in the North Karakorum: age constraints from sedimentary rocks. In: Treloar, P.J., Searle, M.P. (Eds.), Himalayan Tectonics. Geological Society of London Special Publication, London 74, 39-52. 
Gaetani, M., Leven, E.Y., 2014. The Permian succession of the Shaksgam Valley, Sinkiang (China). Italian Journal of Geosciences 133, 45-62.

Groppo, C., Rolfo, F., 2008. Counterclockwise P-T evolution of the Aghil Range: Metamorphic record of an accretionary melange between Kunlun and Karakorum (SW Sinkiang, China). Lithos 105, 365-378.

Guynn J., Tropper P., Kapp P., Gehrels G.E., 2013. Metamorphism of the Amdo metamorphic complex, Tibet: implications for the Jurassic tectonic evolution of the Bangong suture zone. Journal of metamorphic Geology 31, 705-727.

Guynn, J., Kapp, P., Gehrels, G., Ding, L., 2012. U-Pb geochronology 1 of basement rocks in central Tibet and paleogeographic implications. Journal of Asian Earth Sciences 43, 23-50.

Guynn, J.H., Kapp, P., Pullen, A., Heizler, M., Gehrels, G., Ding, L., 2006. Tibetan basement rocks near Amdo reveal "missing" Mesozoic tectonism along the Bangong suture, central Tibet. Geology 34, 505-508.

Harris, N.B.W., Xu, R.H., Lewis, C.L., Jin, C.W., 1988. Plutonic rocks of the 1985 Tibet Geotraverse, Lhasa to Golmud. Philosophical Transactions of the Royal Society of London Series A - Mathematical Physical and Engineering Sciences 327, 145-168.

Hayden, L.A., Watson, E.B., 2007. Rutile saturation in hydrous siliceous melts and its bearing on Tithermometry of quartz and zircon. Earth and Planetary Science Letters 258, 561-568.

Heuberger, S., Schaltegger, U., Burg, J.P., Villa, I.M., Frank, M., Dawood, H., Hussain, S., Zanchi, A., 2007. Age and isotopic constraints on magmatism along the Karakorum-Kohistan Suture Zone, NW Pakistan: evidence for subduction and continued convergence after India-Asia collision. Swiss Journal of Geosciences 100, 85-107.

Hildebrand, P.R., Nobel, S.R., Searle, M.P., Waters, D.J., Parrish, R.R., 2001. Old origin for an active mountain range: geology and geochronology of the eastern Hindu Kush, Pakistan. Geological Society of America Bulletin 113, 625-639.

Holland, T.J.B., Powell, R., 1998. An internally consistent thermodynamic data set for phases of petrologic interest. Journal of Metamorphic Geology 16, 309-343.

Hu, D.G., Wu, Z.H., Jiang, W., Shi, Y.R., Ye, P.S., Liu, Q.S., 2005. SHRIMP zircon U-Pb age and Nd isotopic study on the Nyainqêntanglha Group in Tibet. Science in China (Series D: Earth Sciences) 48, 1377-1386.

Hyppolito, T., Garcia-Gasco, A., Juliani, C., Meira, V.T., Hall, C., 2014. Late Paleozoic onset of subduction and exhumation at the western margin of Gondwana (Chilenia Terrane): Counterclockwise P-T paths and timing of metamorphism of deep-seated garnet-mica schist and amphibolite of Punta Sirena, Coastal Accretionary Complex, central Chile (34 S). Lithos 206-207, 409-434.

Ireland, T.R., Williams, I.S., 2003. Considerations in zircon geochronology by SIMS. In: Hanchar, J.M., Hoskin, W.O. (Eds.), Reviews in Mineralogy and Geochemistry 53, 215-241. 
Janots, E., Engi, M., Berger, A., Allaz, J., Schwarz, J.O., Spandler, C., 2008. Prograde metamorphic sequence of REE minerals in pelitic rocks of the Central Alps: implications for allanite-monazite-xenotime phase relations from 250 to $610^{\circ} \mathrm{C}$. Journal of metamorphic Geology 26, 509-526.

Janots, E., Negro, F., Brunet, F., Goffe', B., Engi, M. and Bouybaouene, M. L., 2006. Evolution of the REE mineralogy in HP-LT metapelites of the Sebtide complex, Rif, Morocco: monazite stability and geochronology. Lithos 87, 214-234.

Kapp, P., 2001. Blueschist-bearing metamorphic core complexes in the Qiangtang block reveal deep crustal structure of northern Tibet. Comment and Reply. Geology 29, 91.

Kapp, P., DeCelles, P.G., Gehrels, G.E., Heizler, M., Lin, D., 2007. Geological records of the Lhasa-Qiangtang and Indo-Asian collisions in the Nima area of central Tibet. Geological Society of America Bulletin 119, 917-933.

Kapp, P., Murphy, M.A., Yin, A., Harrison, M., 2003b. Mesozoic and Cenozoic tectonic evolution of the Shiquanhe area of western Tibet. Tectonics 22, 1029.

Kapp, P., Yin, A., Harrison, T.M., Ding, L., 2005. Cretaceous-Tertiary shortening, basin development, and volcanism in central Tibet. Geological Society of America Bulletin 117, 865-878.

Kapp, P., Yin, A., Manning, C.E., Harrison, T.M., Taylor, M., 2003a. Tectonic evolution of the early Mesozoic blueschist-bearing Qiangtang metamorphic belt, central Tibet. Tectonics 22, 1043.

Kapp, P., Yin, A., Manning, C.E., Murphy, M., Harrison, T.M., Spurlin, M., 2000. Blueschist-bearing metamorphic core complexes in the Qiangtang block reveal deep crustal structure of northern Tibet. Geology 28, 19-22.

Krenn, E., Finger, F., 2007. Formation of monazite and rhabdophane at the expense of allanite during Alpine low temperature retrogression of metapelitic basement rocks from Crete, Greece: Microprobe data and geochronological implications. Lithos 95, 130-147.

Krogh, E.J., Oh, C.W., Liou, J.G., 1994. Polyphase and anticlockwise P-T evolution for Franciscan eclogites and blueschists from Jenner, California, USA. Journal of Metamorphic Geology 18, 211-219.

Lacassin, R., Valli, F., Arnaud, N., Leloup, P.H., Paquette, J.L., Haibing, L., Tapponnier, P., Chevalier, M.L., Guillot, S., Maheo, G., Zhiqin, X., 2004. Large-scale geometry, offset and kinematic evolution of the Karakorum fault, Tibet. Earth and Planetary Science Letters 219, 255-269.

Le Fort, P., Tongiorgi, M., Gaetani, M., 1994. Discovery of a crystalline basement and Early Ordovician marine transgression in the Karakorum mountain range, Pakistan. Geology 22, 941-944.

Leeder, M.R., Smith, A.B., Yin, J.X., 1988. Sedimentology, paleoecology and palaeoenvironmental evolution of the 1985 Lhasa to Golmud Geotraverse. Philosophical Transactions of the Royal Society of London Series A, Mathematical Physical and Engineering Sciences 327, 107-143.

Leier, A.L., Kapp, P., Gehrels, G.E., DeCelles, P.G., 2007. Detrital zircon geochronology of CarboniferousCretaceous strata in the Lhasa terrane, Southern Tibet. Basin Research 19, 361-378. 
Leloup, P.H., Arnaud, N.O., Maheo, G., Paquette, J.L., Guillot, S., Valli, F., Li, H., Xu, Z., Lacassin, R., Tapponnier, P., 2012. Successive deformation episodes along the Lungmu Co zone, west-central Tibet. Gondwana Research 21, 37-52.

Leloup, P.H., Boutinnet, E., Davis, W.J., Hattori, K., 2011. Long-lasting intracontinental strike-slip faulting: new evidence from the Karakorum shear zone in the Himalayas. Terra Nova 23, 92-99.

Lemennicier, Y., Le Fort, P., Lombardo, B., Pêcher, A., Rolfo, F. 1996. Tectonometamorphic evolution of the central Karakorum (Baltistan - northern Pakistan). Tectonophysics 260, 119-143.

Liang, X., Wang, G., Yuan, G., Liu, Y., 2012. Structural sequence and geochronology of the Qomo Ri accretionary complex, Central Qiangtang, Tibet: implications for the Late Triassic subduction of the Paleo-Tethys Ocean. Gondwana Research 22, 470-481.

Liu, D., Shi, R., Ding, L., Huang, Q., Zhang, X., Yue, Y., Zhang, L., 2017. Zircon U-Pb age and Hf isotopic compositions of Mesozoic granitoids in southern Qiangtang, Tibet: Implications for the subduction of the Bangong-Nujiang Tethyan Ocean. Gondwana Research 41, 157-1720.

Liu, L., Hou, M., Chen, Y., Tang, H., Xiao, C., 2017. Late Cretaceous granitoids in Karakorum, northwest Tibet: petrogenesis and tectonic implications, International Geology Review 59, 151-165.

Liu, Y., Santosh, M., Zhao, Z.B., Niu, W.C., Wang, G.H., 2011. Evidence for palaeo-Tethyan oceanic subduction within central Qiangtang, northern Tibet. Lithos 127, 39-53.

Liu, Z., Jiang, Y., Jia, R., Zhao, P., Zhou, Q., 2015. Origin of Late Triassic high-K calc-alkaline granitoids and their potassic microgranular enclaves from the western Tibet Plateau, northwest China: implications for Paleo-Tethys evolution. Gondwana Research 27, 326-341.

Ludwig, K.R., 2009. Squid 2, A user's manual. Berkeley Geochronology Center Special Publication No. 5, p. 110.

Ludwig, K.R., 2012. Isoplot 3.75, a geochronological toolkit for Excel. Berkeley Geochronology Center Special Publication No. 5, p. 75.

Matte, P., Tapponnier, P., Arnaud, N., Bourjot, L., Avouac, J.P., Vidal, P., Liu, Q., Pan, Y., Wang, Y., 1996. Tectonics of Western Tibet, between the Tarim and the Indus. Earth and Planetary Science Letters 142, 311-330.

McDonough, W.F., Sun, S.S., 1995. The composition of the Earth. Chemical Geology 120, 223-253.

Murphy, M.A., Yin, A., Harrison, T.M., Dürr, S.B., Chen, Z., Ryerson, F.J., Kidd, W.S.F., Wang, X., Zhou, X., 1997. Did the Indo-Asian collision alone create the Tibetan plateau? Geology 25, 719-722.

Pan, G.T, Ding, J., Yao, D., Wang, L., 2004. Geological Map of the Qinghai-Xizang (Tibet) Plateau and Adjacent Areas. Chengdu Cartographic Publishing House, Chengdu.

Pan, G.T., Wang, L.Q., Li, R.S., Yuan, S.H., Ji, W.H., Yin, F.G., Zhang, W.P., Wang, B.D., 2012. Tectonic evolution of the Qinghai-Tibet Plateau. Journal of Asian Earth Sciences 53, 3-14. 
Pan, Y.M., 1997. Zircon- and monazite-forming metamorphic reactions at Manitouwadge, Ontario. Canadian Mineralogist 35, 105-118.

Perchuk, A., Philippot, P., Erdmer, P., Fialin, M., 1999. Rates of thermal equilibration at the onset of subduction deduced from diffusion modelling of eclogitic garnets, Yukon-Tanana terrane, Canada. Geology 27, 531-534.

Phillips, R.J., 2008. Geological map of the Karakoram fault zone, Eastern Karakoram, Ladakh, NW Himalaya. Journal of Maps 4, 21-37.

Phillips, R.J., Parrish, R.R., Searle, M.P., 2004. Age constraints on ductile deformation and long-term slip rates along the Karakoram fault zone, Ladakh. Earth and Planetary Science Letters 226, 305-319.

Platt, J.P., 1975. Metamorphism and deformational processes in the Franciscan Complex, California. Some insights from the Catalina schists terrane. Geological Society of America Bullettin 86, 1337-1347.

Pouchou, J.L., Pichoir, F., 1988. Determination of mass absorption coefficients for soft Xrays by use of the electron microprobe. Microbeam Analysis. San Francisco Press, pp. 319-324.

Powell, R., Holland, T.J.B., 1994. Optimal geothermometry and geobarometry. American Mineralogist 79, 120-133.

Pullen, A., Kapp, P., Gehrels, G.E., Ding, L., Zhang, Q., 2011. Metamorphic rocks in central Tibet: lateral variations and implications for crustal structure. Geological Society of America Bulletin 123, 585-600.

Pullen, A., Kapp, P., Gehrels, G.E., Vervoort, J.D., Lin, D., 2008. Triassic continental subduction in central Tibet and Mediterranean-style closure of the Paleo-Tethys Ocean. Geology 36, 351-354.

Rasmussen, B., Fletcher, I.R., Muhling, J.R., 2007. In situ U-Pb dating and element mapping of three generations of monazite: unravelling cryptic tectonothermal events in low-grade terranes. Geochimica et Cosmochimica Acta 71, 670-690.

Robinson, A.C., 2009. Geologic offsets across the northern Karakorum fault: implications for its role and terrane correlations in the western Himalayan- Tibetan orogen. Earth and Planetary Science Letters 279, 123-130.

Robinson, A.C., 2015. Mesozoic tectonics of the Gondwanan terranes of the pamir plateau. Journal of Asian Earth Sciences 102, 170-179.

Robinson, A.C., Ducea, M., Lapen, T.J., 2012. Detrital zircon and isotopic constraints on the crustal architecture and tectonic evolution of the northeastern Pamir. Tectonics 31, TC2016.

Robinson, A.C., Yin, A., Manning, C.E., Harrison, M., Zhang, S.H., Wang, X.F., 2007. Cenozoic evolution of the eastern Pamir: Implications for strain-accommodation mechanisms at the western end of the Himalayan-Tibetan orogeny. Geological Society of America Bulletin 119, 882-896.

Robinson, A.C., Yin, A., Manning, C.E., Harrison, T.M., Zhang, S.-H., Wang, X.-F., 2004. Tectonic evolution of the northeastern Pamir: constraints from the northern portion of the Cenozoic Kongur Shan extensional system. Geological Society of America Bulletin 116, 953-974. 
Roger, F., Arnaud, N., Gilder, S., Tapponnier, P., Jolivet, M., Brunel, M., Malavieille, J., Xu, Z., 2003. Geochronological and geochemical constraints on Mesozoic suturing in East Central Tibet. Tectonics 22, 1037.

Roger, F., Calassou, S., 1997. U-Pb geochronology on zircon and isotopic geochemistry (Pb, Sr, $\mathrm{Nd}$ ) of basement in the Songpan-Garze fold belt (China). Comptes Rendus de I'Académie des Sciences Paris $324,819-826$.

Roger, F., Jolivet, M., Malavieille, J., 2010. The tectonic evolution of the Songpan-Garzê (North Tibet) and adjacent areas from Proterozoic to Present: a synthesis. Journal of Asian Earth Sciences 39, 254-269.

Rolfo, F., Groppo, C., Gaetani, M., 2014. A geological cross-section north of Karakorum, from Yarkand to K2. In: Montomoli, C., Carosi, R., Law, R., Singh, S., Ra,i S.M. (Eds.), Geological field trips in the Himalaya, Karakoram and Tibet. Journal of the Virtual Explorer, Electronic Edition, 47, paper 1.

Rolfo, F., Lombardo, B., Compagnoni, R., Le Fort, P., Lemennicier, Y., Pêcher, A., 1997. Geology and Metamorphism of the Ladakh Terrane and Shyok Suture Zone in the Chogo Lungma - Turmik area (northern Pakistan). Geodinamica Acta 10/5, 251-270.

Rubatto, D., Chakraborty, S., Dasgupta, S., 2013. Timescales of crustal melting in the Higher Himalayan Crystallines (Sikkim, Eastern Himalaya) inferred from trace element-constrained monazite and zircon chronology. Contribution to Mineralogy and Petrology 165, 349-372.

Schoene, B., Borwing, S.A., 2006. U-Pb systematics of the McClure Mountain syenite: thermochronological constraints on the age of the ${ }^{40} \mathrm{Ar}^{-39} \mathrm{Ar}$ standard MMhb. Contributions to Mineralogy and Petrology 151, $615-630$

Schwab, M., Ratschbacher, L., Siebel, W., McWilliams, M., Minaev, V., Lutkov, V., Chen, F., Stanek, K., Nelson, B., Frisch, W., Wooden, J.L., 2004. Assembly of the Pamirs: Age and origin of magmatic belts from the southern Tien Shan to the southern Pamirs and their relation to Tibet. Tectonics 23, TC4002.

Searle, M.P., 2011. Geological evolution of the Karakoram Ranges. Italian Journal of Geosciences 130, 147159.

Searle, M.P., Elliott J.R., Phillips R.J, Chung S.L., 2011. Crustal-lithospheric structure and continental extrusion of Tibet. Journal of the Geological Society of London 168, 633-672.

Searle, M.P., Parrish, R.R., Thow, A.V., Noble, S.R., Phillips, R.J. and Waters, D.J. 2010. Anatomy, age and evolution of a collisional mountain belt: the Baltoro granite batholith and Karakoram Metamorphic complex, Pakistani Karakoram. Journal of the Geological Society of London 167, 183-202.

Searle, M.P., Phillips, R.J., 2007. Relationships between right-lateral shear along the Karakoram fault and metamorphism, magmatism, exhumation and uplift: evidence from the K2-Gasherbrum-Pangong ranges, north Pakistan and Ladakh. Journal of Geological Society of London 164, 439-450.

Searle, M.P., Tirrul, R. 1991. Structural and thermal evolution of the Karakoram crust. Journal of the Geological Society of London 148, 65-82. 
Sengör, A.M.C., 1979. Mid-Mesozoic closure of Tethys and its implications. Nature 279, 590-593.

Sengör, A.M.C., 1984. The Cimmeride orogenic system and the tectonics of Eurasia. Geological Society of America Special Paper 195, 1-82.

Sengör, A.M.C., 1987. Tectonics of the tethysides: orogenic collage development in a collisional setting. Annual Review of Earth and Planetary Sciences 15, 213-244.

Shi, R.D., 2007. SHRIMP dating of the Bangong Lake SSZ-type ophiolite: constraints on the closure time of ocean in the Bangong Lake-Nujiang River, northwestern Tibet. Chinese Science Bulletin 52, 936-941.

Shi, R.D., Yang, J.S., Xu, Z.Q., Qi, X.X., 2004. Discovery of the boninite series volcanic rocks in the Bangong Lake ophiolite mélange, western Tibet, and its tectonic implications. Chinese Science Bulletin 49, $1272-$ 1278.

Spear, F.S., Pyle, J.M., 2002. Apatite, monazite, and xenotime in metamorphic rocks. In: Kohn, M.J., Rakovan, J., Hughes, J.M. (Eds.), Phosphates: Geochemical, Geobiological, and Materials Importance. Reviews in Mineralogy and Geochemistry, 48. Mineralogical Society of America, Washington, D.C., pp. 293-335.

Stacey, J.S., Kramers, J.D., 1975. Approximation of terrestrial lead isotope evolution by a two-stage model.Earth and Planetary Science Letters 26, 207-221.

Streule, M.J., Phillips, R.J., Searle, M.P., Waters, D.J., Horstwood, M.S.A., 2009. Evolution and chronology of the Pangong Metamorphic Complex adjacent to the Karakoram Fault, Ladakh: constraints from thermobarometry, metamorphic modelling and U-Pb geochronology. Journal of Geological Society of London 166, 919-932.

Upadhyay, R., Rai, J., Sinha, A.K., 2005. New record of Bathonian-Callovian calcareous nannofossils in the eastern Karakoram block: a possible clue to understanding the dextral offset along the Karakoram Fault. Terra Nova 17, 149-157.

Valli, F., Leloup, P.H., Paquette, J.-L., Arnaud, N., Li, H., Tapponnier, P., Lacassin, R., Guillot, S., Liu, D., Deloule, E., Xu, Z., Mahéo, G., 2008. New U/Pb constraints on timing of shearing and long-term slip-rate on the Karakorum fault. Tectonics 27 (5), TC5007.

Wakabayashi, J., 2004. Tectonic mechanisms associated with P-T paths of regional metamorphism: alternatives to single-cycle thrusting and heating. Tectonophysics 392, 193-218.

Watson, E.B., Harrison, T.M., 2005. Zircon thermometer reveals minimum melting conditions on earliest Earth. Science 308, 841-844.

Williams, I.S., 1998. U-Pb by ion microprobe. In: McKibben, M.A., Shanks, W.C. and Ridley, W.I. (Eds.), Applications of microanalytical techniques to understanding mineralizing processes. Society of Economic Geologists, Reviews in Economic Geology 7, 1-35.

Willner, A.P., 2005. Pressure-Temperature Evolution of a Late Palaeozoic Paired Metamorphic Belt in North-Central Chile $\left(34^{\circ}-35^{\circ} 30^{\prime} \mathrm{S}\right)$. Journal of Petrology 46, 105-1833. 
Willner, A.P., Glodny, J., Gerya, T.V., Godoy, E., Massonne, H.J., 2004. A counterclockwise PTt path of high pressure/low temperature rocks from Coastal Cordillera accretionary complex of south-central Chile: constraints for the earliest stage of subduction mass flow. Lithos 75, 283-310.

Wing, B.A., Ferry, J.M., Harrison, T.M., 2003. Prograde destruction and formation of monazite and allanite during contact and regional metamorphism of pelites: petrology and geochronology. Contributions to Mineralogy and Petrology 145, 228-250.

Xiao, W.J., Windley, B.F., Chen, H.L., Zhang, G.C., Li, J.L., 2002. Carboniferous-Triassic subduction and accretion in the western Kunlun, China: implications for the collisional and accretionary tectonics of the northern Tibetan Plateau. Geology 30, 295-298.

Xu, R.H., Schaerer, U., Allegre, C.J., 1985. Magmatism and metamorphism in the Lhasa Block (Tibet); a geochronological study. Journal of Geology 93, 41-57.

Yang, Y., Guo, Z., Luo, Y., 2017. Middle-Jurassic tectonostratigraphic evolution of Central Asia, implications for the collision of the Karakoram-Lhasa Block with Asia. Earth Science Reviews 166, 83-110.

Yin, A., Harrison, T.M., 2000. Geologic evolution of the Himalayan-Tibetan orogen. Annual Review of Earth Planetary Science 28, 211-280.

Zanchetta, S., Worthington, J., Angiolini, L., Leven, E.J., Villa, I.M., Zanchi, A., 2018. The Bashgumbaz Complex (Tajikistan): Arc obduction in the Cimmerian orogeny of the Pamir. Gondwana Research 57, 170-190.

Zanchi, A., Fürsich, F.T., Santosh, M., 2015. Cimmerian terranes: Preface. Journal of Asian Earth Sciences $102,1-3$.

Zanchi, A., Gaetani, M., 2011. The geology of the Karakoram range, Pakistan: the new 1:100,000 geological map of Central-Western Karakoram. Italian Journal of Geosciences 130, 161-262.

Zanchi, A., Poli, S., Fumagalli, P., Gaetani, M., 2000. Mantle exhumation along the Tirich Mir Fault Zone, NW Pakistan: pre-mid-Cretaceous accretion of the Karakoram terrane to the Asian margin. In: Khan, M.A., Treloar, P.J., Searle, M.P., Jan, M.Q. (Eds.), Tectonics of the Nanga Parbat Syntaxis and the Western Himalaya. Geological Society of London. Special Publications, London 170, pp-219-236.

Zanchi, A., Zanchetta, S., Angiolini, L., Vezzoli, G., 2012. Is SE-Pamir a Cimmerian Block? Rendiconti Online Società Geologica Italiana 22, 239-242.

Zeng, M., Zhang, X., Cao, H., Ettensohn, F.R., Cheng, W., Lang, X., 2016. Late Triassic initial subduction of the Bangong-Nujiang Ocean beneath Qiangtang revealed: stratigraphic and geochronological evidence from Gaize, Tibet. Basin Research 28, 147-157.

Zhai, Q.G., Jahn, B.M., Wang, J., Su, L., Mo, X.X., Wang, K.L., Tang, S.H., Lee, H.Y., 2013. The Carboniferous ophiolite in the middle of the Qiangtang terrane, Northern Tibet: SHRIMP U-Pb dating, geochemical and Sr-Nd-Hf isotopic characteristics. Lithos 168, 186-199. 
Zhai, Q.G., Jahn, B.M., Zhang, R.Y., Wang, J., Su, L., 2011a. Triassic subduction of the Paleo-Tethys in northern Tibet, China: evidence from the geochemical and isotopic characteristics of eclogites and blueschists of the Qiangtang block. Journal of Asian Earth Sciences 42, 1356-1370.

Zhai, Q.G., Zhang, R.Y., Jahn, B.M., Li, C., Song, S.G., Wang, J., 2011b. Triassic eclogites from central Qiangtang, northern Tibet, China: petrology, geochronology and metamorphic P-T path. Lithos 125, 173-189.

Zhang K.J., Zhang Y.X., Tang X.C., Xie Y.W., Sha S.L., Peng X.J., 2008. First report of eclogites from central Tibet, China: evidence for ultradeep continental subduction prior to the Cenozoic India-Asian collision. Terra Nova 20, 302-308.

Zhang, K.J., 2001. Blueschist-bearing metamorphic core complexes in the Qiangtang block reveal deep crustal structure of northern Tibet: comment and reply. Geology 29, 90.

Zhang, K.J., Cai, J.X., Zhang, Y.X., Zhao, T.P., 2006a. Eclogites from central Qiangtang, northern Tibet (China) and tectonic implications. Earth and Planetary Science Letters 245, 722-729.

Zhang, K.J., Tang, X.C., 2009. Eclogites in the interior of the Tibetan plateau and their geodynamic implications. Chinese Science Bulletin 54, 2556-2567.

Zhang, K.J., Tang, X.C., Wang, Y., Zhang, Y.X., 2011. Geochronology, geochemistry, and Nd isotopes of early Mesozoic bimodal volcanism in northern Tibet, western China: constraints on the exhumation of the central Qiangtang metamorphic belt. Lithos 121, 167-175.

Zhang, K.J., Zhang, Y.X., Li, B., Zhu, Y.T., Wei, R.Z., 2006b. The blueschist-bearing Qiangtang metamorphic belt (northern Tibet, China) as an in situ suture zone: evidence from geochemical comparison with the Jinsa suture. Geology 34, 493-496.

Zhang, K.J., Zhang, Y.X., Tang, X.C., Xia, B., 2012. Late Mesozoic tectonic evolution and growth of the Tibetan plateau prior to the Indo-Asian collision. Earth Science Reviews 114, 236-249.

Zhang, Y., Niu, Y., Hu, Y., Liu, J., Ye, L., Kong, J., Duan, M., 2016. The syncollisional granitoid magmatism and continental crust growth in the West Kunlun Orogen, China - Evidence from geochronology and geochemistry of the Arkarz pluton. Lithos 245, 191-204.

Zhang, Z., Ding, L., Zhao, Z., Santosh, M., 2017. Tectonic evolution and dynamics of the Tibetan Plateau. Gondwana Research 41, 1-8.

Zhang, Z., Dong, X., Liu, F., Lin, Y., Yan, R., He, Z., Santosh, M., 2012b. The making of Gondwana: Discovery of 650Ma HP granulites from the North Lhasa, Tibet. Precambrian Research 212-213, 107-116.

Zhang, Z., Dong, X., Liu, F., Lin, Y., Yan, R., Santosh, M., 2012a. Tectonic Evolution of the Amdo Terrane, Central Tibet: Petrochemistry and Zircon U-Pb Geochronology. The Journal of Geology 120, 431-451. Zhang, Z., Dong, X., Santosh, M., Zhao, G., 2014. Metamorphism and tectonic evolution of the Lhasa terrane, Central Tibet. Gondwana Research 25, 170-189. 
Zhang, Z., Santosh, M. $+2012 f$. Tectonic evolution of Tibet and surrounding regions. Gondwana Research $21,1-3$.

Zhao, Z., Bons, P.B., Wang, G., Liu, Y., Zheng, Y., 2014. Origin and pre-Cenozoic evolution of the south Qiangtang basement, Central Tibet. Tectonophysics 623, 52-66.

Zhou, M.F., Ma, Y., Yan, D.P., Xia, X., Zhao, J.H., Sun, M., 2006b. The Yanbian terrane (Southern Sichuan province, SW China): a Neoproterozoic arc assemblage in the western margin of the Yangtze block. Precambrian Research 144, 19-38.

Zhou, M.F., Yan, D.P., Kennedy, A.K., Li, Y., Ding, J., 2002. SHRIMP U-Pb zircon geochronological and geochemical evidence for Neoproterozoic arc-magmatism along the western margin of the Yangtze block, South China. Earth and Planetary Science Letters 196, 51-67.

Zhou, M.F., Yan, D.P., Wang, C.L., Qi, L., Kennedy, A., 2006a. Subduction-related origin of the 750 Ma Xuelongbao adakitic complex (Sichuan province, China): implications for the tectonic setting of the giant Neoproterozoic magmatic event in South China. Earth and Planetary Science Letters 248, 286-300.

Zhu, D.C., Zhao, Z.D., Niu, Y., Dilek, Y., Hou, Z.Q., Mo, X.X., 2013. The origin and pre-Cenozoic evolution of the Tibetan Plateau. Gondwana Research 23, 1429-1454.

Zhu, D.C., Zhao, Z.D., Niu, Y.L., Mo, X.X., Chung, S.L., Hou, Z.Q., Wang, L.Q., Wu, F.Y., 2011a. The Lhasa Terrane: record of a microcontinent and its histories of drift and growth. Earth and Planetary Science Letters 301, 241-255. 


\section{FIGURE CAPTIONS}

Fig. 1 - (a) Simplified tectonic map of the central-western Tibetan Plateau and Pamir-Karakorum Range (modified after Gaetani et al., 1991 and Robinson, 2009), with location of the Aghil Range (black rectangle). From north to south, the main terranes and sutures of the Tibetan Plateau are TB: Tarim Basin; KL: Kunlun; SG: Songpan-Ganze; NQ: North Qiangtang; SQ: South Qiangtang; LH: Lhasa; I: India; KS: Kunlun Suture; JS: Jinsha Suture; LSSZ: Longmu Tso-Shuanghu Suture Zone; BNSZ: Bangong-Nunjiang Suture Zone; ITSZ: IndusTsangpo Suture Zone, whereas those of the Pamir- Karakorum Range are KM: Karakul-Mazar (North Pamir); CP: Central Pamir; SP: South Pamir; KK: Karakorum; KH/LK: Kohistan-Ladakh; TS: Tanymas Suture; RPSZ: Rushan-Pshart Suture Zone; TBZ: Tirich Boundary Zone; SSZ: Shyok Suture Zone. KKF: Karakorum Fault; KF: Karakax Fault; LCF/ATF: Longmu Co Fault / Althyn Tagh Fault. (b) Geologic map of the Aghil Range, between Kunlun (Yarkand River) and Karakorum (Shaksgam River), modified after Gaetani et al. (1991) and Rolfo et al. (2014), with location of the studied samples (black stars). (c) Sketch of the pre-Mesozoic original relationships between the crystalline basement and the sedimentary cover of the Surukwat Complex. (d) Geologic cross-section from llik to Sughet Jagal (A-B in (b)), with location of the studied samples (white stars).

Fig. 2 - Representative microstructures of the studied samples. Bazar Dara Slates Unit - Sample 06-1: (a) Two-micas + chlorite phyllite: the main foliation $\mathrm{S}_{\mathrm{m}}$, defined by white mica + chlorite + biotite + ilmenite, is locally pervasively crenulated with the appearance of an $\mathrm{S}_{\mathrm{m}+1}$ defined by white mica + ilmenite. Plane Polarized Light (PPL). Surukwat Complex - Sample 06-10: (b) The mylonitic foliation, defined by phengite, wraps around pluri-mm amphibole porphyroclasts (PPL). (c) Detail of an amphibole porphyroclast: the brownish-green amphibole core $\left(\mathrm{Amp}_{1}\right)$ is a relic of the igneous protolith and it is rimmed by a green metamorphic actinolite ( $\mathrm{Amp}_{2}$ ) (PPL). Sample 07-17: (d) The porphyric structure of the dioritic protolith is still preserved (note the $\mathrm{mm}$-sized amphibole porphyroblasts set in a fine-grained matrix of albite + epidote + biotite \pm chlorite) (PPL). (e, f) Details of strongly zoned amphibole crystals, with a dark green core (Amp ${ }_{1}$, magmatic hornblende), a light green rim ( $\mathrm{Amp}_{2}$, metamorphic actinolite) and a discontinuous deep green outermost rim ( $\mathrm{Amp}_{3}$, metamorphic hornblende) (PPL). Sample 06-115: (g) The main foliation $\mathrm{S}_{\mathrm{m}}$, defined by white mica + biotite, wraps around $\mathrm{mm}$-sized garnet porphyroblasts. An earlier $\mathrm{S}_{\mathrm{m}-1}$ is preserved in the microlithons and as an internal foliation within garnet. Chlorite porphyroblasts overgrows the $S_{m}(P P L)$. Plutonic bodies - Sample 06-26: (h) This porphyritic granite is characterized by cm-sized perthitic Kfeldspar; biotite is fresh and plagioclase is slightly zoned (Crossed Polarized Light: XPL). Sample 06-108: (i) In this biotite-bearing granodiorite, $\mathrm{K}$-feldspar is poikilitic and biotite is mostly replaced by chlorite (XPL). 
Fig. 3 - BSE images of monazite $(\mathbf{a}, \mathbf{b})$ and xenotime $(\mathbf{c}, \mathbf{d})$ in sample 06-1 showing location of U/Pb-TE analysis. Scale bar in all images is $50 \mu \mathrm{m}$.

Fig. 4 - BSE images of titanite from samples 06-10 (a) and 06-17 (b-d) showing location of U/Pb analysis.

Fig. 5 - BSE images (a-c) and compositional maps (d) of monazite from sample 06-115 showing location of $\mathrm{U} / \mathrm{Pb}-\mathrm{TE}$ analysis. Monazite grains in (a) are included within garnet and yield Jurassic $\mathrm{U} / \mathrm{Pb}$ ages. Matrix monazite grains $(b-c)$ are Late Cretaceous in age. Matrix monazite that displays core to rim zoning in Th (see 4-2.2 and 6-1.1 in d) gives older $\mathrm{U} / \mathrm{Pb}$ ages interpreted to reflect incomplete recrystallization of Jurassic monazite.

Fig. 6 - Cathodoluminescence (CL) images of zircons from samples 06-108 (a) and 06-26 (b) showing location of $\mathrm{U} / \mathrm{Pb}-\mathrm{TE}$ analysis (large circle) and additional TE analysis (small circle).

Fig. 7 - Tera-Wasserburg plots of $\mathrm{U} / \mathrm{Pb}$ data and plots of chondrite normalized trace element data from zircon in samples 06-26 (a) and 06-108 (b). Black ellipses and black symbols in chondrite normalized plots are used in age interpretation; gray ellipses are not. Ellipses plotted at $1 \sigma$. Age uncertainties reported at 95\% confidence level (MSWD = mean square of weighted deviates). Tera-Wasserburg diagrams were made using Isoplot (Ludwig, 2003). Chondrite normalized plots were calculated using values from McDonough and Sun (1995).

Fig. 8 - Tera-Wasserburg plots of U/Pb data from titanite in samples 06-17 (a) and 06-10 (b). Ellipses are plotted at $1 \sigma$. Lower intercept age uncertainties reported at $95 \%$ confidence level (MSWD $=$ mean square of weighted deviates). Tera-Wasserburg diagrams were made using Isoplot (Ludwig, 2003).

Fig. 9 - Tera-Wasserburg plots of $\mathrm{U} / \mathrm{Pb}$ data and plots of chondrite normalized trace element data from xenotime, sample 06-1 (a) and monazite, sample 06-115 (b). Black ellipses and black symbols in chondrite normalized plots are used in age interpretation; gray ellipses are not. Ellipses plotted at $1 \sigma$. Analysis 5-2.1 is not plotted in (b) due large uncertainty in the ${ }^{207} \mathrm{~Pb} /{ }^{206} \mathrm{~Pb}$ ratio. Age uncertainties reported at $95 \%$ confidence level (MSWD = mean square of weighted deviates). Tera-Wasserburg diagrams were made using Isoplot (Ludwig, 2003). Chondrite normalized plots were calculated using values from McDonough and Sun (1995).

Fig. 10 - Pre-Cenozoic tectonic evolution of Western Tibetan Plateau as inferred from geochronological and petrological data discussed in this paper. The sketch is especially focused on the evolution of the Surukwat 
Complex, whereas it is simplified for the other terranes. Abbreviations for the western Tibet terranes and for the interposed oceans are: KL: Kunlun; BDs: Bazar Dara Slates Unit; SC: Surukwat Complex; LH: Lhasa; I: India; PT: Paleo-Tethys; BN: Bangong-Nunjian Ocean; NT: Neo-Tethys. Abbreviations for suture zones are: KS: Kunlun Suture; JS: Jinsha Suture; BNSZ: Bangong-Nunjian Suture Zone. The black rectangle refers to Fig. 11.

Fig. 11 - Enlargement of Fig. 10 focusing on the Mesozoic evolution of the Surukwat Complex and explaining the development of the accretionary wedge on its southern margin $(\mathbf{a}, \mathbf{c}, \mathbf{e}, \mathbf{g})$. Colour codes are the same as in Fig. 10. The P-T diagrams in $(\mathbf{b}, \mathbf{d}, \mathbf{f}, \mathbf{h})$ show the peak P-T conditions experienced by the Bazar Dara Slates (b) and by the different thrust sheets of the Surukwat Complex (d, f, h) as inferred from the Average PT results (with $1 \sigma$ error ellipses). The P-T path of sample 06-115 is derived from Groppo and Rolfo (2008), whereas that for sample 06-10 is tentatively inferred basing on the Average PT results.

Fig. 12 - (a-h) Simplified paleogeographic sketches showing the relative positions of the Cimmerian Terranes in pre-Cenozoic times, as inferred from the data presented in this paper. The separation between Central Pamir, South Pamir and Karakorum terranes in the Pamir-Karakorum Range is in agreement with one of the possible configurations proposed by Robinson (2015). The tectonic evolution of North Qiangtang and South Qiangtang terranes follows the in situ suture model (e.g. Zhang et al., 2006a,b, 2011); however, the alternative underthurst model interpretation (e.g. Kapp et al., 2000, 2003a; Kapp, 2001) does not significantly influence the paleogeographic reconstruction of western Tibet (see text for further discussion). The dotted grey line in each diagram refers to the location of Fig. 10 for the same time intervals. The black rectangle in (h) locates the study area in the framework of western Tibet, which is enlarged in (i). (i) Proposed correlation between metamorphic and magmatic terranes of western Tibet and those of Central Tibet and Pamir-Karakorum. The Bazar Dara Slates unit (BDS) is correlated to the Karakul Mazar terrane, the Surukwat Complex (SC) and the Aghil Granodiorite (AG) body are correlated to the South Qiangtang terrane, whereas the Shaksgam Sedimentary Belt (SSB) and the Sughet Granodiorite (SG) body are correlated to the South Pamir terrane. Abbreviations for the other terranes, oceans and sutures are as follows: KL: Kunlun; SG: Songpan-Ganze; KM: Karakul-Mazar; NQ: North Qiangtang; SQ: South Qiangtang; A: Amdo; CP: Central Pamir; SP: South Pamir; KK: Karakorum; LH: Lhasa; KH/LK: KohistanLadakh; I: India; KS: Kunlun Suture; JS: Jinsha Suture; TS: Tanymas Suture; LSSZ: Longmu Tso-Shuanghu Suture Zone; RPSZ: Rushan-Pshart Suture Zone; TBZ: Tirich Boundary Zone; BNSZ: Bangong-Nunjiang Suture Zone; SSZ: Shyok Suture Zone; ITSZ: Indus-Tsangpo Suture Zone; KKF: Karakorum Fault; KF: Karakax Fault; LCF/ATF: Longmu Co Fault / Althyn Tagh Fault. 
1

\section{Pre-Cenozoic evolution of the Aghil Range (western Tibetan Plateau): a missing piece of the Tibet-Pamir-Karakorum geopuzzle}

Chiara Groppo ${ }^{a}$, Franco Rolfo ${ }^{a^{*}}$, William C. McClelland ${ }^{b}$, Matthew A. Coble ${ }^{c}$

${ }^{\mathrm{a}}$ Department of Earth Sciences, University of Torino, Torino, Italy and CNR-IGG, Torino

${ }^{b}$ Department of Earth and Environmental Sciences, University of lowa, lowa City, lowa 52242, USA

${ }^{\mathrm{C} D e p a r t m e n t}$ of Geological Sciences, Stanford University, Stanford, California 94305, USA

*Corresponding author:

Franco Rolfo

Department of Earth Sciences, University of Torino,

Via Valperga Caluso 35, 10125 Torino, Italy

e-mail: franco.rolfo@unito.it 


\section{Abstract}

The Tibetan Plateau, largely derived from the accretion of several Gondwana microplates to the southern margin of Asia since the late Palaeozoic, is the highest and largest topographic relief on Earth. Although the first order geodynamic processes responsible for its pre-Cenozoic evolution are quite well-known, many issues are still debated, among which is the timing of collision of each terrane with the southern margin of Asia. Even more uncertain is the pre-Palaeozoic history of these terranes, due to the lack of basement exposures. As a contribution to understanding the pre-Cenozoic evolution of the Tibetan Plateau, this paper focuses on the Aghil Range, a remote and poorly investigated area close to the Karakorum Fault between Kunlun and Karakorum (Xinjiang, China) in western Tibet. The tectono-metamorphic and magmatic evolution of the Aghil Range is investigated using a multidisciplinary approach that combines field mapping, petrology and geochronology (U-Pb on titanite, zircon, monazite and xenotime using SHRIMP-RG). We demonstrate that the Aghil Range preserves a coherent slice of Neoproterozoic crystalline basement with a late Palaeozoic sedimentary cover deposited on a passive continental margin during the Gondwana breakup. This represents the westernmost exposure of Precambrian crystalline basement known so far in the Tibetan Plateau. Furthermore, petrological and geochronological results allow reconstructing the Mesozoic poly-metamorphic evolution of this sector of the Tibetan Plateau, which records the evidence of Middle Jurassic (ca. $170 \mathrm{Ma}$ ) and Late Cretaceous (66 Ma) collisional events, as well as of the Late Jurassic (ca. 150 $\mathrm{Ma}$ ) early subduction of an accretionary complex developed on its southern margin. Evidence of Late Cretaceous subduction-related magmatism preceding the last collisional event is also recorded. These results allow tentative correlation of the different terranes of Central Tibet with those of the PamirKarakorum Range on both sides of the Karakorum fault.

\section{Key-words}

Tibetan Plateau, pre-Cenozoic evolution, Cimmerian orogeny, petrology, U-Pb geochronology

\section{Research highlights}

- The pre-Cenozoic evolution of the Aghil Range (western Tibet) is investigated

- A coherent slice of Neoproterozoic basement with its sedimentary cover is preserved

- A correlation between terranes of Central Tibet and Pamir-Karakorum is proposed 


\section{Introduction}

The Tibetan Plateau, together with the Pamir-Karakorum Range, is the highest and largest topographic plateau on Earth: understanding its formation and evolution is therefore fundamental for clarifying the geodynamic processes leading to crustal thickening and continental growth. The origin, evolution and tectonic architecture of the Tibetan Plateau and of the Pamir-Karakorum Range have been studied for several decades (e.g. Sengör, 1979, 1987; Allégre et al., 1984; Sengör, 1987; Dewey et al., 1988; Gaetani et al., 1990a,b, 1993; Burtman and Molnar, 1993; Matte et al., 1996; Gaetani, 1997; Yin and Harrison, 2000); important advances in understanding their genesis have been made over the last ten years thanks to an increasing number of field, geochemical and geochronological studies as demonstrated by publication of numerous review papers (e.g. Zhang et al., 2012; Zhu et al., 2011, 2013) and special volumes dedicated to this topic (e.g. Zhang and Santosh, 2012; Zanchi et al., 2015; Chung and Niu, 2016; Zhang et al., 2017).

It is now widely accepted that the Tibetan Plateau and Pamir-Karakorum Range derive from the accretion of several Gondwana-derived microplates (also called Cimmerian terranes: Sengör, 1984) to the southern margin of Asia since the late Palaeozoic, in response to the ongoing subduction and progressive closure of the oceanic basins between each terrane (e.g. Allégre et al., 1984; Dewey et al., 1988; Yin and Harrison, 2000; Pan et al., 2012). Moreover, there is increasing evidence that most of the deformation, shortening and crustal thickening within the plateau were the result of these pre-Cenozoic accretionary processes whereas the contribution of India-Asia collision to the building of the plateau was only minor (e.g. Murphy et al., 1997; Yin and Harrison, 2000; Hildebrand et al., 2001; Robinson et al., 2004; Kapp et al., 2003b, 2005, 2007; Guynn et al., 2006; Zhang et al., 2012; Zhu et al., 2013). However, several recent studies explain crustal thickening as related to the underthrusting of Indian lithosphere (e.g. Chen et al., 2017). Although the first order geodynamic processes responsible for the pre-Cenozoic evolution of the plateau are quite well-known, many issues are still debated. These include the timing, duration and direction of oceanic subduction and the timing of collision of each terrane with the southern margin of Asia. Even more uncertain is the Precambrian history of the Cimmerian terranes, due in large part to the scarcity of basement exposures and the predominance of late Palaeozoic or younger supracrustal assemblages (e.g. Pan et al., 2004; Guynn et al., 2012; Zhu et al., 2013 and references therein).

Most studies devoted to understanding the pre-Cenozoic formation and evolution of the Tibetan Plateau and Pamir-Karakorum Range are based on either stratigraphic evidence (e.g. Gaetani et al., 1990b, 1993; Gaetani, 1997; Kapp et al., 2007; Zanchi and Gaetani, 2011; Zanchi et al., 2012; Angiolini et al., 2013, 2015; Gaetani and Leven, 2014; Robinson, 2015; Zeng et al., 2016) or on the distribution, composition and age of subduction- and/or collision- related magmatic rocks (e.g. Schwab et al., 2004; Zhu et al., 2011, 2013; Zhang et al., 2012 and references therein; Zanchetta et al., 2018). Studies of metamorphic rocks are sporadic and limited to few areas, such as the Central Qiangtang Metamorphic Belt (e.g. Kapp et al., 2000, 
2003a; Pullen et al., 2008, 2011; Liang et al., 2012; Zhai et al., 2011b; Zhao et al., 2014), the Amdo terrane (e.g. Guynn et al., 2006, 2012, 2013; Zhang et al., 2012a), the Central Lhasa terrane (e.g. Dong et al., 2011; Zhang et al., 2012b ; Zhang et al., 2014) and the southern Karakorum Terrane (e.g. Searle and Tirrull, 1991; Lemennicier et al., 1996; Fraser et al., 2001; Streule et al., 2009; Searle, 2011).

As a contribution to the understanding of the pre-Cenozoic evolution of the Tibetan Plateau, this study focuses on the metamorphic and magmatic units exposed along the Aghil Range, a remote and poorly investigated area located at the junction between the Tibetan Plateau and the Pamir-Karakorum Range in western Tibet. Interpretation of this area is still controversial, having been alternatively ascribed to the Songpan-Ganze (Tianshuai) terrane (e.g. Valli et al., 2008; Leloup et al., 2012; Pan et al., 2012) or to the Southern (or Western) Qiangtang terrane (e.g. Gaetani et al., 1990a; Robinson, 2009, 2015; Groppo and Rolfo, 2008; Streule et al., 2009; Searle et al., 2010, 2011; Gaetani and Leven, 2014; Rolfo et al., 2014). The aim of this study is therefore twofold: (i) to understand the geological significance of the Aghil Range and assess the nature of the boundaries between the various terranes on both sides of the Karakorum Fault; (ii) to tentatively reconstruct the pre-Cenozoic history of accretion, collision, metamorphism and magmatism of the western portion of the Tibetan Plateau, in comparison with the better known evolution of the central portion of the plateau.

We present field, petrographic, petrologic and geochronologic data on both metamorphic and magmatic rocks exposed along a geological transect, approximately $40 \mathrm{~km}$ long, located between the Kunlun to the north and the Karakorum to the south (Xinjiang, China). The studied metamorphic rocks belong to two different tectonic units (Gaetani et al., 1990a): the "Bazar Dara Slates", a metasedimentary unit located few km south of Mazar (not to be confused with the thick terrigenous Bazardara Series of SE Pamir, which are tentatively correlated with the Singhiè Formation of the Shaksgam Sedimentary Belt by Gaetani and Leven, 2014), and the "Surukwat Complex", a composite sequence of metamorphic thrust sheets derived from both magmatic and sedimentary protoliths. Two granodioritic bodies (i.e. Aghil Granodiorite and Sughet Granodiorite) tectonically interposed between these metamorphic units have been investigated as well.

The petrological and geochronological results allow us to: (i) clarify how the Cimmerian terranes are assembled on both sides of the Karakorum fault (i.e. in the western Tibetan Plateau and in the PamirKarakorum Range); (ii) demonstrate that the Surukwat Complex represents the westernmost exposure of a Precambrian crystalline basement known so far in the Tibetan Plateau; (iii) reconstruct the Mesozoic polymetamorphic evolution of both the Bazar Dara Slates Unit and the Surukwat Complex which record the evidence of Middle Jurassic and Late Cretaceous collisional events, as well as the Late Jurassic early subduction of an accretionary complex developed on the southern margin of the Surukwat Complex; (iv) recognise evidence of Late Cretaceous subduction-related magmatism preceding the collision of the Lhasa and South Qiangtang terranes; and (v) confirm the diachronicity, from east to west, of the Cretaceous 
collisional event between the Lhasa and South Qiangtang terranes in western Tibet and between the Kohistan-Ladakh and Karakorum terranes in Pamir-Karakorum .

\section{Geodynamic Setting of the Tibetan Plateau and Pamir-Karakorum Range}

\subsection{Tibetan Plateau}

The Tibetan Plateau consists of four main E-W trending crustal terranes that rifted from the eastern margin of Gondwana during the late Palaeozoic, drifted northward across the Tethyan Ocean basins and then progressively accreted to the southern margin of Asia during the Mesozoic (e.g. Allégre et al., 1984; Sengör, 1987; Yin and Harrison, 2000). In central Tibet, the following terranes are conventionally distinguished from north to south (Fig. 1a): Kunlun, Songpang-Ganze, Qiangtang and Lhasa terranes. The boundaries between these terranes coincide with different suture zones resulting from the closure of the ocean basins originally interposed between each terrane, and now marked by discontinuous belts of ophiolite fragments and mèlange:

- The Jinsha Suture (JS) separates the Songpan-Ganze terrane from the Qiangtang terrane and records closure of the Paleo-Tethys Ocean; the Songpan-Ganze terrane is commonly interpreted as an extensive arc-accretionary system built along the southern margin of Kunlun during the Triassic (e.g. Matte et al., 1996; Schwab et al., 2004), whose huge volume of sediments did not allow a complete continentcontinent collision between Kunlun and Qiangtang (e.g. Roger et al., 2010).

- The Bangong-Nujiang Suture Zone (BNSZ), more than $1200 \mathrm{~km}$ long, separates the Qiangtang terrane from the Lhasa terrane and resulted from the closure of the Bangong-Nujiang Ocean (or Meso-Tethys Ocean; Sengör, 1984). In western and eastern Tibet, the BNSZ ophiolitic belt is doubled and isolates two micro-blocks interposed between Qiangtang and Lhasa terranes: the Risum block to the west and the Amdo terrane to the east. The Risum block is interpreted as an oceanic arc formed by the intra-oceanic subduction of the Bangong-Nujiang Ocean (Matte et al., 1996; Shi et al., 2004; Shi, 2007; Liu D. et al., 2017). The Amdo terrane is an old micro-continent within the Bangong-Nujiang Ocean that amalgamated with the Qiangtang block before the Lhasa-Qiangtang collision (Xu et al., 1985; Guynn et al., 2006). The Amdo block has been variably correlated to the Lhasa terrane (e.g. Coward et al., 1988; Harris et al., 1988; Yin and Harrison, 2000; Pan et al., 2004) or the Qiangtang terrane (e.g. Guynn et al., 2006, 2012; Zhu et al. 2013).

- The 2000-km-long Indus-Tsangpo Suture Zone (ITSZ) represents the site where the Neo-Tethys lithosphere separating the Lhasa terrane and north India was consumed at a subduction zone dipping northward beneath the Lhasa terrane (Yin and Harrison, 2000). 
- The Longmu Tso-Shuanghu Suture Zone (LSSZ) divides the Qiangtang terrane in two sub-terranes: the North (or Eastern) Qiangtang terrane and the South (or Western) Qiangtang terrane. This suture zone is spatially associated with a high-pressure metamorphic belt (Central Qiangtang Metamorphic Belt, CQMB: Kapp et al., 2000, 2003a), and its origin is still debated. The CQMB has been interpreted either: (i) as a part of the Songpan-Ganze accretionary mèlange that was underthrusted beneath a single Qiangtang terrane during the southward subduction of the Paleo-Tethys along the Jinsha Suture in the early Mesozoic (i.e. underthrust model: e.g. Kapp et al., 2000, 2003a; Kapp, 2001; Pullen et al., 2011), or (ii) as an in situ suture zone formed by northward subduction of a branch of Paleo-Tethys originally separating the South Qiangtang terrane of Gondwanan affinity from the North Qiangtang terrane of Cathaysian affinity (i.e. intra-Qiangtang suture model: e.g. Zhang, 2001; Zhang et al., 2006a,b, 2011; Zhang and Tang, 2009; Liu et al., 2011; Zhai et al., 2011a,b, 2013; Zhu et al., 2013; Zhao et al., 2014).

The timing, duration and direction of oceanic subduction, as well as the timing of final collision between each terrane are still debated. The Paleo-Tethys ocean was subducted northward beneath the Kunlun and Songpan-Ganze terranes by the Late Permian - Early Triassic, as evidenced by the occurrence of a magmatic belt and volcanic arc along the southern margin of Kunlun (e.g. Matte et al., 1996; Xiao et al., 2002, 2003; Liu et al., 2015; Cao et al., 2015); southward subduction in Late Triassic - Early Jurassic times is instead proposed by other studies (e.g. Kapp et al., 2000, 2003a; Zhang et al., 2016). The final collision between the Qiangtang and the Songpan-Ganze/Kunlun terranes occurred in the Late Triassic to Middle Jurassic. The southernmost Bangong-Nunjiang ocean was subducted either northward under the South Qiangtang terrane, or southward beneath the Lhasa Terrane during the Mesozoic (Zhu et al., 2013; Liu D. et al., 2017 and references therein). This was likely an oblique subduction, resulting in a diachronous collision of the Lhasa and Qiangtang terranes from west (Middle Cretaceous) to east (Late Cretaceous) (e.g. Matte et al., 2006; Zhang et al., 2008; Zhu et al., 2013; Liu L. et al. 2017; Liu D. et al., 2017 and references therein).

\subsection{Pamir-Karakorum Range}

The dextral strike-slip Karakorum fault (KKF) (e.g. Phillips et al., 2004; Searle and Phillips, 2007; Phillips, 2008; Valli et al., 2008; Robinson, 2009; Leloup et al., 2011) separates the Tibetan Plateau to the east from the Pamir-Karakorum Range to the west, whose tectonic framework is also the result of the amalgamation of different Gondwana-derived terranes. From north to south these terranes are the Kunlun, Karakul-Mazar (or North Pamir), Central Pamir, South Pamir, Karakoram and Kohistan-Ladakh, and they are bounded by the Kunlun, Tanymas, Rushan-Pshart, Tirich Boundary Zone and Shyok suture zones, respectively (Fig. 1a). The correlation between crustal terranes and suture zones of Pamir-Karakorum and central Tibet is not univocal (e.g. Burtman and Molnar, 1993; Yin and Harrison, 2000; Lacassin et al., 2004; Schwab et al., 2004; Robinson, 2009, 2015; Robinson et al., 2012; Zanchetta et al., 2018). The Karakul-Mazar terrane, bounded 
by the Kunlun suture to the north and the Tanymas Suture to the south, is commonly considered the equivalent of the Songpan-Ganze terrane of central Tibet. Interpretation of the other terranes is less certain. Recent studies suggest that the Central Pamir, South Pamir and Karakoram terranes are correlative to the Qiangtang terrane (e.g. Phillips et al., 2004; Upadhyay et al., 2005; Searle and Phillips, 2007; Robinson et al., 2004; Robinson, 2009, 2015; Searle et al., 2010; Searle, 2011; Angiolini et al., 2013; Yang et al., 2017) and that the Kohistan-Ladakh terrane and the Lhasa terrane of central Tibet are part of a continuous magmatic arc, built on a continental basement in the Lhasa terrane and in the Ladakh region, and on oceanic crust in the Kohistan terrane (e.g. Rolfo et al., 1997; Yin and Harrison, 2000; Robinson et al., 2004; Robinson, 2009, 2015). Following this interpretation, the Shyok Suture, that separates the Karakorum terrane from the Kohistan-Ladakh terrane, would be the equivalent of the Bangong-Nunjiang suture zone. However, other studies suggest that South Pamir is the equivalent of the Lhasa terrane (e.g. Lacassin et al., 2004; Schwab et al., 2004), in which case the Rushan-Pshart Suture Zone would be equivalent to the Bangong-Nunjiang suture zone. An absence of direct correlations between major suture zones east and west of the Karakorum Fault has been also recently proposed (Zanchetta et al., 2018). A better understanding of the western Tibet region and the Aghil Range where the study area is located in particular, is crucial for meaningful correlation of crustal terranes across the Karakorum fault.

\section{Geological Setting}

The Aghil Range in western Tibet (Fig. 1a) was studied along a cross-section between llik (at the confluence between the Yarkand and the Zug Shaksgam rivers) and Sughet Jagal (northern K2 base camp, along the Sarpo Laggo Valley), across the Aghil pass and the Shaksgam Valley (Fig. 1b). Very few geological studies have been performed in this area, tectonically sandwiched between Kunlun to the north and Karakorum to the south. The first "modern", though preliminary, data are reported in Gaetani et al. (1990a, 1991); these results already documented the complexity of the area, characterized by the juxtaposition of different metamorphic, sedimentary or magmatic units. More recently, Groppo and Rolfo (2008) reported the evidence of a possibly old metamorphic basement north of Aghil Pass (i.e. the Surukwat Complex), and constrained the P-T evolution of its structurally upper portion. However, the nature and age of this basement is still unknown, as well as the age of metamorphism. The non-metamorphic Shaksgam Sedimentary Belt was investigated in detail by Gaetani et al. (1990a, 1991) and Gaetani and Leven (2014), whereas the magmatic rocks exposed close to the Aghil Pass (i.e. the Aghil Granodiorite) were studied very recently by Liu L. et al. (2017). Detailed description of the lithological and tectonic architecture along the llik - Sughet Jagal transect and relevant images of field geology and mesoscopic structures are given by Rolfo et al. (2014) and will only be summarized here. 
Starting from llik and going upstream (southward) along the Aghil Dara Valley, the Bazar Dara Slates Unit (Fig. 1b) is a metasedimentary sequence consisting mainly of phyllites and metasandstones that are dipping steeply towards SSE and locally intruded by undeformed Late Triassic granitic bodies (e.g. Mazar from the Surukwat Complex; this is a composite sequence of thrust sheets steeply dipping SSW (Fig. 1b,d) in which, except for a few non-metamorphic slivers, there is a general southward increase in metamorphic grade from lower to higher structural levels (Rolfo et al., 2014). Although pervasively mylonitized, the internal coherence of this basement is mostly preserved (Fig. 1c). From north to south, the Surukwat Complex starts with a non-metamorphic sliver of red sandstone with anhydrite interlayers that shows a strong affinity with the Qiangtang terrane (Leeder et al., 1988), and is petrographically similar to the Jurassic Marpo Sandstone of the Shaksgam Valley (Gaetani et al., 1990a, 1991). A metamorphic basement derived from igneous protoliths is thrust over the red sandstone to the south (Fig. 1d). From lower to higher structural levels it consists of meta-diorite, meta-granodiorite and meta-granite with transposed meta-aplitic dykes. Primary intrusive relationships between the various magmatic protoliths have been obliterated by the pervasive mylonitic deformation which affected this portion of the Surukwat Complex. A small (few-meters-thick) slice of slightly metamorphosed limestone is tectonically intercalated in this metaigneous basement. A few-kilometers-thick layer of metaconglomerate dominated bv granitic and dioritic clasts follows further upstream. Further south, the metaconglomerate is overlain by a km-thick metasedimentary sequence that consists of quartzite, quartzitic gneiss and metapelite with meter-thick intercalations of meta-marl (amphibole-bearing calcschist, biotitic-amphibolitic schist, carbonate-rich garnet-bearing biotitic schist) and impure marble. The medium grade metapelites represent the last unit of the Surukwat Complex, which is bounded to the south by a sharp fault contact with the Aghil intrusive body (Fig. 1b,d). A weakly deformed apophysis of this pluton crops out within the quartzitic gneisses to the north. The Aghil intrusive body mainly consists of amphibole + biotite -bearing granodiorite, with minor monzonite and porphyritic granite, the latter cropping out in the proximity of the Aghil Pass. A Late Cretaceous age has been recently obtained for these magmatic rocks (zircon U-Pb ages; Liu L. et al., 2017).

Another tectonic contact is crossed southward just before the Aghil Pass (Fig. 1b,d) that separates the Aghil Granodiorite from the Shaksgam Sedimentary Belt (Gaetani et al., 1990a, 1991), a 250 km long and 15-20 km wide sedimentary sequence exposed along the Shaksgam Valley and extending to the west of the Karakorum fault for $\sim 150 \mathrm{~km}$ in southeast Pamir (Robinson, 2009). This sedimentary sequence, displaced in a system of open folds, faulted, thrusted and stacked together, is at least $3 \mathrm{~km}$ thick and spans from the Lower Permian to Jurassic (Gaetani et al., 1990a, 1991; Gaetani, 1997; Gaetani and Leven, 2014). The main strand of the Karakorum Fault is crossed a few kilometres south of the junction between the Sarpo Laggo and Shaksgam valleys (Fig. 1b,d). A cataclastic contact separates the Shaksgam Sedimentary Belt (Aghil Dolomite) from the Sughet Granodiorite. This plutonic body, mostly made of biotite-bearing 
granodiorite, crops out in the lower (northern) part of the Sarpo Laggo valley, near Sughet Jagal, and represents the last unit of the investigated geological transect.

This study focuses on six representative samples from the Bazar Dara Slates Unit (BDS: sample 0601), the Surukwat Complex (SC: samples 06-10, 06-17 and 06-115) and the Aghil and Sughet magmatic bodies (samples 06-26 and 06-108). These samples have been selected out of a total of 76 samples (BDS; 16 samples; SC: 54 samples; magmatic bodies: 6 samples) after careful petrographic characterization of the entire sample suite.

\section{Methods}

\subsection{Mineral chemistry}

Minerals were analysed with a Cambridge Stereoscan 360 SEM equipped with an EDS Energy 200 and a Pentafet detector (Oxford Instruments) at the Department of Earth Sciences, University of Torino. The operating conditions were as follows: accelerating voltage was set to $15 \mathrm{kV}$, beam diameter was $2 \mu \mathrm{m}$, and detection limits for oxides were $0.03 \mathrm{wt} \%$. SEM-EDS quantitative data were acquired and processed using the Microanalysis Suite Issue 12, INCA Suite version 4.01; natural mineral standards were used to calibrate the raw data; the $\rho \phi Z$ correction (Pouchou and Pichoir, 1988) was applied. Absolute error is $1 \sigma$ for all calculated oxides. Mineral chemical data of representative minerals are reported in Table 1.

\subsection{Determination of peak P-T conditions in the metamorphic samples}

P-T conditions for all the metamorphic samples were estimated using the "Average PT" routine of THERMOCALC (Holland and Powell, 1998, version 3.33, thermodynamic database 5.5). Activity-composition relationships were calculated using AX. This method, which estimates the optimal P-T conditions using a set of independent reactions that fully describe the thermodynamics of the system, is able to find a result only if the given mineral assemblage defines a sufficient number of reactions between end-members. The obtained results were considered reliable if passed the 'sigfit' test ( $\sigma$ fit < cutoff value), giving P-T uncertainties ( $\sigma \mathrm{T}$ and $\sigma \mathrm{P})$ at $\pm 1 \sigma\left(95 \%\right.$ confidence). End member(s) with erratic behaviour (large $e^{*}$ values) and a low influence on the least squares results (low hat values) were removed from the calculation because they may cause inconsistency in the results (see Powell and Holland, 1994). A pure $\mathrm{H}_{2} \mathrm{O}$ fluid was considered in the calculations. Average P-T results are reported in Table 2.

The pseudosection approach cannot be applied on most of the studied samples. Sample 06-1 (Bazar Dara Slates phyllite) contains significant amounts of calcite, mostly concentrated in late veins, and it is not 
possible to obtain the equilibrium bulk composition needed for the pseudosection calculation. Similarly, an equilibrium bulk composition cannot be determined for samples 06-10 and 06-17 (meta-granodiorite and meta-diorite from the Surukwat Complex), which are clearly not completely re-equilibrated, as suggested by the presence of relict magmatic hornblende crystals (see section 4.1.2). Therefore, the pseudosection approach has been applied only on sample 06-115 (two-micas, garnet-bearing micaschist from the Surukwat Complex). The pseudosection for this sample was already calculated by Groppo and Rolfo (2008) and it was used to constrain its complete P-T evolution.

\subsection{Geochronology and Trace Element Analyses}

$\mathrm{U} / \mathrm{Pb}$ geochronology was performed on zircon separated from igneous samples $(06-26,06-108)$ and titanite, monazite, and xenotime in-situ on polished thin sections of metamorphic rocks (06-1, 06-10, 06-17, 06-115), using the SHRIMP-RG (sensitive high-resolution ion microprobe with reverse geometry) instrument at the Stanford-U.S. Geological Survey Micro-Analysis Center at Stanford University.

Heavy mineral separates from granitoid samples $06-26$ and 06-108 were obtained by standard pulverizing, magnetic and heavy liquid methods. Individual zircon grains were handpicked under alcohol, mounted in epoxy resin with natural zircon standards and polished to expose the grain centers for analysis by secondary ion microprobe spectrometry (SIMS). Zircon grains were imaged by cathodoluminescence (CL) to expose intra-grain zoning or complexity and aid in placing SIMS spots. The U-Pb and trace element analysis (Tables 3 and SM1a) was performed simultaneously following routines outlined in Barth and Wooden $(2006,2010)$. Instrument mass fractionation corrections were calibrated by replicate analysis of the zircon standard R33 zircon (419 Ma; Black et al., 2004) with a $2 \sigma$ calibration error for the $\mathrm{R} 33{ }^{206} \mathrm{~Pb} /{ }^{238} \mathrm{U}$ ratio of $0.69 \%$ for the analytical session added in quadrature. Ages were calculated from ${ }^{206} \mathrm{~Pb} /{ }^{238} \mathrm{U}$ ratios corrected for common $\mathrm{Pb}$ using the ${ }^{207} \mathrm{~Pb}$ method using measured ${ }^{207} \mathrm{~Pb} /{ }^{206} \mathrm{~Pb}$ ratios or using the ${ }^{204} \mathrm{~Pb}$ method (see Williams, 1998). The U concentration was calibrated with Madagascar Green (MAD-559; 3940 ppm U,Coble et al., 2018). Data reduction and plotting utilized programs Squid 2.51 and Isoplot 3.76 of Ludwig $(2009,2012)$.

The acquisition routine included ${ }^{89} \mathrm{Y},{ }^{139} \mathrm{La},{ }^{140} \mathrm{Ce},{ }^{146} \mathrm{Nd},{ }^{147} \mathrm{Sm},{ }^{153} \mathrm{Eu},{ }^{155} \mathrm{Gd},{ }^{163} \mathrm{Dy}^{16} \mathrm{O},{ }^{166} \mathrm{Er}^{16} \mathrm{O}$, ${ }^{172} \mathrm{Yb}^{16} \mathrm{O},{ }^{90} \mathrm{Zr}_{2}{ }^{16} \mathrm{O}$, and ${ }^{180} \mathrm{Hf}^{16} \mathrm{O}$ simultaneous with $\mathrm{U} / \mathrm{Pb}$ analysis. In a separate analytical session, additional trace element analyses were performed, including ${ }^{27} \mathrm{Al},{ }^{30} \mathrm{Si},{ }^{31} \mathrm{P},{ }^{39} \mathrm{~K},{ }^{40} \mathrm{Ca},{ }^{28} \mathrm{Si}^{16} \mathrm{O},{ }^{45} \mathrm{Sc},{ }^{48} \mathrm{Ti},{ }^{49} \mathrm{Ti},{ }^{56} \mathrm{Fe},{ }^{89} \mathrm{Y}$, ${ }^{93} \mathrm{Nb},{ }^{94} \mathrm{Zr}^{1} \mathrm{H}$, and ${ }^{96} \mathrm{Zr}$. Each isotope was normalized to ${ }^{28} \mathrm{Si}^{16} \mathrm{O}$ or ${ }^{90} \mathrm{Zr}_{2}{ }^{16} \mathrm{O}$, and concentrations were calibrated against zircon standard MAD-559 (Coble et al., 2018). The estimated errors based on repeated analysis of MAD-559 was 6 to $10 \%$ for $\mathrm{P}, \mathrm{Sc}, \mathrm{Ti}, \mathrm{Y}$ and $\mathrm{Nb}$. The uncertainty of $\mathrm{Al}, \mathrm{K}, \mathrm{Ca}$, and Fe were higher (up to $45 \%$ RSD), but these elements were measured only to evaluate if the analytical spot intersected an inclusion or alteration. For example, grain 0608-2.1, Sc, Nb, and Ti were omitted because $\mathrm{Al}, \mathrm{K}$ and Fe were 
$\sim 20$ to $100 x$ higher than other zircon from the same sample. Chondrite normalized plots were calculated using values from McDonough and Sun (1995). The ${ }^{49} \mathrm{Ti}$ data were used to determine the Ti content to avoid interference of ${ }^{96} \mathrm{Zr}^{2+}$ with the ${ }^{48} \mathrm{Ti}$ peak (Watson and Harrison, 2005). Ti-in-zircon temperatures were calculated using Ferry and Watson (2007), assuming the activity of $\mathrm{SiO}_{2}$ is equal to one $\left(a_{\mathrm{SiO} 2}=1\right)$ and activity of $\mathrm{TiO}_{2}$ is approximately $0.7\left(a_{\mathrm{TiO} 2}=0.7\right)$ for rutile-absent siliceous melts (Hayden and Watson, 2007).

Titanite (samples 06-10 and 06-17), monazite (06-115, 06-1), and xenotime (06-115, 06-1) were analyzed in-situ in polished thin sections that were cut into fragments and mounted with appropriate natural standards in large format epoxy mounts (megamounts). Elemental maps showing $\mathrm{U}, \mathrm{Y}, \mathrm{Ce}, \mathrm{P}, \mathrm{Ca}$, and Th concentrations of monazite and high contrast backscatter electron (BSE) images of titanite, monazite and xenotime were generated to identify zoning prior to analysis. Monazite element maps were collected on a JEOL JXA-0823 Electron Microprobe at the University of lowa and BSE imaging was performed at Stanford University using a JEOL 5600 SEM.

$\mathrm{U}-\mathrm{Pb}$ analysis of titanite (Tables 4 and SM1b) monazite (Tables 5 and SM1c), and xenotime (Tables 6 and SM1d) followed the same analytical routine used for zircon, except ${ }^{89} Y$ was not included in the acquisition table for xenotime and only $\mathrm{U}$ and Th were measured as trace elements for titanite. $\mathrm{U}-\mathrm{Pb}$ ages were standardized relative to 44069 monazite (425 Ma; Aleinikoff et al., 2006), MG-1 xenotime (490 Ma; Fletcher et al., 2010; Aleinikoff et al., 2012), and MMs titanite (524 Ma; Schoene and Bowring, 2006) reference materials for monazite, xenotime, and titanite unknown samples, respectively. For trace elements, each isotope was normalized ${ }^{140} \mathrm{Ce}^{31} \mathrm{P}^{16} \mathrm{O}_{2},{ }^{89} \mathrm{Y}^{16} \mathrm{O}_{2}$, or ${ }^{40} \mathrm{Ca}^{48} \mathrm{Ca}^{48} \mathrm{Ti}^{16} \mathrm{O}_{2}$, and trace element concentrations were standardized relative to 44069 monazite (calibrated relative to Namibia (NAM) monazite; Aleinikoff et al., 2012), MG-1 xenotime, or BLR titanite (Aleinikoff et al., 2007) for monazite, xenotime, and titanite, respectively.

Common $\mathrm{Pb}$ composition for titanite samples was determined by linear regression of all analyses on a 3D Tera-Wasserburg plot which yielded a data-defined ${ }^{207} \mathrm{~Pb} /{ }^{206} \mathrm{~Pb}$ upper intercept of 0.9096 , interpreted as the best estimate of the common $\mathrm{Pb}$ composition. All other mineral use initial common $\mathrm{Pb}$ isotopic composition approximated from Stacey and Kramers (1975). Data reduction for geochronology follows the methods described by Williams (1998) and Ireland and Williams (2003), using the MS Excel add-in programs Squid2.51 and Isoplot3.76 of Ken Ludwig $(2009,2012)$. For titanite, the ${ }^{206} \mathrm{Ub} /{ }^{238} \mathrm{U}$ calibration constant utilized a data-defined slope of 1.24 through the distribution of $\mathrm{MMs}$ analyses on a plot of $\ln \left(\mathrm{UO}^{+} / \mathrm{U}^{+}\right)$vs $\ln \left(\mathrm{Pb}^{+} / \mathrm{U}^{+}\right)$. Zircon was calculated with a fixed slope of 2.0. Monazite and xenotime analysis used energy filtering to eliminate the isobaric interference at mass ${ }^{204} \mathrm{~Pb}$, and a calibration of $\ln \left(\mathrm{UO}_{2}{ }^{+} / \mathrm{UO}^{+}\right)$vs $\ln \left(\mathrm{Pb}^{+} / \mathrm{UO}^{+}\right)$with a data-defined slope $(0.60$ and 2.14 , respectively), following methods modified from Fletcher et al. (2010) and Cross and Williams (2018). 


\section{Results}

\subsection{Petrography and petrology of the studied samples}

\subsubsection{Bazar Dara Slates Unit (sample 06-1)}

The Bazar Dara Slates Unit exposed along the lower Aghil Dara Valley consists of a metasedimentary sequence of sandstones, siltstones and slates, steeply dipping towards SSE and locally rich in deformed quartz + carbonate veins. Sample 06-1, collected ca. 4 km south-east of Ilik (N36²2'28.4" E7640'54.4" $3560 \mathrm{~m}$ ), is a two-micas + chlorite phyllite (meta-sandstone) consisting of quartz, muscovite, biotite, chlorite, calcite, minor albite and accessory ilmenite (Fig. 2a). Most calcite is a late phase, concentrated in millimetric veins either concordant or discordant with respect to the main foliation; however, it cannot be excluded that minor calcite is also present in the equilibrium assemblage. The main foliation $\left(S_{m}\right)$, defined by the preferred orientation of muscovite ( $\mathrm{Si}=3.13-3.25$ a.p.f.u. on the basis of 11 oxygens), chlorite $\left(\mathrm{X}_{\mathrm{Mg}}=\right.$ 0.53-0.54), biotite ( $\mathrm{X}_{\mathrm{Mg}}=0.51-0.54 ; \mathrm{Ti}=0.11-0.12$ a.p.f.u.) and ilmenite, is pervasively crenulated, with the local appearance of an $S_{m+1}$ defined by white mica and ilmenite. Minor monazite and xenotime occur as anhedral grains with no clear relationship relative to the dominant foliation (Fig. 3).

Equilibrium P-T conditions for this sample were calculated for the $\mathrm{S}_{\mathrm{m}}$ assemblage $\mathrm{Qz}+\mathrm{Ab}+\mathrm{Chl}+$ $\mathrm{Mu}+\mathrm{Bt}+\| \mathrm{m}$, which resulted in $320 \pm 32{ }^{\circ} \mathrm{C}, 5.2 \pm 0.9 \mathrm{kbar}$ (i.e. greenschist-facies conditions) (Table 2). The rare occurrence of relict phengite flakes ( $\mathrm{Si}=3.32-3.39$ a.p.f.u.) partially replaced by muscovite suggests a complex metamorphic evolution, possibly characterized by an earlier high-pressure stage $\left(p r e-S_{m}: Q z+A b+\right.$ Chl + Phe) .

\subsubsection{Surukwat Complex (samples 06-10, 06-17, 06-115)}

\subsubsection{Meta-diorite and meta-granodiorite (samples 06-10 and 06-17)}

The lowermost portion of the Surukwat Complex consists of a sequence of strongly mylonitized metabasites of dioritic to granodioritic composition with sub-vertical attitude, alternating with granitic to aplitic layers (Fig. 1d). Sample 06-10 and 06-17 are representative examples of the most and less deformed lithologies, respectively.

Sample 06-10 (N36 $17^{\prime} 54,8^{\prime \prime} \mathrm{E}^{\circ} 6^{\circ} 5^{\prime} 22,8^{\prime \prime}$ - $3830 \mathrm{~m}$ ) is a mylonitized hornblende-bearing metagranodiorite still preserving mineralogical relics of the igneous protolith (Fig. 2 b). It is characterized by mmsized, sharply zoned amphibole porphyroclasts (Fig. 2 b,c), with a yellow-pale green relic core (i.e. Amp : $^{\circ}$ magmatic Mg-hornblende to edenite; $\mathrm{Si}=6.6-7.1$ a.p.f.u., $\mathrm{Al}^{\mathrm{IV}}=1.1-1.4$ a.p.f.u., $\mathrm{Al}^{\mathrm{VI}}=0.2-0.5$ a.p.f.u., $\mathrm{X}_{\mathrm{Mg}}=$ 0.55-0.70) surrounded by a light green rim (Amp $\mathrm{Am}_{2}$ metamorphic actinolite; $\mathrm{Si}=7.5-7.8, \mathrm{Al}^{\mathrm{IV}}=0.2-0.6$ a.p.f.u., $\mathrm{Al}^{\mathrm{Vl}}=0.0-0.15$ a.p.f.u., $\left.\mathrm{X}_{\mathrm{Mg}}=0.65-0.80\right)$. $\mathrm{A}$ very thin outermost rim of $\mathrm{Mg}$-hornblende $\left(\mathrm{Amp}_{3}\right.$ : $\mathrm{Si}=$ 7.2-7.4 a.p.f.u., $\mathrm{Al}^{\mathrm{IV}}=0.6-0.8$ a.p.f.u., $\mathrm{Al}^{\mathrm{VI}}=0.15-0.32$ a.p.f.u., $\mathrm{X}_{\mathrm{Mg}}=0.65-0.72$ ) is locally observed. Amphibole 
porphyroclasts are wrapped around by the pervasive mylonitic foliation (Fig. 2b,c), mainly defined by phengitic white mica ( $\mathrm{Si}=3.30-3.37$ a.p.f.u.) locally rimmed by muscovite ( $\mathrm{Si}=3.20-3.30$ a.p.f.u.), associated with chlorite $\left(\mathrm{X}_{\mathrm{Mg}}=0.65-0.67\right)$, quartz, albite $\left(\mathrm{Ab}_{96-100}\right)$ and epidote $\left(\mathrm{Ps}_{20-26}\right)$. Titanite, allanite and minor rutile occur as accessory minerals. Titanite is present both as large (100-200 $\mu \mathrm{m}$ in size) subhedral grains with common opaque intergrowths, interpreted as relics of the magmatic protolith, and as small $(<$ $10 \mu \mathrm{m}$ ) euhedral grains aligned in the main foliation, interpreted as metamorphic (Fig. 4a). Due to the very small size of the metamorphic titanite, only the larger magmatic grains have been dated.

Sample 06-17 (N36² $17^{\prime} 33.0^{\prime \prime} \mathrm{E} 76^{\circ} 34^{\prime} 58.2^{\prime \prime}-3870 \mathrm{~m}$ ) is a poorly deformed, hornblende + biotitebearing meta-diorite, still preserving the porphyric structure of the protolith (Fig. $2 \mathrm{~d}$ ). The deep-green, $\mathrm{mm}$ sized, magmatic hornblende $\left(\mathrm{Amp}_{1}\right.$ : magmatic Fe-hornblende; $\mathrm{Si}=6.5-7.3$ a.p.f.u., $\mathrm{Al}^{\mathrm{IV}}=$ 0.7-1.5 a.p.f.u., $\mathrm{Al}^{\mathrm{vI}}$ $=0.3-0.6$ a.p.f.u., $\left.\mathrm{X}_{\mathrm{Mg}}=0.34-0.50\right)$ is surrounded by a light green actinolitic rim ( $\mathrm{Amp}_{2}$ : metamorphic actinolite; $\mathrm{Si}=7.5-7.8, \mathrm{Al}^{\mathrm{IV}}=0.2-0.4$ a.p.f.u., $\mathrm{Al}^{\mathrm{VI}}=0.1-0.3$ a.p.f.u., $\mathrm{X}_{\mathrm{Mg}}=0.54-0.56$ ), in turn overgrown by a thin outermost rim of deep-green Fe-hornblende $\left(\mathrm{Amp}_{3}\right.$ : metamorphic Fe-hornblende; $\mathrm{Si}=$ 6.8-7.1 a.p.f.u., $A I^{\mathrm{IV}}=0.9-1.2$ a.p.f.u., $A \mathrm{I}^{\mathrm{VI}}=0.4-0.6$ a.p.f.u., $\mathrm{X}_{\mathrm{Mg}}=0.38-0.45$ ) (Fig. 2e,f). The former plagioclase phenocrysts of the protolith are replaced by $\mathrm{mm}$-sized, slightly zoned albite porphyroblasts (core: $A b_{97-100} ;$ rim: $A b_{95-97} \pm$ epidote $\left(\mathrm{Ps}_{25-30}\right)$, whereas magmatic biotite is replaced by fine-grained aggregates of greenish-brown biotite $\left(X_{\mathrm{Mg}}=0.40-0.42 ; \mathrm{Ti}=0.12-0.13\right.$ a.p.f.u. $)+$ epidote $\left(\mathrm{Ps}_{15-20}\right)+$ minor chlorite $\left(\mathrm{X}_{\mathrm{Mg}}=0.45-0.47\right)$ (Fig. 2f). Amphibole and albite porphyroblasts are set in a fine-grained matrix consisting of epidote + albite + minor quartz. Titanite occurs as large (up to $1 \mathrm{~mm}$ ) aggregates of fine-grained euhedral crystals (Fig. 4b-d), interpreted as relics of the magmatic protolith.

The observed mineral assemblages and compositions suggest that both samples 06-10 and 06-17 preserve the evidence of two distinct metamorphic events. The first event was more pervasive and was responsible for the growth of the actinolitic rim at the expenses of the magmatic hornblende in both samples, in equilibrium with albite + epidote + chlorite, \pm phengite (sample 06-10), \pm biotite (sample 06-17); the second event is marked by the appearance of the hornblende outermost rim in equilibrium with albite + epidote, \pm muscovite and chlorite in sample 06-10, and \pm biotite in sample 06-17. Equilibrium P-T conditions of the first metamorphic event were calculated for the assemblages Act $+\mathrm{Ab}+\mathrm{Phe}+\mathrm{Chl}+\mathrm{Ep}+$ $\mathrm{Qtz}+\mathrm{Rt}+$ Ttn of sample $06-10$, which resulted to be $482 \pm 20{ }^{\circ} \mathrm{C}, 11.5 \pm 1.2 \mathrm{kbar}$ (i.e. transition between greenschist- and blueschist-facies conditions; Fig. SM1); the second metamorphic event was constrained at $512 \pm 30^{\circ} \mathrm{C}, 4.5 \pm 1.7 \mathrm{kbar}$ (i.e. transition between greenschist- and amphibolite-facies conditions; Fig. SM1) using the $\mathrm{Hbl}+\mathrm{Ab}+\mathrm{Mu}+\mathrm{Chl}+\mathrm{Ep}+\mathrm{Qtz}+\mathrm{Rt}+$ Ttn assemblage of sample 06-10 (Table 2). Mineral assemblages of sample 06-17 do not define enough reactions for Average PT to work, but are nevertheless consistent with the results obtained from sample 06-10. Overall, these data suggest a clockwise P-T evolution characterized by relatively high-P peak conditions of $\sim 480^{\circ} \mathrm{C}, 11$ kbar followed by decompression coupled with moderate heating at $\sim 510^{\circ} \mathrm{C}, 4.5 \mathrm{kbar}$. 
5.1.2.2 Two-micas, garnet-bearing, metapelite (sample 06-115)

At its uppermost structural level, the Surukwat Complex mostly consists of metapelitic lithologies with minor intercalations of biotite-rich amphibolites and impure marbles likely derived from marl and limestone protoliths, respectively (Fig. 1d). Two of these metapelites, among which sample 06-115 studied in this work, have been petrologically investigated by Groppo and Rolfo (2008). Sample 06-115 is a twomicas, garnet-bearing micaschist consisting of quartz, muscovite, biotite, garnet, plagioclase $\left(\mathrm{An}_{5-18}\right)$, chlorite and accessory ilmenite (Fig. $2 \mathrm{~g}$ ). The main schistosity $\left(\mathrm{S}_{\mathrm{m}}\right)$ is defined by the alignment of muscovite ( $\mathrm{Si}=3.00-3.10$ a.p.f.u.), biotite $\left(\mathrm{X}_{\mathrm{Mg}}=0.42-0.50 ; \mathrm{Ti}=0.09-0.11\right.$ a.p.f.u. $)$ and ilmenite, and derives from the transposition of an earlier foliation $\left(\mathrm{S}_{\mathrm{m}-1}\right)$ defined by the same phases and still preserved in the microlithons (Fig. 2g). Garnet porphyroblasts (Alm ${ }_{71-75} \mathrm{Sps}_{12-15} \operatorname{Prp}_{7-9} \mathrm{Grs}_{2-3}$ ) are enveloped by the $S_{m}$ and overgrow the $S_{m-1}$, still preserved as an internal foliation (Fig. $2 \mathrm{~g}$ ). The outermost garnet rim is characterized by a sharp increase in $X_{M n}\left(A_{1 m} m_{69-71} \mathrm{Sps}_{20-21} \operatorname{Prp}_{6-7} \mathrm{Grs}_{2-3}\right)$, likely reflecting diffusional re-equilibration at the onset of the $S_{m}$ development. Late chlorite flakes $\left(X_{M g}=0.45-0.47\right)$ statically overgrow the $S_{m}$.

Monazite and rare xenotime are present as accessory minerals. Monazite occurs as subhedral grains within garnet and as elongate grains and clusters of grains aligned parallel to the dominant foliation in the matrix (Fig. 5).

The results of thermodynamic modeling (pseudosection approach: Groppo and Rolfo, 2008) suggest that the peak assemblage $(\mathrm{Grt}+\mathrm{Wm}+\mathrm{Bt}+\mathrm{PI}+\mathrm{Qz}+\mathrm{Ilm})$ grew at $580-600{ }^{\circ} \mathrm{C}, 8-9 \mathrm{kbar}$; consistent results are given by the Average PT method applied on the same assemblage $\left(645 \pm 26^{\circ} \mathrm{C}, 8.2 \pm 1.2 \mathrm{kbar}\right.$ ) (Table 2; Fig. SM1). Basing on the pseudosection results, Groppo and Rolfo, 2008 further constrained the main foliation development at ca. $500{ }^{\circ} \mathrm{C}, 5 \mathrm{kbar}$. Furthermore, combining the results obtained from sample 06-115 with those obtained from a second metapelite sample (06-117), the same authors inferred a steep and narrow anticlockwise P-T evolution for this portion of the Surukwat Complex (Fig. SM1).

\subsubsection{Aghil and Sughet magmatic bodies (samples 06-26, 06-108)}

Sample 06-26 (N36²11'02.4" E76³7'32.7" - $4905 \mathrm{~m}$ ) was collected from the Aghil Granodiorite body, in the proximity of the Aghil Pass. It is a biotite-bearing porphyritic granite crosscutting the main granodiorite, with perthitic K-feldspar crystals up to several centimeters in length (Fig. 2h). Plagioclase is zoned, with the Ca-richer core locally altered in sericite \pm saussurite, and a thin albite rim. Biotite is partially replaced by chlorite. Zircon and apatite are abundant among the accessory minerals and are often included in biotite. Sample 06-108 (N3604'08.3" E76²4'52.4'" - 3887 m) was collected from the Sughet Granodiorite body, near Sughet Jagal. It is a biotite-bearing granodiorite with poikilitic K-feldspar, zoned plagioclase partially altered in sericite, and brown biotite pervasively replaced by chlorite (Fig. 2i); apatite, zircon, and allanite occur as accessory minerals. 


\subsection{Geochronology results}

\subsubsection{Zircon}

Zircon from the Aghil (06-26) and Sughet (06-108) granodiorite bodies is euhedral with well-developed oscillatory zoning (Fig. 6). Sample 06-26 yielded reproducible ages and consistent REE patterns (Fig. 7a). Eight analyses define a weighted mean ${ }^{206} \mathrm{~Pb} /{ }^{238} \mathrm{U}$ age of $83 \pm 1 \mathrm{Ma}$ (MSWD=1.6) (Fig. 7a and Table 3). Results from sample 06-108 exhibit more scatter with one Proterozoic and 11 Cretaceous apparent ages. The Proterozoic age is interpreted as a xenocrystic core. Seven of the younger ages define a weighted mean ${ }^{206} \mathrm{~Pb} /{ }^{238} \mathrm{U}$ age of $102 \pm 1 \mathrm{Ma}$ (MSWD=0.9; Fig. 7b, Table 3). Two slightly older analyses are interpreted to reflect mixture of xenocrystic cores and younger magmatic zircon. The two younger analyses are inferred to record younger disturbance possibly associated with emplacement of the latest magmatic products of the Sughet granodiorite suite.

\subsubsection{Titanite}

Titanite ${ }^{206} \mathrm{~Pb} /{ }^{238} \mathrm{U}$ analyses from samples 06-10 and 06-17 (Surukwat Complex) generally contain low $\mathrm{U}$ (average $2 \mathrm{ppm} \mathrm{U}$ ) and high common $\mathrm{Pb}$ resulting in mixing array on Tera-Wasserburg plots (Fig. 8). Regression of analyses from sample 06-17 yields a well-defined 3-D isochron intercept age of $796 \pm 29 \mathrm{Ma}$ (MSWD=1.7), that is consistent with a weighted mean ${ }^{206} \mathrm{~Pb} /{ }^{238} \mathrm{U}$ age of $772 \pm 31 \mathrm{Ma}(\mathrm{MSWD}=2.4$ ) for the same data. All analyses from sample 06-10 (large titanite grains) are dominated by common $\mathrm{Pb}$, plotting near the upper intercept, with a regression that defines a lower intercept of $635 \pm 410 \mathrm{Ma}$, consistent with results of sample 06-17. Titanite ages from both samples are interpreted to record the protolith age of the orthogneiss bodies.

\subsubsection{Xenotime and monazite}

Xenotime analyses from sample 06-1 (Bazar Dara Slates Unit) define a weighted mean age of $174 \pm 11 \mathrm{Ma}$ $(M S W D=2.8)($ Fig. 9a, Table 6) and show a middle REE (MREE) enriched patterns (Fig. 9a) with strong depletion in light REE (LREE) characteristic of metamorphic xenotime (e.g. Aleinikoff et al., 2015). The xenotime grains occur in the matrix and have an ambiguous relationship with the dominant foliation. The xenotime ages are interpreted to record metamorphism at ca. $170 \mathrm{Ma}$. Two matrix monazite grains in sample 06-1 yield ${ }^{206} \mathrm{~Pb} /{ }^{238} \mathrm{U}$ ages of $153 \pm 3 \mathrm{Ma}$ and $161 \pm 4 \mathrm{Ma}$, which we interpret to be consistent with the ca. 170 Ma metamorphic age derived from xenotime, whereas a much younger metamorphic age of 35 $\pm 17 \mathrm{Ma}$ is recorded by a single matrix monazite.

In sample 06-115 (Surukwat Complex), xenotime is very rare. One grain of xenotime gave a ${ }^{204} \mathrm{~Pb}$ corrected ${ }^{206} \mathrm{~Pb} /{ }^{238} \mathrm{U}$ age of $165 \pm 6 \mathrm{Ma}$, which is consistent with the ca. $170 \mathrm{Ma}$ metamorphic age derived 
from xenotime in sample 06-1. Monazite in sample 06-115 dominantly occurs in the matrix but is locally preserved within garnet (Fig. 5). The monazite shows negative Eu anomalies and heavy REE depletion (Fig. 9b) consistent with growth in the presence of feldspar and garnet, respectively (e.g. Rubatto et al., 2013). Two monazite ${ }^{206} \mathrm{~Pb} /{ }^{238} \mathrm{U}$ age populations occur in this sample: (i) two monazite grains included in garnet gave ${ }^{206} \mathrm{~Pb} /{ }^{238} \mathrm{U}$ ages of $144 \pm 4 \mathrm{Ma}$ and $157 \pm 6 \mathrm{Ma}$ (Fig. 9b), thus defining a ca. $150 \mathrm{Ma}$ monazite generation; (ii) nine analyses from matrix monazite in sample 06-115 (Fig. 9b, Table 5) define a weighted mean age of $66 \pm 2$ Ma (MSWD = 1.1) (second monazite generation). The remaining grains record ages between 108 and $70 \mathrm{Ma}$ that are interpreted to reflect partial resetting of the older monazite formed originally at ca. $150 \mathrm{Ma}$. This interpretation is supported by core to rim Th zoning observed in grains that give $\mathrm{U} / \mathrm{Pb}$ ages $>70 \mathrm{Ma}$ (Fig. 5).

\section{Discussion}

\subsection{Pre-Cenozoic geodynamic evolution of the Aghil Range}

\subsubsection{The Surukwat Complex: a relic of Neoproterozoic basement with a possible late Palaeozoic cover} The U-Pb titanite ages obtained for the meta-granodiorite and meta-diorite (samples 06-10 and 06-17) from the Surukwat Complex tightly constrain the formation of the igneous protoliths at $796 \pm 29 \mathrm{Ma}$, i.e. during the Neoproterozoic.

Although not common, fragments of Neoproterozoic crystalline basement have been reported from different terranes in the central Tibetan Plateau (see Zhu et al., 2013 for a review). In the central Lhasa and Amdo terranes, U-Pb dating of zircons in gneissic rocks yielded 787-748 Ma (Nam Tso area: Hu et al., 2005) and 920-820 Ma (Amdo: Guynn et al., 2006, 2012) ages, respectively. Pre-Cambrian basement exposures are not reported so far from the Qiangtang terrane, the oldest basement rocks having been dated as Ordovician (Pullen et al., 2011; Zhao et al., 2014) or Cambro-Ordovician (Kapp et al., 2000). However, the existence of $\mathrm{a}>740 \mathrm{Ma}$ old basement in the Qiangtang terrane is suggested by Neoproterozoic inherited zircon ages obtained from an Early-Cretaceous granite from the Longmu Co area, western Tibet (Leloup et al., 2012). Neoproterozoic ages (ca. 865-825 Ma) have been also obtained for fragments of crystalline basement exposed in the southern part of the Songpan-Ganze terrane, in eastern Tibet (Roger and Calassou, 1997; Zhou et al., 2002, 2006a,b). Relicts of a possibly pre-Cambrian basement are also reported from the Karakorum (e.g. Le Fort et al., 1994; Zanchi and Gaetani, 2011), South Pamir (East Hindu Kush) (e.g. Zanchi and Gaetani, 2011) and Central Pamir (e.g. Schwab et al., 2004) terranes of the PamirKarakorum Range. All these data suggest that the different Gondwana-derived terranes which constitute the Tibetan Plateau and the Pamir-Karakorum Range are characterized by similar pre-Cambrian igneous basements, likely formed during the initial stages of Rodinia break-up (e.g. Guynn et al., 2012 and 
references therein). Our data allow the recognition of a new exposure of such Pre-Cambrian basement in the Surukwat Complex: this finding represents the westernmost occurrence, known so far, of Pre-Cambrian basement rocks in the Tibetan Plateau.

The Neoproterozoic basement of the Surukwat Complex is overlaid by a meta-sedimentary cover whose protoliths (i.e. conglomerate immediately overlying the igneous basement followed upward by sandstone and then mudstone with marl and limestone intercalations) are compatible with deposition in a passive continental margin setting (Fig. 1c). The age of these sedimentary protoliths is unknown, but it should be not younger than Triassic, because our data demonstrate that during Middle Jurassic these sediments were already metamorphosed (see below, Section 6.1.2). Basing on the strong similarities with late Palaeozoic meta-sedimentary sequences overlying the crystalline basement in the central Lhasa, Amdo and Qiangtang terranes (Kapp et al., 2000, 2003b, 2007; Leier et al., 2007; Pullen et al., 2008; Guynn et al., 2012), we suggest that the protoliths of the meta-sedimentary sequence exposed in the upper portion of the Surukwat Complex might be late Palaeozoic in age. In the absence of geochronological data constraining the age of the sedimentary protoliths, however, this hypothesis remains speculative, but is nevertheless consistent with the observed lithological associations. Our results thus suggest that the Surukwat Complex is a coherent slice of Neoproterozoic crystalline basement of dioritic to granodioritic and granitic composition, with a possibly late Palaeozoic sedimentary cover (Fig. 1c) deposited on a passive continental margin during the Gondwana break-up.

\subsubsection{The Middle Jurassic collision between the Bazar Dara Slates and the Surukwat Complex and the} Cimmerian Orogeny

The first tectono-metamorphic event experienced by the studied units is Middle Jurassic (ca. $170 \mathrm{Ma}$ ). This event is registered by xenotime and monazite in the two micas phyllite of the Bazar Dara Slates Unit (sample 06-1), and by rare xenotime grains in the garnet-bearing micaschist from the Surukwat Complex Unit (sample 06-115).

Evidence of a Late Triassic - Middle Jurassic orogenic event are widespread in both the Tibetan Plateau and the Pamir-Karakorum Range; this event, known as Cimmerian Orogeny (Sengör, 1984), led to the final amalgamation of the Cimmerian terranes (i.e. Qiangtang, Amdo, Central Pamir, South Pamir and Karakorum terranes) to the southern margin of Asia (i.e. Songpan-Ganze/Karakul Mazar and Kunlun terranes) through the complete closure of the Paleo-Tethys, and of the smaller Longmu Tso-Shuanghu, Rushan-Pshart and Wakan oceanic basins. The timing of each collision has been mostly determined basing on either stratigraphic or magmatic constraints, whereas metamorphic constraints have been less frequently used. Previous studies have shown that the final collision between each terrane occurred at slightly different ages from west to east. In the central Tibetan Plateau, the final collision of the Qiangtang terrane with the Songpan-Ganze and Kunlun terranes occurred during the Late Triassic - Early Jurassic (e.g. 
Dewey et al., 1988; Matte et al., 1996; Roger et al., 2003, 2010; Dai et al., 2013; Cao et al., 2015; Liu et al., 2015), and the amalgamation of South Qiangtang and North Qiangtang was broadly coeval, independently from the model chosen to explain the nature of the Central Qiangtang Metamorphic Belt (i.e. underthrust model vs intra-Qiangtang suture model, see section 2). In the Pamir-Karakorum Range the accretions of Central Pamir to Karakul Mazar (North Pamir) and of South Pamir to Central Pamir were broadly coeval at ca. $200 \mathrm{Ma}$, i.e. during the latest Triassic - earliest Jurassic (e.g. Gaetani et al., 1993; Zanchi et al., 2000, 2012; Zanchi and Gaetani, 2011; Angiolini et al., 2013; Robinson et al., 2015; Zanchetta et al., 2018), whereas the collision of Karakoram with South Pamir is supposed to be Late Early Jurassic (e.g. Searle and Tirrull, 1991; Gaetani et al., 1993; Angiolini et al., 2013).

In this framework, we therefore interpret the Middle Jurassic xenotime and monazite ages recorded by the two micas phyllite of the Bazar Dara Slates Unit (sample 06-1) to be related to the Cimmerian orogenic event, i.e. to the collision between the Bazar Dara Slates and the Surukwat Complex (Fig. 10); according to the petrologic results, this collisional event was responsible for a greenschist-facies (i.e. $~ 320^{\circ} \mathrm{C}, 5 \mathrm{kbar}$ ) metamorphic overprint in the Bazar Dara Slates Unit (Fig. 11a,b). This is consistent with the stability field of both xenotime and monazite, that can grow in low-grade pelitic schists (Pan, 1997; Wing et al., 2003; Bollinger and Janots, 2006; Janots et al., 2006; Rasmussen et al., 2007; Krenn and Finger, 2007).

Due to the scarcity of xenotime in the metapelite of the Surukwat Complex (sample 06-115), the interpretation of its age and of the P-T conditions of its growth remain uncertain. It has been demonstrated that xenotime remains stable with increasing metamorphic grade in garnet-absent rocks, whereas it reacts out continuously as garnet grows, and is typically gone from the matrix assemblage in samples from the middle garnet zone (Spear and Pyle, 2002; Fitsimons et al., 2005). This constrains the growth of xenotime at temperatures below the first appearance of garnet (i.e. $\mathrm{T}<500^{\circ} \mathrm{C}$ according to the pseudosection modelling in Groppo and Rolfo, 2008) and explains why xenotime is so scarce in the garnet-bearing sample 06-115. The ca. $170 \mathrm{Ma}$ age obtained from the rare xenotime grains in this sample might be thus related to the same Cimmerian orogenic event registered by the Bazar Dara Slates Unit. An alternative hypothesis could be to correlate the ca. $170 \mathrm{Ma}$ age to the earliest stage of development of an accretionary complex on the southern margin of the Surukwat Complex (see below, section 5.1.3; Fig. 11a).

\subsubsection{The Late Jurassic formation of an accretionary prism on the southern margin of the Surukwat Complex} The Surukwat Complex experienced another significant tectono-metamorphic event during the Late Jurassic at ca. $150 \mathrm{Ma}$, responsible for the growth of a first generation of monazite in the metapelite sample 06-115 (two grains: $157 \pm 6 \mathrm{Ma}$ and $144 \pm 4 \mathrm{Ma}$ ). Microstructural observations show that this monazite generation is preserved in garnet, whereas in the matrix it is partially reset by the growth of a younger monazite generation (Fig. 5). It has been demonstrated that the first appearance of monazite in 
metapelitic rocks is strongly influenced by the bulk rock composition, particularly by the $\mathrm{CaO}$ content (e.g. Foster and Parrish, 2003; Wing et al., 2003) and the $\mathrm{CaO} / \mathrm{Na}_{2} \mathrm{O}$ ratio (e.g. Janots et al., 2008), and to a lesser extent by the $\mathrm{Al}_{2} \mathrm{O}_{3}$ content and $\mathrm{FeO} / \mathrm{MgO}$ ratio (e.g. Fitsimons et al., 2005). Janots et al. (2008) demonstrated that in metapelites with low $\mathrm{Ca} / \mathrm{Na}$ ratios (i.e. $\mathrm{CaO} / \mathrm{Na}_{2} \mathrm{O}<0.54$ ), monazite is formed through the complete breakdown of allanite at $\mathrm{T}>580^{\circ} \mathrm{C}$, whereas higher $\mathrm{Ca} / \mathrm{Na}$ ratios enhance the allanite stability towards higher temperatures. The $\mathrm{CaO} / \mathrm{Na}_{2} \mathrm{O}$ ratio of sample $06-115$ is 0.26 (Groppo and Rolfo, 2008), therefore it is likely that in this sample monazite grew at $\mathrm{T}>580^{\circ} \mathrm{C}$, through a reaction such as that proposed by Janots et al. (2008) (i.e. allanite + apatite + Al-Fe-Mg phases $1 \rightarrow$ monazite + anorthite + Al-Fe$\mathrm{Mg}$ phases2, with chlorite and garnet involved as Al-Fe-Mg phase1 and phase2, respectively). Garnet growth was modelled at $\sim 600^{\circ} \mathrm{C}, 9$ kbar (i.e. at peak conditions; Groppo and Rolfo, 2008), therefore we suggest that the ca. $150 \mathrm{Ma}$ registered by monazite grains included in garnet might be associated to the peak metamorphic event, and that monazite formation was nearly coeval with garnet growth (Fig. 11d), as also evidenced by its trace element pattern (Fig. 9b).

To interpret the geodynamic significance of this Late Jurassic metamorphic event, the apparently contrasting anticlockwise and clockwise P-T evolutions inferred for samples 06-115 and 06-10/17 should be considered (Groppo and Rolfo, 2008). Anticlockwise P-T paths at relatively high P-T conditions are characteristic of accretionary systems during the early stages of underflow, as suggested for the Franciscan melange (e.g. Platt, 1975; Cloos, 1985, 1986; Ernst, 1988; Krogh et al., 1994), the Coastal Cordillera of south-central Chile (e.g. Willner et al., 2004; Willner, 2005; Hyppolito et al., 2014) and, possibly, the North America Cordillera (Perchuck et al., 1999). In such geodynamic setting, rocks that were piled up earlier to the hot hanging wall of the subduction channel in the deepest part of the accretionary complex, were metamorphosed at higher temperatures for a given pressure (typically at albite-epidote amphibolite-facies conditions, transitional between high-pressure greenschist facies and eclogite facies; $~ 600-650{ }^{\circ} \mathrm{C}, 8-12$ kbar), compared to material subducted later (Perchuck et al., 1999). In the following accretionary stages, the hanging wall became progressively cooler and isotherms were continuously displaced to greater depth due to the continuous de-hydration of the later subducted material, thus implying that the early subducted rocks were exhumed at temperatures lower than those experienced during subduction, whereas the rocks involved later in the accretionary process recorded a normal clockwise P-T path (e.g. Willner et al., 2004; Willner, 2005; Hyppolito et al., 2014). Anticlockwise P-T metamorphic evolutions related to the inception of subduction are not commonly observed because of the extremely small areas affected by this type of metamorphism ( $\leq$ tens of $\mathrm{km}^{2}$, with thickness of few hundred meters: Wakabayashi, 2004). P-T conditions and evolutions recorded by the studied samples fit well with this geodynamic scenario (Fig. 10e-f, 11c-f). Moreover, it has been recently demonstrated that in similar tectonic settings, the accretionary process did not result in a chaotic mixing, but rather in the formation of a "pseudo"-coherent unit (Hyppolito et al., 
2014). This is also consistent with our observation that the Surukwat Complex consists of a tectonic intermingling of lithological units which nevertheless maintain their internal coherence.

To summarize, we suggest that during the Late Jurassic - Early/Middle Cretaceous, an accretionary prism developed on the southern margin of the Surukwat Complex (Fig. 10e-f). The first material involved in the subduction was a portion of the upper Palaeozoic (?) sedimentary cover (i.e. sample 06-115), which was subducted in a relatively hot environment at ca. $150 \mathrm{Ma}$ (Fig. 11c,d). The successive subduction of the thinned southern portion of the pre-Cambrian basement (i.e. samples 06-10 and 06-17) occurred in a cooler environment, during the early exhumation of the firstly subducted metasedimentary rocks (Fig. $11 \mathrm{e}, \mathrm{f})$.

\subsubsection{The Late Cretaceous collision between the Surukwat Complex and the Lhasa terrane}

The Surukwat Complex registered the last tectono-metamorphic event during the Late Cretaceous: this event is recorded in the metapelite sample 06-115 by the growth of monazite at $66 \pm 2 \mathrm{Ma}$. This second generation of monazite is ubiquitous in the matrix and appears in equilibrium with the main foliation, whose P-T conditions of formation were constrained by Groppo and Rolfo (2008) at $~ 500^{\circ} \mathrm{C}, 5 \mathrm{kbar}$.

Evidence of Late Cretaceous metamorphism has been reported from western Tibet and PamirKarakorum Range and are interpreted as the result of collision between the Lhasa and South Qiangtang terranes (western Tibet) and between the Kohistan-Ladakh and Karakorum terranes (Pamir-Karakorum), respectively. More specifically, in western Tibet, tight constrains on the time of this collision have been recently presented by Liu L. et al. (2017) and Liu D. et al. (2017) basing on the Late Cretaceous age of synorogenic magmatism. In the Pamir-Karakorum Range, the timing of collision between Kohistan-Ladakh and Karakourm has been constrained as Middle to Late Cretaceous basing on stratigraphic data (e.g. Gaetani et al., 1990b, 1993; Robinson et al., 2004; Zanchi and Gaetani, 2011; Gaetani, 2016), age of syn-orogenic magmatism (e.g. Fraser et al., 2001; Heuberger et al., 2007; Searle and Philipps, 2007; Searle, 2011) and metamorphic studies (e.g. Fraser et al., 2001; Streule et al., 2009; Searle, 2011). A complex and long-lasting history of tectonic and magmatic activity associated with the Kohistan-Karakorum suture zone, possibly extending up to Eocene time, is also proposed by Heuberger et al. (2007).

The $66 \pm 2$ Ma monazite age recorded by sample 06-115 can be therefore interpreted as the evidence of this collisional event (Fig. 10g, 11g-h). In this framework, the $83 \pm 1$ Ma zircon age obtained from the porphyric granite of the Aghil Granodiorite body (sample 06-26) is perfectly compatible with a subduction-related syn-orogenic magmatism preceding the final collision between the Surukwat Complex and the Lhasa terrane (Fig. 11g). It is worth noting that Liu L. et al. (2017) obtained very similar results (78$80 \mathrm{Ma}$ ) from granitic rocks collected from the same area. A similar interpretation can be extended also to the $102 \pm 1$ Ma zircon age obtained from the Sughet Granodiorite (sample 06-108): however, the Sughet 
Granodiorite intrusive body is located south of the Karakorum fault and it is therefore not directly correlated to the geodynamic history of the Surukwat Complex (see below, section 5.2).

\subsection{Solving the Tibet-Pamir-Karakorum geopuzzle}

The new field, petrological and geochronological data presented in this paper provide new insights toward a better understanding of the Tibet-Pamir-Karakorum geopuzzle, allowing to correlate the different terranes of Central Tibet with those of the Pamir-Karakorum Range on both sides of the Karakorum fault. We propose that (Fig. 12):

(1) the Bazar Dara Slates Unit might be the equivalent of the Sonpan-Ganze terrane of central Tibet, as already suggested by other authors (e.g. Gaetani et al., 1990a, 1991; Matte et al., 1996; Gaetani, 1997; Schwab et al., 2004; Rolfo et al., 2014) and can be correlated to the Karakul-Mazar terrane of the Pamir-Karakorum Range. Lithological and geochronological data from the Karakul-Mazar terrane of the eastern portion of Northern Pamir are especially similar to those described here for the Bazar Dara Slates Unit. These similarities include: (i) the occurrence of Triassic granitoids intruded in metasedimentary lithologies in both terranes (Robinson et al. 2007; Liu et al., 2015); (ii) the age of metamorphism (ranging from greenschist- to amphibolite-facies conditions) was constrained to be Early to Middle Jurassic (160-200 Ma) in the schists exposed along the Muztaghata massif of eastern Northern Pamir (Robinson et al., 2012) and is remarkably similar to the Middle Jurassic age of $170 \mathrm{Ma}$ registered by the studied sample 06-1, which also experienced greenschist-facies metamorphism. Robinson et al. (2012) interpreted this age as the timing of the collision between the Karakul-Mazar terrane and the Central Pamir during final closure of the Paleo-Tethys Ocean, as well as we interpret the Middle Jurassic age as dating the collision between the Bazar Dara Slates and the Surukwat Complex.

(2) the Surukwat Complex might be correlated to the southern margin of the South Qiangtang terrane of central Tibet (see also Gaetani et al., 1990a, 1991; Rolfo et al., 2014), and shows significant similarities with the tectono-stratigraphy and metamorphic evolution of the Amdo terrane. These similarities include: (i) the occurrence of a Neoproterozoic basement in both the Amdo and Surukwat Complex. In both cases this basement consists of felsic to intermediate gneisses derived from igneous protoliths and of a metasedimentary cover derived from late Palaeozoic sediments deposited in a passive margin setting (Guynn et al., 2006, 2012); (ii) widespread evidence of Jurassic metamorphism preceding the Lhasa-Qiangtang collision. Peak metamorphic conditions in the Amdo terrane vary from $\sim 600^{\circ} \mathrm{C}, 8 \mathrm{kbar}$ (remarkably similar to peak conditions estimated for sample $06-115$ ) to $\sim 700^{\circ} \mathrm{C}, 10 \mathrm{kbar}$, and metamorphic peak has been dated as Early Jurassic (ca. 178 Ma: Guynn et al., 2006, 2013). The Amdo terrane thus experienced peak metamorphism earlier than the Surukwat Complex (ca. $150 \mathrm{Ma}$ ), 
consistently with a diachronous activity of the Bangong-Nunjiang suture zone from east to west (Fig. $12 d-f)$.

Opposite to what preliminary suggested in Groppo and Rolfo (2008), the Surukwat Complex cannot be correlated to the Central Qiangtang Metamorphic Belt (CQMB), for three main reasons: (i) the CQMB mostly consists of a tectonic melange (e.g. Kapp et al., 2000, 2003a), whereas the Surukwat Complex is a coherent portion of an old basement with its original sedimentary cover still preserved; (ii) peak metamorphic conditions in some blocks of the CQMB reached blueschist and eclogite facies conditions (e.g. Kapp et al., 2000, 2003a; Zhang et al., 2006a,b, 2011; Pullen et al., 2008, 2011; Zhang and Tang, 2009; Zhai et al., 2011b; Zhao et al., 2014), thus reflecting a significantly different geothermal gradient with respect to the Surukwat Complex; (iii) the timing of metamorphism in the CQMB is Middle to Late Triassic (244-223 Ma: Pullen et al., 2008, 2011) whereas in the Surukwat Complex it is Late Jurassic (ca. $150 \mathrm{Ma})$.

(3) From a paleogeographic point of view, the Surukwat Complex occupies an intermediate position between the South Qiangtang terrane and the South Pamir terrane (e.g. Robinson, 2015, Chapman et al., 2018 and references therein), preserving different margins of the same micro-plate. The fundamental difference between the Surukwat Complex and South Pamir is that the latter does not show the evidence of Cretaceous metamorphism, having been "protected" from the collision with the Kohistan-Ladakh terrane by the interposed Karakorum terrane (Fig. 12g). Instead, the Karakorum terrane registered an important metamorphic and deformational event during the Late Cretaceous (between 83 and $62 \mathrm{Ma}$ ), that was interpreted as due to the collision with the Kohistan-Ladakh Arc (Fraser et al., 2001).

(4) In this framework, we propose that the non-metamorphic Shaksgam Sedimentary Belt and the Sughet Granodiorite body, now tectonically interposed between the Surukwat Complex and the Karakorum terrane, do not belong neither to the Surukwat Complex nor to the Karakorum terrane, but instead they are part of the South Pamir terrane (see also Robinson, 2009 and Gaetani and Leven, 2014). In other words, their actual location would not reflect their original position in pre-Cenozoic times, but it would be related to the offset effects of the Karakorum fault. This hypothesis is supported by both petrologic and geochronologic data showing that the Shaksgam Sedimentary Belt escaped the Late Cretaceous metamorphic and deformational event experienced by the Surukwat Complex and likely related to the collision with the Lhasa Terrane (Fig. 10g, 12g). Moreover, the $102 \pm 1 \mathrm{Ma}$ zircon age obtained from the Sughet Granodiorite body is perfectly compatible with the Late Cretaceous calcalkaline subduction-related magmatism responsible for the emplacement of large intrusive bodies in South Pamir as well as in the North Karakorum terrane (e.g. Karakorum Batholith, 106-95 Ma) (Debon et al., 1987; Fraser et al., 2001; Schwab et al., 2004; Zanchi and Gaetani, 2011), which has been related to a north-directed low-dipping subduction below Karakorum. 
9

\section{7} 11 1758 13 1759 15 1760 1761 1782 20

\section{Supplementary material}

Supplementary data to this article including (i) phase diagrams supporting the P-T evolution constrained for the studied samples (Fig. SM1) and (ii) the complete set of U-Pb geochronologic data for zircon (Table SM1a), titanite (Table SM1b), monazite (Table SM1c) and xenotime (Table SM1d) can be found online at:

\section{Acknowledgements}

This paper is dedicated to our late colleague and friend Maurizio Gaetani, who devoted most of his scientific career to the study of Karakorum and Pamir and provided constructive comments and suggestion on an earlier version of the manuscript. K. Horkley and J. Gilotti are thanked for providing electron microprobe composition maps of monazite. Three anonymous reviewers are acknowledged for their constructive comments which improved the manuscript.

Fieldwork of F.R. and C.G. was funded by the Italian National Research Council and the Italian Ministry of Foreign Affairs, in the framework of the Ev-K2-CNR Project. Laboratory work was funded by Compagnia di San Paolo (University of Torino, Call 1, Junior PI Grant: TO_Call1_2012_0068), University of Torino (Ricerca Locale, ex-60\% 2016, 2017 funds: ROLF_RILO_16_01, GROC_RILO_17_01), Italian Ministry of University and Research (PRIN 2015, Project $n^{\circ}$ : 015EC9PJ5). 


\section{References}

Aleinikoff, J.A., Schenck, W.S., Plank, M.O., Srogi, L.A., Fanning, C.M., Kamo, S.L., Bosbyshell, H., 2006. Deciphering igneous and metamorphic events in high-grade rocks of the Wilmington Complex, Delaware: Morphology, cathodoluminescence and backscattered electron zoning, and SHRIMP U-Pb geochronology of zircon and monazite. Geological Society of America Bulletin 118, 39-64.

Aleinikoff, J.N., Grauch, R.I., Mazdab, F.K., Kwak, L., Fanning, C.M., Kamo, S.L., 2012. Origin of an unusual monazite-xenotime gneiss, Hudson Highlands, New York: SHRIMP U-Pb geochronology and trace element geochemistry. American Journal of Science 312, 723-765.

Aleinikoff, J.N., Lund, K., Fanning, C.M., 2015. SHRIMP U-Pb and REE data pertaining to the origins of xenotime in Belt Supergroup rocks: evidence for ages of deposition, hydrothermal alteration, and metamorphism. Canadian Journal of Earth Sciences 52, 722-745.

Aleinikoff, J.N., Wintsch, R.P., Tollo, R.P., Unruh, D.M., Fanning C.M., Schmitz, M.D., 2007. Ages and origins of rocks of the Killingworth dome, south-central Connecticut: Implications for the tectonic evolution of southern New England. American Journal of Science 307, 63-118.

Allégre, C.J., Courtillot, V., Tapponnier, P., Hirn, A., Mattauer, M., Coulon, C., Jaeger, J.J., Achache, J., Scharer, U., Marcoux, J., Burg, J.P., Girardeau, J., Armijo, R., Gariepy, C., Gopel, C., Li, T.D., Xiao, X.C., Chang, C.F., Li, G.Q., Lin, B.Y., Teng, J.W., Wang, N.W., Chen, G.M., Han, T.L., Wang, X.B., Den, W.M., Sheng, H.B., Cao, Y.G., Zhou, J., Qiu, H.R., Bao, P.S., Wang, S.C., Wang, B.X., Zhou, Y.X., Ronghua, X., 1984. Structure and evolution of the Himalaya-Tibet orogenic belt. Nature 307, 17-22.

Angiolini, L., Zanchi, A., Zanchetta, S., Nicora, A., Vezzoli, G., 2013. The Cimmerian geopuzzle: new data from South Pamir. Terra Nova 25, 352-360.

Angiolini, L., Zanchi, A., Zanchetta, S., Nicora, A., Vuolo, O., Berra, F., Henderson, C., Malaspina, N., Rettori, R., Vachard, D., Vezzoli, G., 2015. From rift to drift in South Pamir (Tajikistan): Permian evolution of a Cimmerian terrane. Journal of Asian Earth Sciences 102, 146-169.

Barth, A.P., Wooden, J.L., 2006. Timing of magmatism following initial convergence at a passive margin, southwestern US Cordillera, and ages of lower crustal magma sources. Journal of Geology 114, $231-245$.

Barth, A.P., Wooden, J.L., 2010. Coupled elemental and isotopic analyses of polygenetic zircons from granitic rocks by ion microprobe, with implications for melt evolution and the source of granitic magmas. Chemical Geology 277, 149-159.

Black, L.P., Kamo, S.L., Allen, C.M., Davis, D.W., Aleinikoff, J.N., Valley, J.W., Mundil, R., Campbell, I.H., Korsh, R.J., Williams, I.S., and Foudoulis, C., 2004. Improved ${ }^{206} \mathrm{~Pb} /{ }^{238} \mathrm{U}$ microprobe geochronology by monitoring of a trace-element-related matrix effect; SHRIMP, ID-TIMS, ELA-ICP-MS and oxygen isotope documentation for a series of zircon standards. Chemical Geology 205, 115-140.

Bollinger, L., Janots, E., 2006. Evidence for Mio-Pliocene retrograde monazite in the Lesser Himalaya, far western Nepal. European Journal of Mineralogy 18, 289-297. 
Burtman, V.S., Molnar, P., 1993. Geological and geophysical evidence for deep subduction of continental crust beneath the Pamir. Geological Society of America Special Paper 281, 1-76.

Cao, K., Wang, G.C., Bernet, M., van der Beek, P., Zhang, K.X., 2015. Exhumation history of the West Kunlun Mountains, northwestern Tibet: Evidence for a long-lived, rejuvenated orogen. Earth and Planetary Science Letters 432, 391-403.

Chapman, J.B., Robinson, A.C., Carrapa, B., Villarreal, D., Worthington, J., De Celes, P.G., Kapp, P., Gadoev, M., Oimahmadov, I., Gehrels, G., 2018. Cretaceous shortening and exhumation history of the South Pamir terrane. Lithosphere 10, 494-511.

Chen, M, Niu, F., Tromp, J., Lenardic, A., Lee, C.T.A., Cao, W., Ribeiro, J., 2017. Lithospheric foundering and underthrusting imaged beneath Tibet. Nature Communications 8, 15659.

Chung, S.L., Niu, Y., 2016. Recent advances on the tectonic and magmatic evolution of the Greater Tibetan Plateau: A special issue in honor of Prof. Guitang Pan. Lithos 245, 1-6.

Cloos, M., 1985. Thermal evolution of convergent plate margins: thermal modelling and reevaluation of isotopic Ar-ages for blueschist in the Franciscan Complex of California. Tectonics 4, 421-433.

Cloos, M., 1986. Blueschist in the Franciscan Complex of California: petrotectonic constraints on uplift mechanisms. In: Evans, B.W., Browns, E.H. (Eds.), Blueschist and Eclogites. Geological Society of America Memoir 164, 77-93.

Coble, M.A., Vazquez, J., Barth, A.P., Wooden, J., Burns, D., Kylander-Clark, A., Jackson, S., and Vennari, C.E., 2018. Trace Element Characterization of MAD-559 Zircon Reference Material for Ion Microprobe Analysis, Geostandards and Geoanalytical Research 42, 481-497.

Coward, M.P., Kidd, W.S.F., Yun, P., Shackleton, R.M., Hu, Z., 1988. The Structure of the 1985 Tibet Geotraverse, Lhasa to Golmud. Philosophical Transactions of the Royal Society of London Series A Mathematical Physical and Engineering Sciences 327, 307-336.

Cross, A.J., Williams, I.S., 2018. SHRIMP U-Pb-Th xenotime $\left(\mathrm{YPO}_{4}\right)$ geochronology: A novel approach for the correction of SIMS matrix effects. Chemical Geology 484, 81-108.

Dai, J., Wang, C., Hourigan, J., Santosh, M., 2013. Multi-stage tectono-magmatic events of the Eastern Kunlun Range, northern Tibet: Insights from $\mathrm{U}-\mathrm{Pb}$ geochronology and (U-Th)/He thermochronology. Tectonophysics 599, 97-106.

Debon, F., Le Fort, P., Dautel, D., Sonet, J., Zimmermann, J.L., 1987. Granites of western Karakorum and northern Kohistan (Pakistan): A composite mid-Cretaceous to Upper Cenozoic magmatism. Lithos 20, 19-40.

Dewey, J.F., Shackleton, R.M., Chengfa, C., Yiyin, S., 1988. The tectonic evolution of the Tibetan Plateau. Philosophical Transactions of the Royal Society of London 327, 379-413.

Dong, Y., Zhang, G., Neubauer, F., Liu, X., Genser, J., Hauzenberger, C., 2011. Tectonic evolution of the Qinling orogen, China: Review and synthesis. Journal of Asian Earth Sciences 41, 213-237. 
Ernst, W.G., 1988. Tectonic history of subduction zones inferred from retrograde blueschist P-T paths. Geology 16, 1081-1084.

Ferry, J.M., Watson, E.B., 2007. New thermodynamic models and revised calibrations for the Ti-in-zircon and Zr-in-rutile thermometers. Contributions to Mineralogy and Petrology 154, 429-437.

Fitzsimons, I.C.W., Kinny, P.D., Wetherley, S., Hollingsworth, D.A., 2005. Bulk chemical control on metamorphic monazite growth in pelitic schists and implications for U-Pb age data. Journal of Metamorphic Geology 23, 261-277.

Fletcher, I.R., McNaughton, N.J., Aleinikoff, J.N., Rasmussen, B., Kamo, S.L., 2004. Improved calibration procedures and new standards for $\mathrm{U}-\mathrm{Pb}$ and $\mathrm{Th}-\mathrm{Pb}$ dating of Phanerozoic xenotime by ion microprobe. Chemical Geology 209, 295-314.

Fletcher, I.R., McNaughton, N.J., Davis, W.J., Rasmussen, B. 2010. Matrix effects and calibration limitations in ion probe U-Pb and Th-Pb dating of monazite. Chemical Geology 270, 31-44.

Foster, G.L., Parrish, R.R., 2003. Metamorphic monazite and the generation of P-T-t paths. In: Vance, D., Müller, W., Villa, I.M. (Eds.), Geochronology: Linking the Isotopic Record with Petrology and Textures. Geological Society of London Special Publication, London 220, 25-47.

Fraser, J.E., Searle, M.P., Parrish, R.R., Nobel, S.R., 2001. Chronology of deformation, metamorphism, and magmatism in the southern Karakorum Mountains. Geological Society of America Bulletin 113, 14431455.

Gaetani, M., 1997. The Karakorum block in central Asia, from Ordovician to Cretaceous. Sedimentary Geology 109, 339-359.

Gaetani, M., 2016. Blank on the Geological Map. Rendiconti Lincei, Scienze Fisiche e Naturali 27, 181-195.

Gaetani, M., Garzanti, E., Jadoul, F., Nicora, A., Tintori, A., Pasini, M., Khan, K.S.A., 1990b. The north Karakorum side of the Central Asia geopuzzle. Geological Society of America Bulletin 102, 54-62.

Gaetani, M., Gosso, G., Pognante, U., 1990a. A geological transect from Kunlun to Karakorum. (Sinkiang, China): the western termination of the Tibetan Plateau. Preliminary note. Terra Nova 2, 23-30.

Gaetani, M., Gosso, G., Pognante, U., 1991. Geological transect from Kunlun to Karakorum. In: Desio, A. (Ed.), Geodesy, Geophysics and Geology of the Upper Shaksgam Valley (North East Karakorum) and South Sinkiang. Scientific Reports of the Italian Expedition to Karakorum 1988, Prof. A. Desio Leader. Ev K2 CNR, Milano, 99-190.

Gaetani, M., Jadoul, F., Erba, E., Garzanti, E., 1993. Jurassic and Cretaceous orogenic events in the North Karakorum: age constraints from sedimentary rocks. In: Treloar, P.J., Searle, M.P. (Eds.), Himalayan Tectonics. Geological Society of London Special Publication, London 74, 39-52.

Gaetani, M., Leven, E.Y., 2014. The Permian succession of the Shaksgam Valley, Sinkiang (China). Italian Journal of Geosciences 133, 45-62. 
Groppo, C., Rolfo, F., 2008. Counterclockwise P-T evolution of the Aghil Range: Metamorphic record of an accretionary melange between Kunlun and Karakorum (SW Sinkiang, China). Lithos 105, 365-378.

Guynn J., Tropper P., Kapp P., Gehrels G.E., 2013. Metamorphism of the Amdo metamorphic complex, Tibet: implications for the Jurassic tectonic evolution of the Bangong suture zone. Journal of metamorphic Geology 31, 705-727.

Guynn, J., Kapp, P., Gehrels, G., Ding, L., 2012. U-Pb geochronology 1 of basement rocks in central Tibet and paleogeographic implications. Journal of Asian Earth Sciences 43, 23-50.

Guynn, J.H., Kapp, P., Pullen, A., Heizler, M., Gehrels, G., Ding, L., 2006. Tibetan basement rocks near Amdo reveal "missing" Mesozoic tectonism along the Bangong suture, central Tibet. Geology 34, 505-508.

Harris, N.B.W., Xu, R.H., Lewis, C.L., Jin, C.W., 1988. Plutonic rocks of the 1985 Tibet Geotraverse, Lhasa to Golmud. Philosophical Transactions of the Royal Society of London Series A - Mathematical Physical and Engineering Sciences 327, 145-168.

Hayden, L.A., Watson, E.B., 2007. Rutile saturation in hydrous siliceous melts and its bearing on Tithermometry of quartz and zircon. Earth and Planetary Science Letters 258, 561-568.

Heuberger, S., Schaltegger, U., Burg, J.P., Villa, I.M., Frank, M., Dawood, H., Hussain, S., Zanchi, A., 2007. Age and isotopic constraints on magmatism along the Karakorum-Kohistan Suture Zone, NW Pakistan: evidence for subduction and continued convergence after India-Asia collision. Swiss Journal of Geosciences 100, 85-107.

Hildebrand, P.R., Nobel, S.R., Searle, M.P., Waters, D.J., Parrish, R.R., 2001. Old origin for an active mountain range: geology and geochronology of the eastern Hindu Kush, Pakistan. Geological Society of America Bulletin 113, 625-639.

Holland, T.J.B., Powell, R., 1998. An internally consistent thermodynamic data set for phases of petrologic interest. Journal of Metamorphic Geology 16, 309-343.

Hu, D.G., Wu, Z.H., Jiang, W., Shi, Y.R., Ye, P.S., Liu, Q.S., 2005. SHRIMP zircon U-Pb age and Nd isotopic study on the Nyainqêntanglha Group in Tibet. Science in China (Series D: Earth Sciences) 48, 1377-1386.

Hyppolito, T., Garcia-Gasco, A., Juliani, C., Meira, V.T., Hall, C., 2014. Late Paleozoic onset of subduction and exhumation at the western margin of Gondwana (Chilenia Terrane): Counterclockwise P-T paths and timing of metamorphism of deep-seated garnet-mica schist and amphibolite of Punta Sirena, Coastal Accretionary Complex, central Chile (34 S). Lithos 206-207, 409-434.

Ireland, T.R., Williams, I.S., 2003. Considerations in zircon geochronology by SIMS. In: Hanchar, J.M., Hoskin, W.O. (Eds.), Reviews in Mineralogy and Geochemistry 53, 215-241.

Janots, E., Engi, M., Berger, A., Allaz, J., Schwarz, J.O., Spandler, C., 2008. Prograde metamorphic sequence of REE minerals in pelitic rocks of the Central Alps: implications for allanite-monazite-xenotime phase relations from 250 to $610^{\circ} \mathrm{C}$. Journal of metamorphic Geology 26, 509-526. 
Janots, E., Negro, F., Brunet, F., Goffe', B., Engi, M. and Bouybaouene, M. L., 2006. Evolution of the REE mineralogy in HP-LT metapelites of the Sebtide complex, Rif, Morocco: monazite stability and geochronology. Lithos 87, 214-234.

Kapp, P., 2001. Blueschist-bearing metamorphic core complexes in the Qiangtang block reveal deep crustal structure of northern Tibet. Comment and Reply. Geology 29, 91.

Kapp, P., DeCelles, P.G., Gehrels, G.E., Heizler, M., Lin, D., 2007. Geological records of the Lhasa-Qiangtang and Indo-Asian collisions in the Nima area of central Tibet. Geological Society of America Bulletin 119, 917-933.

Kapp, P., Murphy, M.A., Yin, A., Harrison, M., 2003b. Mesozoic and Cenozoic tectonic evolution of the Shiquanhe area of western Tibet. Tectonics 22, 1029.

Kapp, P., Yin, A., Harrison, T.M., Ding, L., 2005. Cretaceous-Tertiary shortening, basin development, and volcanism in central Tibet. Geological Society of America Bulletin 117, 865-878.

Kapp, P., Yin, A., Manning, C.E., Harrison, T.M., Taylor, M., 2003a. Tectonic evolution of the early Mesozoic blueschist-bearing Qiangtang metamorphic belt, central Tibet. Tectonics 22, 1043.

Kapp, P., Yin, A., Manning, C.E., Murphy, M., Harrison, T.M., Spurlin, M., 2000. Blueschist-bearing metamorphic core complexes in the Qiangtang block reveal deep crustal structure of northern Tibet. Geology 28, 19-22.

Krenn, E., Finger, F., 2007. Formation of monazite and rhabdophane at the expense of allanite during Alpine low temperature retrogression of metapelitic basement rocks from Crete, Greece: Microprobe data and geochronological implications. Lithos 95, 130-147.

Krogh, E.J., Oh, C.W., Liou, J.G., 1994. Polyphase and anticlockwise P-T evolution for Franciscan eclogites and blueschists from Jenner, California, USA. Journal of Metamorphic Geology 18, 211-219.

Lacassin, R., Valli, F., Arnaud, N., Leloup, P.H., Paquette, J.L., Haibing, L., Tapponnier, P., Chevalier, M.L., Guillot, S., Maheo, G., Zhiqin, X., 2004. Large-scale geometry, offset and kinematic evolution of the Karakorum fault, Tibet. Earth and Planetary Science Letters 219, 255-269.

Le Fort, P., Tongiorgi, M., Gaetani, M., 1994. Discovery of a crystalline basement and Early Ordovician marine transgression in the Karakorum mountain range, Pakistan. Geology 22, 941-944.

Leeder, M.R., Smith, A.B., Yin, J.X., 1988. Sedimentology, paleoecology and palaeoenvironmental evolution of the 1985 Lhasa to Golmud Geotraverse. Philosophical Transactions of the Royal Society of London Series A, Mathematical Physical and Engineering Sciences 327, 107-143.

Leier, A.L., Kapp, P., Gehrels, G.E., DeCelles, P.G., 2007. Detrital zircon geochronology of CarboniferousCretaceous strata in the Lhasa terrane, Southern Tibet. Basin Research 19, 361-378.

Leloup, P.H., Arnaud, N.O., Maheo, G., Paquette, J.L., Guillot, S., Valli, F., Li, H., Xu, Z., Lacassin, R., Tapponnier, P., 2012. Successive deformation episodes along the Lungmu Co zone, west-central Tibet. Gondwana Research 21, 37-52. 
Leloup, P.H., Boutinnet, E., Davis, W.J., Hattori, K., 2011. Long-lasting intracontinental strike-slip faulting: new evidence from the Karakorum shear zone in the Himalayas. Terra Nova 23, 92-99.

Lemennicier, Y., Le Fort, P., Lombardo, B., Pêcher, A., Rolfo, F. 1996. Tectonometamorphic evolution of the central Karakorum (Baltistan - northern Pakistan). Tectonophysics 260, 119-143.

Liang, X., Wang, G., Yuan, G., Liu, Y., 2012. Structural sequence and geochronology of the Qomo Ri accretionary complex, Central Qiangtang, Tibet: implications for the Late Triassic subduction of the Paleo-Tethys Ocean. Gondwana Research 22, 470-481.

Liu, D., Shi, R., Ding, L., Huang, Q., Zhang, X., Yue, Y., Zhang, L., 2017. Zircon U-Pb age and Hf isotopic compositions of Mesozoic granitoids in southern Qiangtang, Tibet: Implications for the subduction of the Bangong-Nujiang Tethyan Ocean. Gondwana Research 41, 157-1720.

Liu, L., Hou, M., Chen, Y., Tang, H., Xiao, C., 2017. Late Cretaceous granitoids in Karakorum, northwest Tibet: petrogenesis and tectonic implications, International Geology Review 59, 151-165.

Liu, Y., Santosh, M., Zhao, Z.B., Niu, W.C., Wang, G.H., 2011. Evidence for palaeo-Tethyan oceanic subduction within central Qiangtang, northern Tibet. Lithos 127, 39-53.

Liu, Z., Jiang, Y., Jia, R., Zhao, P., Zhou, Q., 2015. Origin of Late Triassic high-K calc-alkaline granitoids and their potassic microgranular enclaves from the western Tibet Plateau, northwest China: implications for Paleo-Tethys evolution. Gondwana Research 27, 326-341.

Ludwig, K.R., 2009. Squid 2, A user's manual. Berkeley Geochronology Center Special Publication No. 5, p. 110.

Ludwig, K.R., 2012. Isoplot 3.75, a geochronological toolkit for Excel. Berkeley Geochronology Center Special Publication No. 5, p. 75.

Matte, P., Tapponnier, P., Arnaud, N., Bourjot, L., Avouac, J.P., Vidal, P., Liu, Q., Pan, Y., Wang, Y., 1996. Tectonics of Western Tibet, between the Tarim and the Indus. Earth and Planetary Science Letters 142, 311-330.

McDonough, W.F., Sun, S.S., 1995. The composition of the Earth. Chemical Geology 120, 223-253.

Murphy, M.A., Yin, A., Harrison, T.M., Dürr, S.B., Chen, Z., Ryerson, F.J., Kidd, W.S.F., Wang, X., Zhou, X., 1997. Did the Indo-Asian collision alone create the Tibetan plateau? Geology 25, 719-722.

Pan, G.T, Ding, J., Yao, D., Wang, L., 2004. Geological Map of the Qinghai-Xizang (Tibet) Plateau and Adjacent Areas. Chengdu Cartographic Publishing House, Chengdu.

Pan, G.T., Wang, L.Q., Li, R.S., Yuan, S.H., Ji, W.H., Yin, F.G., Zhang, W.P., Wang, B.D., 2012. Tectonic evolution of the Qinghai-Tibet Plateau. Journal of Asian Earth Sciences 53, 3-14.

Pan, Y.M., 1997. Zircon- and monazite-forming metamorphic reactions at Manitouwadge, Ontario. Canadian Mineralogist 35, 105-118. 
Perchuk, A., Philippot, P., Erdmer, P., Fialin, M., 1999. Rates of thermal equilibration at the onset of subduction deduced from diffusion modelling of eclogitic garnets, Yukon-Tanana terrane, Canada. Geology 27, 531-534.

Phillips, R.J., 2008. Geological map of the Karakoram fault zone, Eastern Karakoram, Ladakh, NW Himalaya. Journal of Maps 4, 21-37.

Phillips, R.J., Parrish, R.R., Searle, M.P., 2004. Age constraints on ductile deformation and long-term slip rates along the Karakoram fault zone, Ladakh. Earth and Planetary Science Letters 226, 305-319.

Platt, J.P., 1975. Metamorphism and deformational processes in the Franciscan Complex, California. Some insights from the Catalina schists terrane. Geological Society of America Bullettin 86, 1337-1347.

Pouchou, J.L., Pichoir, F., 1988. Determination of mass absorption coefficients for soft Xrays by use of the electron microprobe. Microbeam Analysis. San Francisco Press, pp. 319-324.

Powell, R., Holland, T.J.B., 1994. Optimal geothermometry and geobarometry. American Mineralogist 79, 120-133.

Pullen, A., Kapp, P., Gehrels, G.E., Ding, L., Zhang, Q., 2011. Metamorphic rocks in central Tibet: lateral variations and implications for crustal structure. Geological Society of America Bulletin 123, 585-600.

Pullen, A., Kapp, P., Gehrels, G.E., Vervoort, J.D., Lin, D., 2008. Triassic continental subduction in central Tibet and Mediterranean-style closure of the Paleo-Tethys Ocean. Geology 36, 351-354.

Rasmussen, B., Fletcher, I.R., Muhling, J.R., 2007. In situ U-Pb dating and element mapping of three generations of monazite: unravelling cryptic tectonothermal events in low-grade terranes. Geochimica et Cosmochimica Acta 71, 670-690.

Robinson, A.C., 2009. Geologic offsets across the northern Karakorum fault: implications for its role and terrane correlations in the western Himalayan- Tibetan orogen. Earth and Planetary Science Letters 279, 123-130.

Robinson, A.C., 2015. Mesozoic tectonics of the Gondwanan terranes of the pamir plateau. Journal of Asian Earth Sciences 102, 170-179.

Robinson, A.C., Ducea, M., Lapen, T.J., 2012. Detrital zircon and isotopic constraints on the crustal architecture and tectonic evolution of the northeastern Pamir. Tectonics 31, TC2016.

Robinson, A.C., Yin, A., Manning, C.E., Harrison, M., Zhang, S.H., Wang, X.F., 2007. Cenozoic evolution of the eastern Pamir: Implications for strain-accommodation mechanisms at the western end of the Himalayan-Tibetan orogeny. Geological Society of America Bulletin 119, 882-896.

Robinson, A.C., Yin, A., Manning, C.E., Harrison, T.M., Zhang, S.-H., Wang, X.-F., 2004. Tectonic evolution of the northeastern Pamir: constraints from the northern portion of the Cenozoic Kongur Shan extensional system. Geological Society of America Bulletin 116, 953-974. 
Roger, F., Arnaud, N., Gilder, S., Tapponnier, P., Jolivet, M., Brunel, M., Malavieille, J., Xu, Z., 2003. Geochronological and geochemical constraints on Mesozoic suturing in East Central Tibet. Tectonics 22, 1037.

Roger, F., Calassou, S., 1997. U-Pb geochronology on zircon and isotopic geochemistry (Pb, $\mathrm{Sr}, \mathrm{Nd})$ of basement in the Songpan-Garze fold belt (China). Comptes Rendus de I'Académie des Sciences Paris $324,819-826$.

Roger, F., Jolivet, M., Malavieille, J., 2010. The tectonic evolution of the Songpan-Garzê (North Tibet) and adjacent areas from Proterozoic to Present: a synthesis. Journal of Asian Earth Sciences 39, 254-269.

Rolfo, F., Groppo, C., Gaetani, M., 2014. A geological cross-section north of Karakorum, from Yarkand to K2. In: Montomoli, C., Carosi, R., Law, R., Singh, S., Ra,i S.M. (Eds.), Geological field trips in the Himalaya, Karakoram and Tibet. Journal of the Virtual Explorer, Electronic Edition, 47, paper 1.

Rolfo, F., Lombardo, B., Compagnoni, R., Le Fort, P., Lemennicier, Y., Pêcher, A., 1997. Geology and Metamorphism of the Ladakh Terrane and Shyok Suture Zone in the Chogo Lungma - Turmik area (northern Pakistan). Geodinamica Acta 10/5, 251-270.

Rubatto, D., Chakraborty, S., Dasgupta, S., 2013. Timescales of crustal melting in the Higher Himalayan Crystallines (Sikkim, Eastern Himalaya) inferred from trace element-constrained monazite and zircon chronology. Contribution to Mineralogy and Petrology 165, 349-372.

Schoene, B., Borwing, S.A., 2006. U-Pb systematics of the McClure Mountain syenite: thermochronological constraints on the age of the ${ }^{40} \mathrm{Ar}^{-39} \mathrm{Ar}$ standard MMhb. Contributions to Mineralogy and Petrology 151, 615-630.

Schwab, M., Ratschbacher, L., Siebel, W., McWilliams, M., Minaev, V., Lutkov, V., Chen, F., Stanek, K., Nelson, B., Frisch, W., Wooden, J.L., 2004. Assembly of the Pamirs: Age and origin of magmatic belts from the southern Tien Shan to the southern Pamirs and their relation to Tibet. Tectonics 23, TC4002.

Searle, M.P., 2011. Geological evolution of the Karakoram Ranges. Italian Journal of Geosciences 130, 147159.

Searle, M.P., Elliott J.R., Phillips R.J, Chung S.L., 2011. Crustal-lithospheric structure and continental extrusion of Tibet. Journal of the Geological Society of London 168, 633-672.

Searle, M.P., Parrish, R.R., Thow, A.V., Noble, S.R., Phillips, R.J. and Waters, D.J. 2010. Anatomy, age and evolution of a collisional mountain belt: the Baltoro granite batholith and Karakoram Metamorphic complex, Pakistani Karakoram. Journal of the Geological Society of London 167, 183-202.

Searle, M.P., Phillips, R.J., 2007. Relationships between right-lateral shear along the Karakoram fault and metamorphism, magmatism, exhumation and uplift: evidence from the K2-Gasherbrum-Pangong ranges, north Pakistan and Ladakh. Journal of Geological Society of London 164, 439-450.

Searle, M.P., Tirrul, R. 1991. Structural and thermal evolution of the Karakoram crust. Journal of the Geological Society of London 148, 65-82. 
Sengör, A.M.C., 1979. Mid-Mesozoic closure of Tethys and its implications. Nature 279, 590-593.

Sengör, A.M.C., 1984. The Cimmeride orogenic system and the tectonics of Eurasia. Geological Society of America Special Paper 195, 1-82.

Sengör, A.M.C., 1987. Tectonics of the tethysides: orogenic collage development in a collisional setting. Annual Review of Earth and Planetary Sciences 15, 213-244.

Shi, R.D., 2007. SHRIMP dating of the Bangong Lake SSZ-type ophiolite: constraints on the closure time of ocean in the Bangong Lake-Nujiang River, northwestern Tibet. Chinese Science Bulletin 52, 936-941.

Shi, R.D., Yang, J.S., Xu, Z.Q., Qi, X.X., 2004. Discovery of the boninite series volcanic rocks in the Bangong Lake ophiolite mélange, western Tibet, and its tectonic implications. Chinese Science Bulletin 49, $1272-$ 1278.

Spear, F.S., Pyle, J.M., 2002. Apatite, monazite, and xenotime in metamorphic rocks. In: Kohn, M.J., Rakovan, J., Hughes, J.M. (Eds.), Phosphates: Geochemical, Geobiological, and Materials Importance. Reviews in Mineralogy and Geochemistry, 48. Mineralogical Society of America, Washington, D.C., pp. 293-335.

Stacey, J.S., Kramers, J.D., 1975. Approximation of terrestrial lead isotope evolution by a two-stage model.Earth and Planetary Science Letters 26, 207-221.

Streule, M.J., Phillips, R.J., Searle, M.P., Waters, D.J., Horstwood, M.S.A., 2009. Evolution and chronology of the Pangong Metamorphic Complex adjacent to the Karakoram Fault, Ladakh: constraints from thermobarometry, metamorphic modelling and U-Pb geochronology. Journal of Geological Society of London 166, 919-932.

Upadhyay, R., Rai, J., Sinha, A.K., 2005. New record of Bathonian-Callovian calcareous nannofossils in the eastern Karakoram block: a possible clue to understanding the dextral offset along the Karakoram Fault. Terra Nova 17, 149-157.

Valli, F., Leloup, P.H., Paquette, J.-L., Arnaud, N., Li, H., Tapponnier, P., Lacassin, R., Guillot, S., Liu, D., Deloule, E., Xu, Z., Mahéo, G., 2008. New U/Pb constraints on timing of shearing and long-term slip-rate on the Karakorum fault. Tectonics 27 (5), TC5007.

Wakabayashi, J., 2004. Tectonic mechanisms associated with P-T paths of regional metamorphism: alternatives to single-cycle thrusting and heating. Tectonophysics 392, 193-218.

Watson, E.B., Harrison, T.M., 2005. Zircon thermometer reveals minimum melting conditions on earliest Earth. Science 308, 841-844.

Williams, I.S., 1998. U-Pb by ion microprobe. In: McKibben, M.A., Shanks, W.C. and Ridley, W.I. (Eds.), Applications of microanalytical techniques to understanding mineralizing processes. Society of Economic Geologists, Reviews in Economic Geology 7, 1-35.

Willner, A.P., 2005. Pressure-Temperature Evolution of a Late Palaeozoic Paired Metamorphic Belt in North-Central Chile ( $34^{\circ}-35^{\circ} 30^{\prime}$ S). Journal of Petrology 46, 105-1833. 
Willner, A.P., Glodny, J., Gerya, T.V., Godoy, E., Massonne, H.J., 2004. A counterclockwise PTt path of high pressure/low temperature rocks from Coastal Cordillera accretionary complex of south-central Chile: constraints for the earliest stage of subduction mass flow. Lithos $75,283-310$.

Wing, B.A., Ferry, J.M., Harrison, T.M., 2003. Prograde destruction and formation of monazite and allanite during contact and regional metamorphism of pelites: petrology and geochronology. Contributions to Mineralogy and Petrology 145, 228-250.

Xiao, W.J., Windley, B.F., Chen, H.L., Zhang, G.C., Li, J.L., 2002. Carboniferous-Triassic subduction and accretion in the western Kunlun, China: implications for the collisional and accretionary tectonics of the northern Tibetan Plateau. Geology 30, 295-298.

Xu, R.H., Schaerer, U., Allegre, C.J., 1985. Magmatism and metamorphism in the Lhasa Block (Tibet); a geochronological study. Journal of Geology 93, 41-57.

Yang, Y., Guo, Z., Luo, Y., 2017. Middle-Jurassic tectonostratigraphic evolution of Central Asia, implications for the collision of the Karakoram-Lhasa Block with Asia. Earth Science Reviews 166, 83-110.

Yin, A., Harrison, T.M., 2000. Geologic evolution of the Himalayan-Tibetan orogen. Annual Review of Earth Planetary Science 28, 211-280.

Zanchetta, S., Worthington, J., Angiolini, L., Leven, E.J., Villa, I.M., Zanchi, A., 2018. The Bashgumbaz Complex (Tajikistan): Arc obduction in the Cimmerian orogeny of the Pamir. Gondwana Research 57, 170-190.

Zanchi, A., Fürsich, F.T., Santosh, M., 2015. Cimmerian terranes: Preface. Journal of Asian Earth Sciences $102,1-3$.

Zanchi, A., Gaetani, M., 2011. The geology of the Karakoram range, Pakistan: the new 1:100,000 geological map of Central-Western Karakoram. Italian Journal of Geosciences 130, 161-262.

Zanchi, A., Poli, S., Fumagalli, P., Gaetani, M., 2000. Mantle exhumation along the Tirich Mir Fault Zone, NW Pakistan: pre-mid-Cretaceous accretion of the Karakoram terrane to the Asian margin. In: Khan, M.A., Treloar, P.J., Searle, M.P., Jan, M.Q. (Eds.), Tectonics of the Nanga Parbat Syntaxis and the Western Himalaya. Geological Society of London. Special Publications, London 170, 219-236.

Zanchi, A., Zanchetta, S., Angiolini, L., Vezzoli, G., 2012. Is SE-Pamir a Cimmerian Block? Rendiconti Online Società Geologica Italiana 22, 239-242.

Zeng, M., Zhang, X., Cao, H., Ettensohn, F.R., Cheng, W., Lang, X., 2016. Late Triassic initial subduction of the Bangong-Nujiang Ocean beneath Qiangtang revealed: stratigraphic and geochronological evidence from Gaize, Tibet. Basin Research 28, 147-157.

Zhai, Q.G., Jahn, B.M., Wang, J., Su, L., Mo, X.X., Wang, K.L., Tang, S.H., Lee, H.Y., 2013. The Carboniferous ophiolite in the middle of the Qiangtang terrane, Northern Tibet: SHRIMP U-Pb dating, geochemical and Sr-Nd-Hf isotopic characteristics. Lithos 168, 186-199. 
Zhai, Q.G., Jahn, B.M., Zhang, R.Y., Wang, J., Su, L., 2011a. Triassic subduction of the Paleo-Tethys in northern Tibet, China: evidence from the geochemical and isotopic characteristics of eclogites and blueschists of the Qiangtang block. Journal of Asian Earth Sciences 42, 1356-1370.

Zhai, Q.G., Zhang, R.Y., Jahn, B.M., Li, C., Song, S.G., Wang, J., 2011b. Triassic eclogites from central Qiangtang, northern Tibet, China: petrology, geochronology and metamorphic P-T path. Lithos 125, 173-189.

Zhang K.J., Zhang Y.X., Tang X.C., Xie Y.W., Sha S.L., Peng X.J., 2008. First report of eclogites from central Tibet, China: evidence for ultradeep continental subduction prior to the Cenozoic India-Asian collision. Terra Nova 20, 302-308.

Zhang, K.J., 2001. Blueschist-bearing metamorphic core complexes in the Qiangtang block reveal deep crustal structure of northern Tibet: comment and reply. Geology 29, 90.

Zhang, K.J., Cai, J.X., Zhang, Y.X., Zhao, T.P., 2006a. Eclogites from central Qiangtang, northern Tibet (China) and tectonic implications. Earth and Planetary Science Letters 245, 722-729.

Zhang, K.J., Tang, X.C., 2009. Eclogites in the interior of the Tibetan plateau and their geodynamic implications. Chinese Science Bulletin 54, 2556-2567.

Zhang, K.J., Tang, X.C., Wang, Y., Zhang, Y.X., 2011. Geochronology, geochemistry, and Nd isotopes of early Mesozoic bimodal volcanism in northern Tibet, western China: constraints on the exhumation of the central Qiangtang metamorphic belt. Lithos 121, 167-175.

Zhang, K.J., Zhang, Y.X., Li, B., Zhu, Y.T., Wei, R.Z., 2006b. The blueschist-bearing Qiangtang metamorphic belt (northern Tibet, China) as an in situ suture zone: evidence from geochemical comparison with the Jinsa suture. Geology 34, 493-496.

Zhang, K.J., Zhang, Y.X., Tang, X.C., Xia, B., 2012. Late Mesozoic tectonic evolution and growth of the Tibetan plateau prior to the Indo-Asian collision. Earth Science Reviews 114, 236-249.

Zhang, Y., Niu, Y., Hu, Y., Liu, J., Ye, L., Kong, J., Duan, M., 2016. The syncollisional granitoid magmatism and continental crust growth in the West Kunlun Orogen, China - Evidence from geochronology and geochemistry of the Arkarz pluton. Lithos 245, 191-204.

Zhang, Z., Ding, L., Zhao, Z., Santosh, M., 2017. Tectonic evolution and dynamics of the Tibetan Plateau. Gondwana Research 41, 1-8.

Zhang, Z., Dong, X., Liu, F., Lin, Y., Yan, R., He, Z., Santosh, M., 2012b. The making of Gondwana: Discovery of 650Ma HP granulites from the North Lhasa, Tibet. Precambrian Research 212-213, 107-116.

Zhang, Z., Dong, X., Liu, F., Lin, Y., Yan, R., Santosh, M., 2012a. Tectonic Evolution of the Amdo Terrane, Central Tibet: Petrochemistry and Zircon U-Pb Geochronology. The Journal of Geology 120, 431-451.

Zhang, Z., Dong, X., Santosh, M., Zhao, G., 2014. Metamorphism and tectonic evolution of the Lhasa terrane, Central Tibet. Gondwana Research 25, 170-189. 
Zhang, Z., Santosh, M., 2012. Tectonic evolution of Tibet and surrounding regions. Gondwana Research 21, $1-3$.

Zhao, Z., Bons, P.B., Wang, G., Liu, Y., Zheng, Y., 2014. Origin and pre-Cenozoic evolution of the south Qiangtang basement, Central Tibet. Tectonophysics 623, 52-66.

Zhou, M.F., Ma, Y., Yan, D.P., Xia, X., Zhao, J.H., Sun, M., 2006b. The Yanbian terrane (Southern Sichuan province, SW China): a Neoproterozoic arc assemblage in the western margin of the Yangtze block. Precambrian Research 144, 19-38.

Zhou, M.F., Yan, D.P., Kennedy, A.K., Li, Y., Ding, J., 2002. SHRIMP U-Pb zircon geochronological and geochemical evidence for Neoproterozoic arc-magmatism along the western margin of the Yangtze block, South China. Earth and Planetary Science Letters 196, 51-67.

Zhou, M.F., Yan, D.P., Wang, C.L., Qi, L., Kennedy, A., 2006a. Subduction-related origin of the 750 Ma Xuelongbao adakitic complex (Sichuan province, China): implications for the tectonic setting of the giant Neoproterozoic magmatic event in South China. Earth and Planetary Science Letters 248, 286-300.

Zhu, D.C., Zhao, Z.D., Niu, Y., Dilek, Y., Hou, Z.Q., Mo, X.X., 2013. The origin and pre-Cenozoic evolution of the Tibetan Plateau. Gondwana Research 23, 1429-1454.

Zhu, D.C., Zhao, Z.D., Niu, Y.L., Mo, X.X., Chung, S.L., Hou, Z.Q., Wang, L.Q., Wu, F.Y., 2011a. The Lhasa Terrane: record of a microcontinent and its histories of drift and growth. Earth and Planetary Science Letters 301, 241-255. 
Fig. 1 - (a) Simplified tectonic map of the central-western Tibetan Plateau and Pamir-Karakorum Range (modified after Gaetani et al., 1991 and Robinson, 2009), with location of the Aghil Range (black rectangle). From north to south, the main terranes and sutures of the Tibetan Plateau are TB: Tarim Basin; KL: Kunlun; SG: Songpan-Ganze; NQ: North Qiangtang; SQ: South Qiangtang; LH: Lhasa; I: India; KS: Kunlun Suture; JS: Jinsha Suture; LSSZ: Longmu Tso-Shuanghu Suture Zone; BNSZ: Bangong-Nunjiang Suture Zone; ITSZ: IndusTsangpo Suture Zone, whereas those of the Pamir- Karakorum Range are KM: Karakul-Mazar (North Pamir); CP: Central Pamir; SP: South Pamir; KK: Karakorum; KH/LK: Kohistan-Ladakh; TS: Tanymas Suture; RPSZ: Rushan-Pshart Suture Zone; TBZ: Tirich Boundary Zone; SSZ: Shyok Suture Zone. KKF: Karakorum Fault; KF: Karakax Fault; LCF/ATF: Longmu Co Fault / Althyn Tagh Fault. (b) Geologic map of the Aghil Range, between Kunlun (Yarkand River) and Karakorum (Shaksgam River), modified after Gaetani et al. (1991) and Rolfo et al. (2014), with location of the studied samples (black stars). (c) Sketch of the pre-Mesozoic original relationships between the crystalline basement and the sedimentary cover of the Surukwat Complex. (d) Geologic cross-section from llik to Sughet Jagal (A-B in (b)), with location of the studied samples (white stars).

Fig. 2 - Representative microstructures of the studied samples. Bazar Dara Slates Unit - Sample 06-1: (a) Two-micas + chlorite phyllite: the main foliation $\mathrm{S}_{\mathrm{m}}$, defined by white mica + chlorite + biotite + ilmenite, is locally pervasively crenulated with the appearance of an $S_{m+1}$ defined by white mica + ilmenite. Plane Polarized Light (PPL). Surukwat Complex - Sample 06-10: (b) The mylonitic foliation, defined by phengite, wraps around pluri-mm amphibole porphyroclasts (PPL). (c) Detail of an amphibole porphyroclast: the brownish-green amphibole core $\left(A m p_{1}\right)$ is a relic of the igneous protolith and it is rimmed by a green metamorphic actinolite (Amp $\mathrm{Am}_{2}$ (PPL). Sample 07-17: (d) The porphyric structure of the dioritic protolith is still preserved (note the $\mathrm{mm}$-sized amphibole porphyroblasts set in a fine-grained matrix of albite + epidote + biotite \pm chlorite) (PPL). (e, f) Details of strongly zoned amphibole crystals, with a dark green core (Amp ${ }_{1}$, magmatic hornblende), a light green rim ( $\mathrm{Amp}_{2}$, metamorphic actinolite) and a discontinuous deep green outermost rim ( $\mathrm{Amp}_{3}$, metamorphic hornblende) (PPL). Sample 06-115: (g) The main foliation $\mathrm{S}_{\mathrm{m}}$, defined by white mica + biotite, wraps around $\mathrm{mm}$-sized garnet porphyroblasts. An earlier $\mathrm{S}_{\mathrm{m}-1}$ is preserved in the microlithons and as an internal foliation within garnet. Chlorite porphyroblasts overgrows the $S_{m}(P P L)$. Plutonic bodies - Sample 06-26: (h) This porphyritic granite is characterized by $\mathrm{cm}$-sized perthitic Kfeldspar; biotite is fresh and plagioclase is slightly zoned (Crossed Polarized Light: XPL). Sample 06-108: (i) In this biotite-bearing granodiorite, $\mathrm{K}$-feldspar is poikilitic and biotite is mostly replaced by chlorite (XPL). 
Fig. 3 - BSE images of monazite $(\mathbf{a}, \mathbf{b})$ and xenotime $(\mathbf{c}, \mathbf{d})$ in sample 06-1 showing location of U/Pb-TE analysis. Scale bar in all images is $50 \mu \mathrm{m}$.

Fig. 4 - BSE images of titanite from samples 06-10 (a) and 06-17 (b-d) showing location of U/Pb analysis.

Fig. 5 - BSE images (a-c) and compositional maps (d) of monazite from sample 06-115 showing location of $\mathrm{U} / \mathrm{Pb}-\mathrm{TE}$ analysis. Monazite grains in (a) are included within garnet and yield Jurassic $\mathrm{U} / \mathrm{Pb}$ ages. Matrix monazite grains $(b-c)$ are Late Cretaceous in age. Matrix monazite that displays core to rim zoning in Th (see 4-2.2 and 6-1.1 in d) gives older $\mathrm{U} / \mathrm{Pb}$ ages interpreted to reflect incomplete recrystallization of Jurassic monazite.

Fig. 6 - Cathodoluminescence (CL) images of zircons from samples 06-108 (a) and 06-26 (b) showing location of $\mathrm{U} / \mathrm{Pb}-\mathrm{TE}$ analysis (large circle) and additional TE analysis (small circle).

Fig. 7 - Tera-Wasserburg plots of $\mathrm{U} / \mathrm{Pb}$ data and plots of chondrite normalized trace element data from zircon in samples 06-26 (a) and 06-108 (b). Black ellipses and black symbols in chondrite normalized plots are used in age interpretation; gray ellipses are not. Ellipses plotted at $1 \sigma$. Age uncertainties reported at 95\% confidence level (MSWD = mean square of weighted deviates). Tera-Wasserburg diagrams were made using Isoplot (Ludwig, 2003). Chondrite normalized plots were calculated using values from McDonough and Sun (1995).

Fig. 8 - Tera-Wasserburg plots of U/Pb data from titanite in samples 06-17 (a) and 06-10 (b). Ellipses are plotted at $1 \sigma$. Lower intercept age uncertainties reported at $95 \%$ confidence level (MSWD $=$ mean square of weighted deviates). Tera-Wasserburg diagrams were made using Isoplot (Ludwig, 2003).

Fig. 9 - Tera-Wasserburg plots of $\mathrm{U} / \mathrm{Pb}$ data and plots of chondrite normalized trace element data from xenotime, sample 06-1 (a) and monazite, sample 06-115 (b). Black ellipses and black symbols in chondrite normalized plots are used in age interpretation; gray ellipses are not. Ellipses plotted at $1 \sigma$. Analysis 5-2.1 is not plotted in (b) due large uncertainty in the ${ }^{207} \mathrm{~Pb} /{ }^{206} \mathrm{~Pb}$ ratio. Age uncertainties reported at $95 \%$ confidence level (MSWD = mean square of weighted deviates). Tera-Wasserburg diagrams were made using Isoplot (Ludwig, 2003). Chondrite normalized plots were calculated using values from McDonough and Sun (1995).

Fig. 10 - Pre-Cenozoic tectonic evolution of Western Tibetan Plateau as inferred from geochronological and petrological data discussed in this paper. The sketch is especially focused on the evolution of the Surukwat 
Complex, whereas it is simplified for the other terranes. Abbreviations for the western Tibet terranes and for the interposed oceans are: KL: Kunlun; BDs: Bazar Dara Slates Unit; SC: Surukwat Complex; LH: Lhasa; I: India; PT: Paleo-Tethys; BN: Bangong-Nunjian Ocean; NT: Neo-Tethys. Abbreviations for suture zones are: KS: Kunlun Suture; JS: Jinsha Suture; BNSZ: Bangong-Nunjian Suture Zone. The black rectangle refers to Fig. 11.

Fig. 11 - Enlargement of Fig. 10 focusing on the Mesozoic evolution of the Surukwat Complex and explaining the development of the accretionary wedge on its southern margin $(\mathbf{a}, \mathbf{c}, \mathbf{e}, \mathbf{g})$. Colour codes are the same as in Fig. 10. The P-T diagrams in (b, $\mathbf{d}, \mathbf{f}, \mathbf{h})$ show the peak P-T conditions experienced by the Bazar Dara Slates (b) and by the different thrust sheets of the Surukwat Complex (d, f, h) as inferred from the Average PT results (with $1 \sigma$ error ellipses). The P-T path of sample 06-115 is derived from Groppo and Rolfo (2008), whereas that for sample 06-10 is tentatively inferred basing on the Average PT results.

Fig. 12 - (a-h) Simplified paleogeographic sketches showing the relative positions of the Cimmerian Terranes in pre-Cenozoic times, as inferred from the data presented in this paper. The separation between Central Pamir, South Pamir and Karakorum terranes in the Pamir-Karakorum Range is in agreement with one of the possible configurations proposed by Robinson (2015). The tectonic evolution of North Qiangtang and South Qiangtang terranes follows the in situ suture model (e.g. Zhang et al., 2006a,b, 2011); however, the alternative underthurst model interpretation (e.g. Kapp et al., 2000, 2003a; Kapp, 2001) does not significantly influence the paleogeographic reconstruction of western Tibet (see text for further discussion). The dotted grey line in each diagram refers to the location of Fig. 10 for the same time intervals. The black rectangle in (h) locates the study area in the framework of western Tibet, which is enlarged in (i). (i) Proposed correlation between metamorphic and magmatic terranes of western Tibet and those of Central Tibet and Pamir-Karakorum. The Bazar Dara Slates unit (BDS) is correlated to the Karakul Mazar terrane, the Surukwat Complex (SC) and the Aghil Granodiorite (AG) body are correlated to the South Qiangtang terrane, whereas the Shaksgam Sedimentary Belt (SSB) and the Sughet Granodiorite (SG) body are correlated to the South Pamir terrane. Abbreviations for the other terranes, oceans and sutures are as follows: KL: Kunlun; SG: Songpan-Ganze; KM: Karakul-Mazar; NQ: North Qiangtang; SQ: South Qiangtang; A: Amdo; CP: Central Pamir; SP: South Pamir; KK: Karakorum; LH: Lhasa; KH/LK: KohistanLadakh; I: India; KS: Kunlun Suture; JS: Jinsha Suture; TS: Tanymas Suture; LSSZ: Longmu Tso-Shuanghu Suture Zone; RPSZ: Rushan-Pshart Suture Zone; TBZ: Tirich Boundary Zone; BNSZ: Bangong-Nunjiang Suture Zone; SSZ: Shyok Suture Zone; ITSZ: Indus-Tsangpo Suture Zone; KKF: Karakorum Fault; KF: Karakax Fault; LCF/ATF: Longmu Co Fault / Althyn Tagh Fault. 


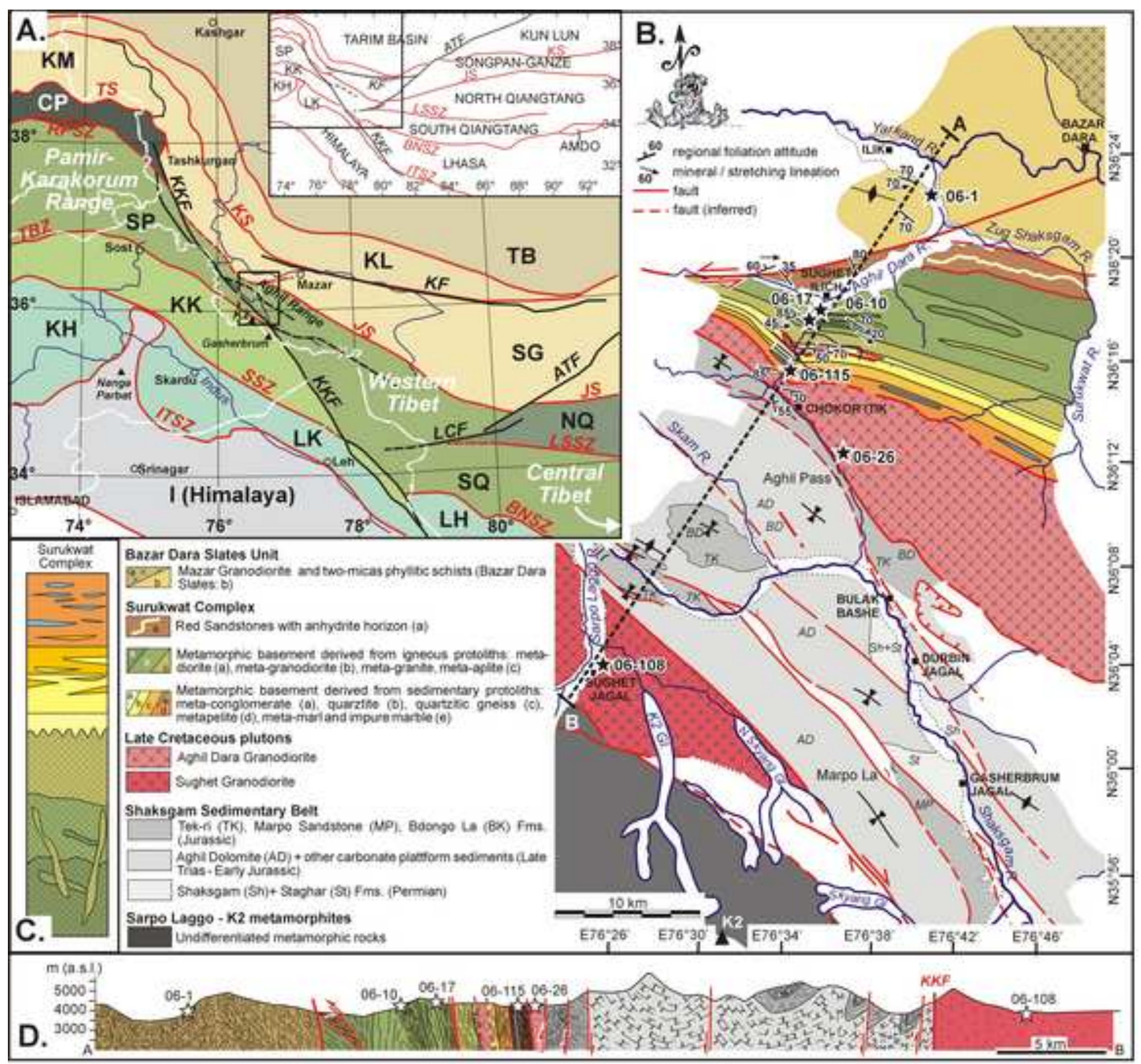


Click here to download high resolution image
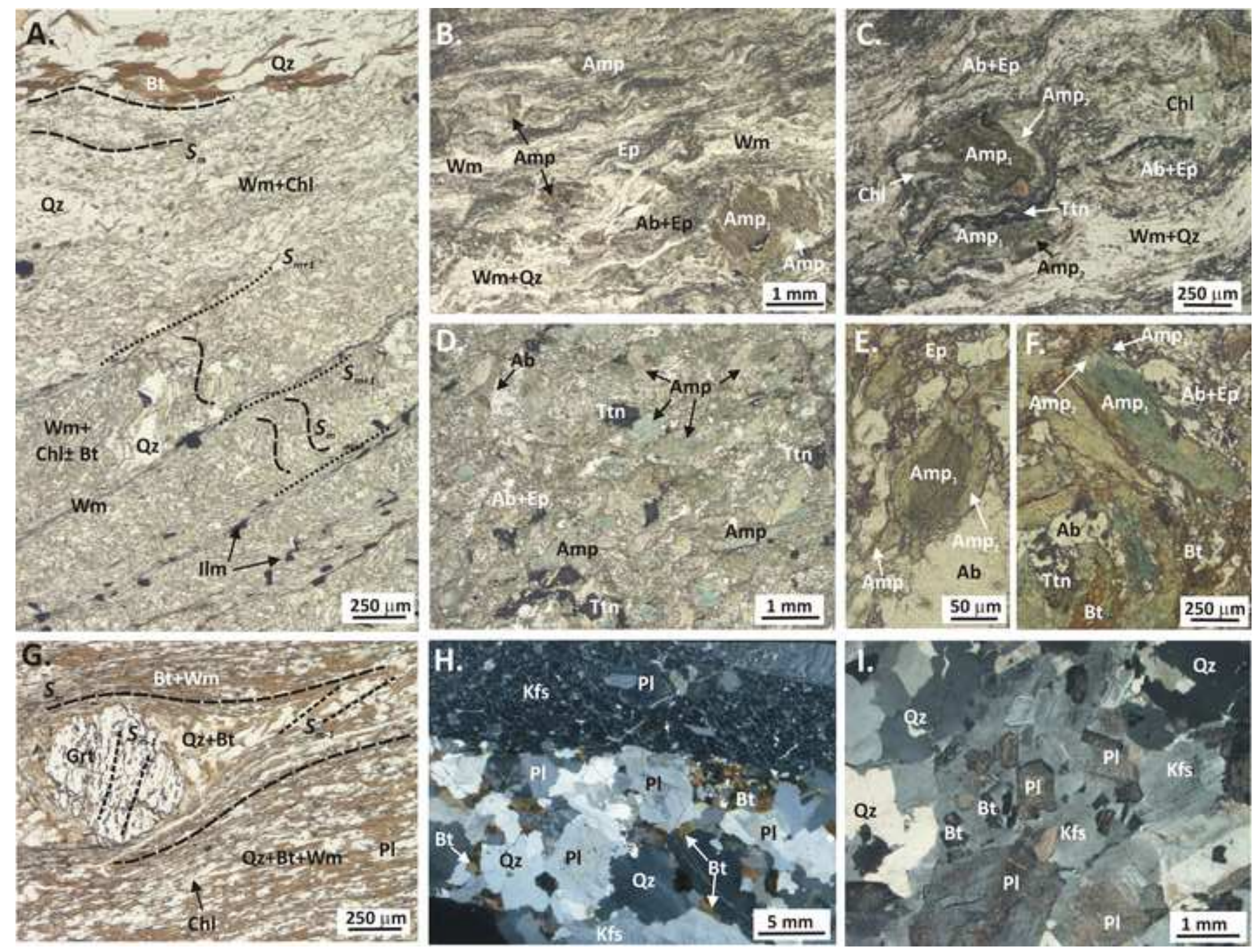


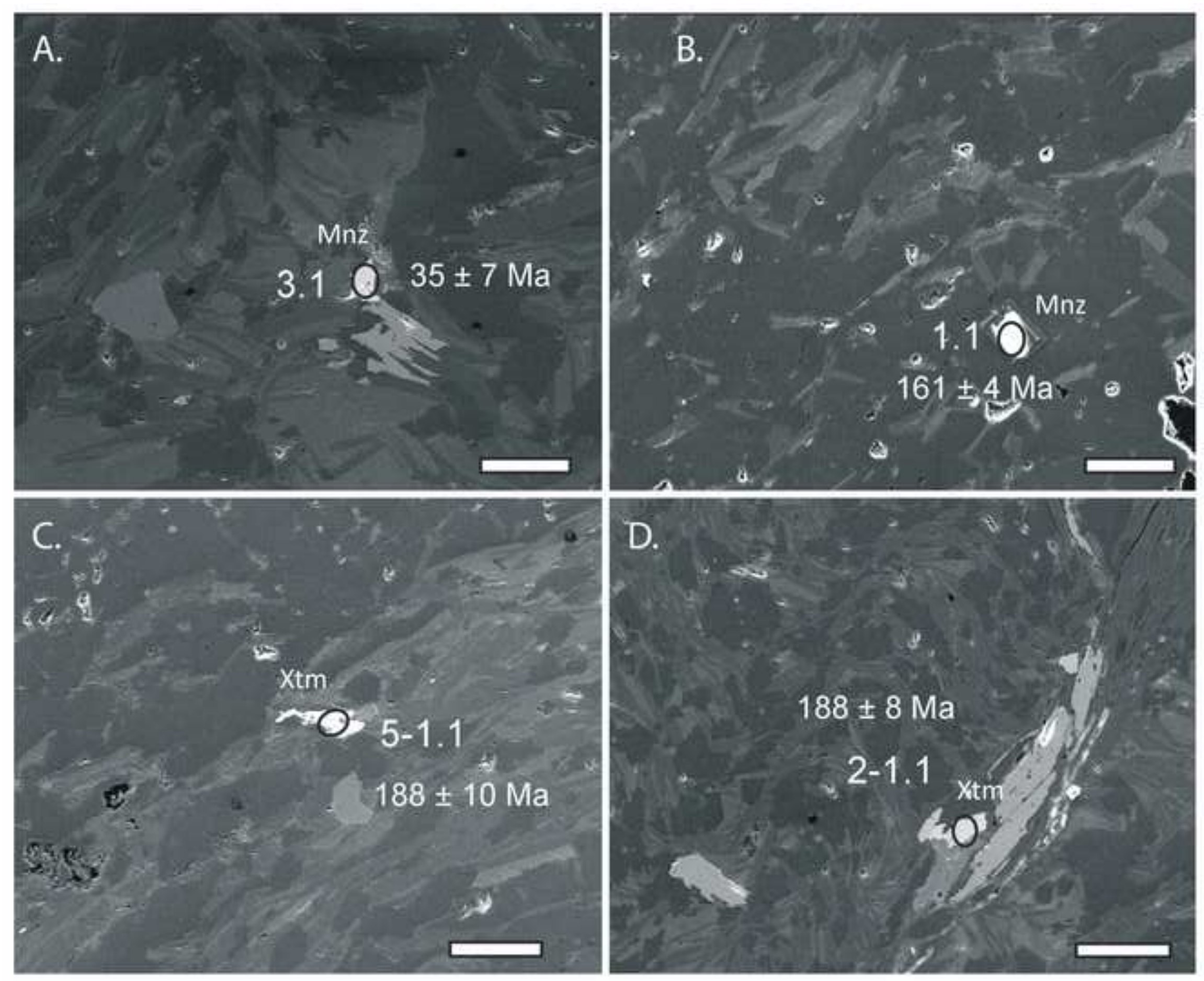


Click here to download high resolution image
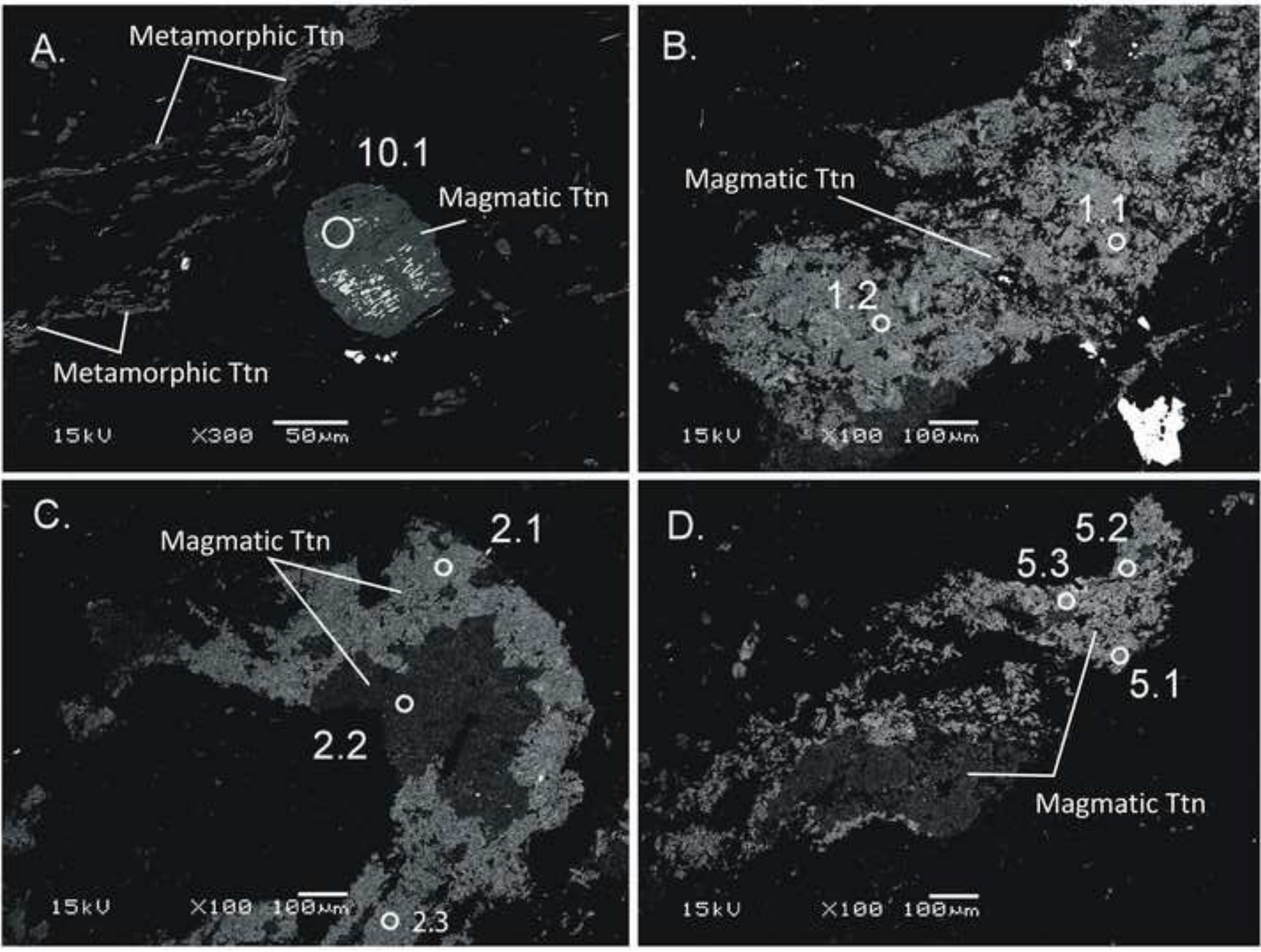

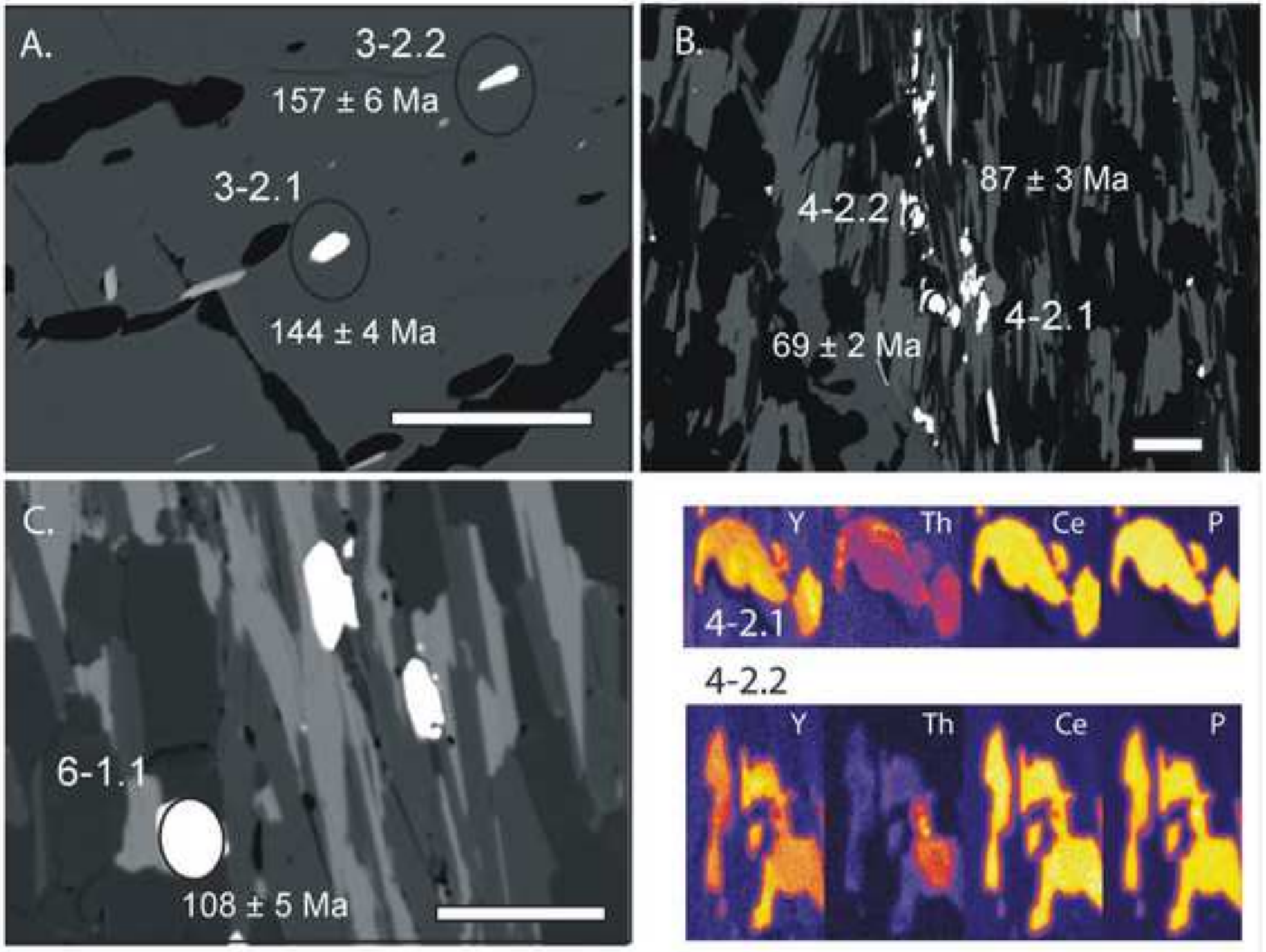

D. $3-2.1$

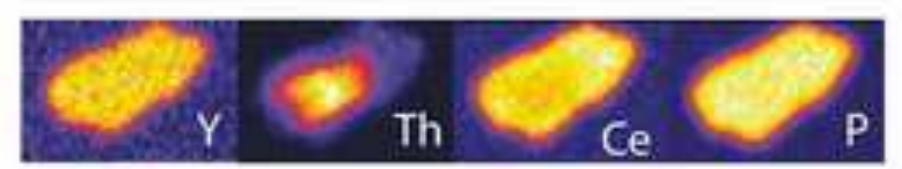

6-1.1

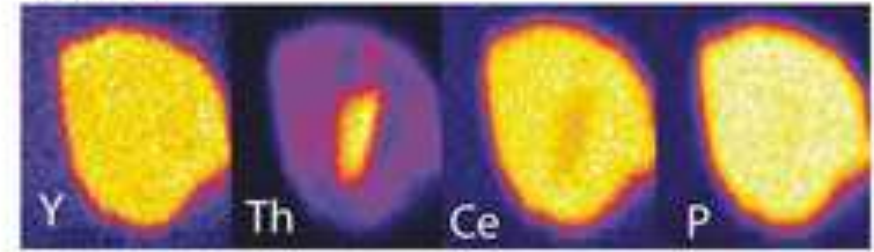




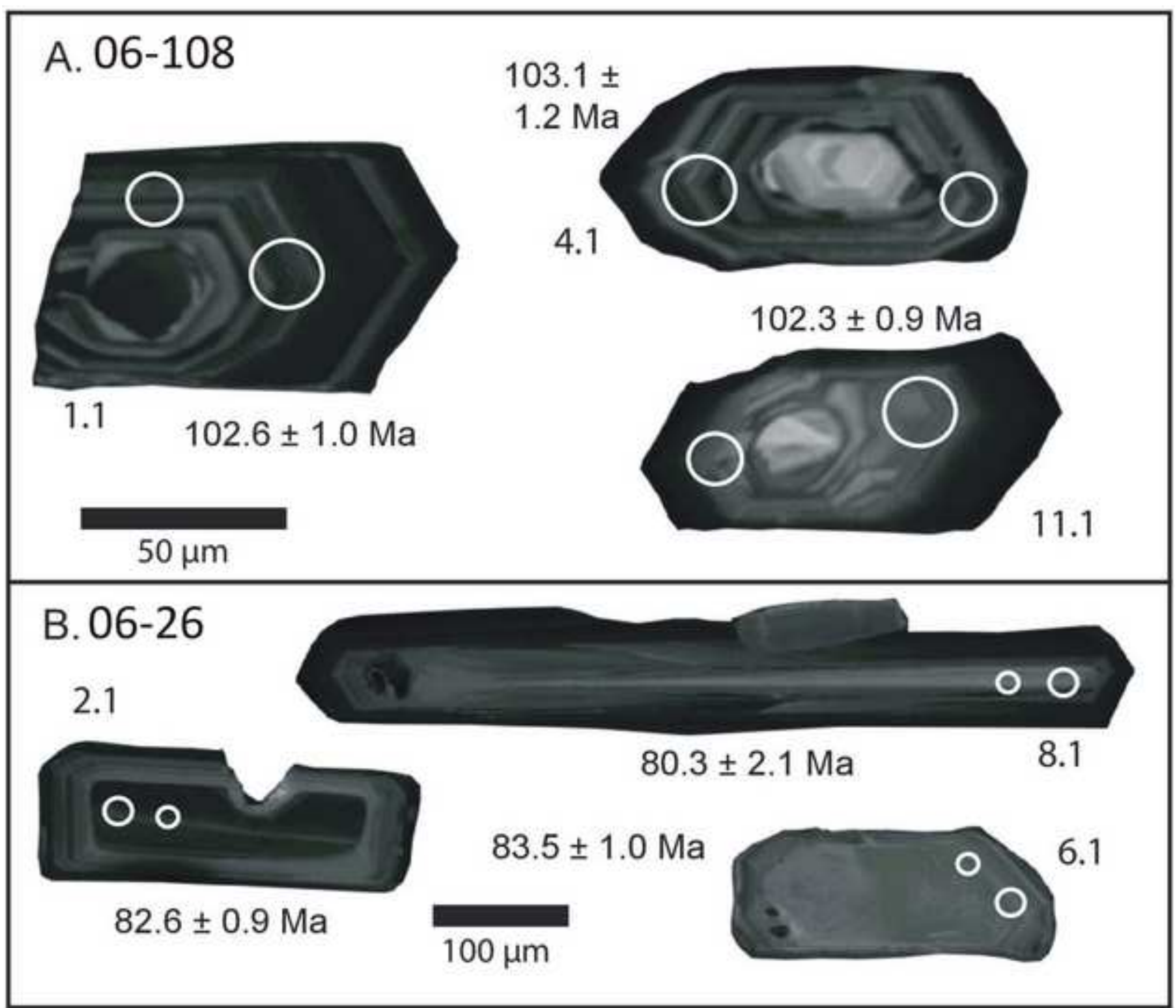

A. $06-108$

$1.2 \mathrm{Ma}$

4.1

$$
80.3 \pm 2.1 \mathrm{Ma}
$$

○ ○

$82.6 \pm 0.9 \mathrm{Ma}$ 


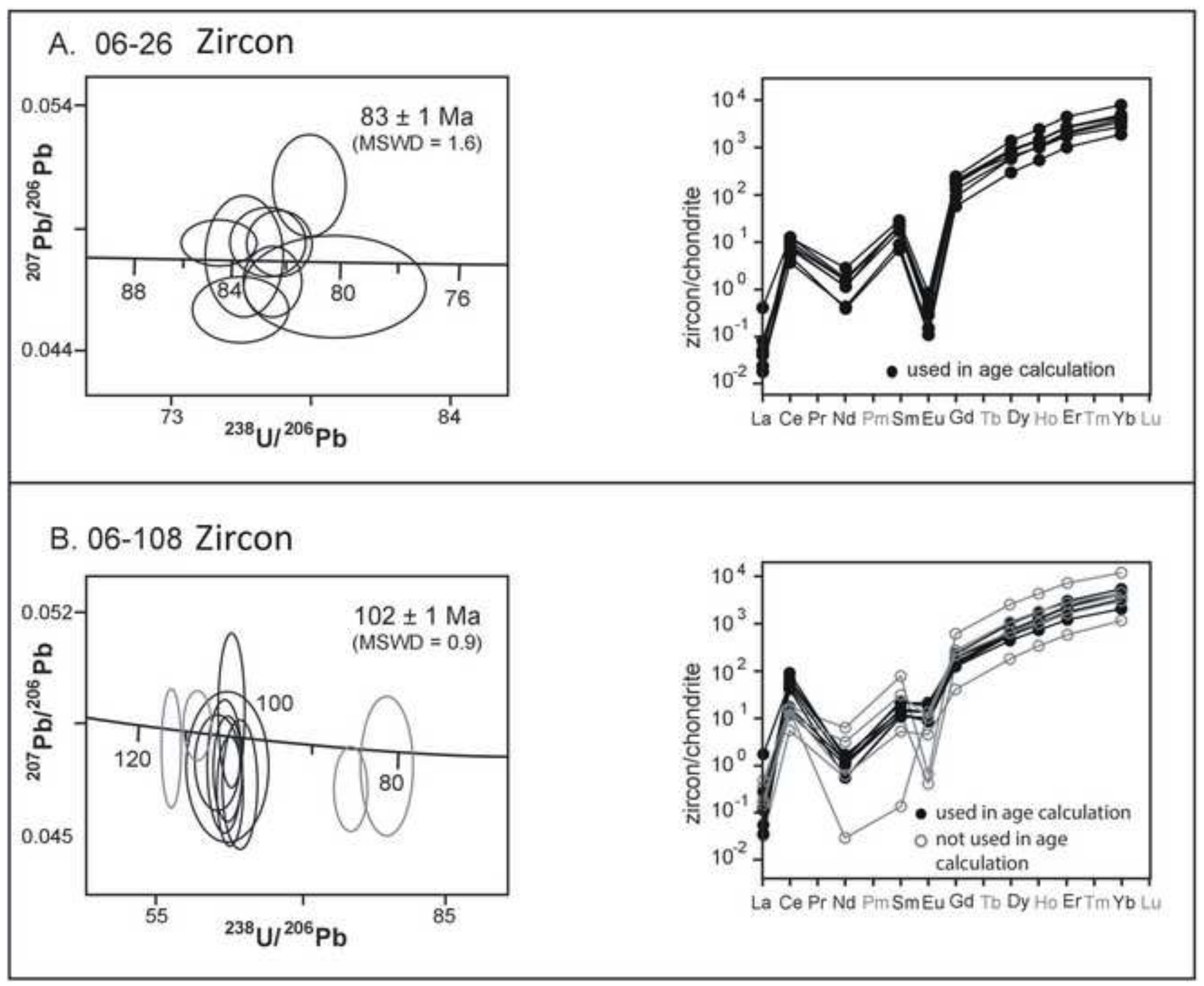


Figure 8

Click here to download high resolution image

\section{A. 06-17 Titanite}

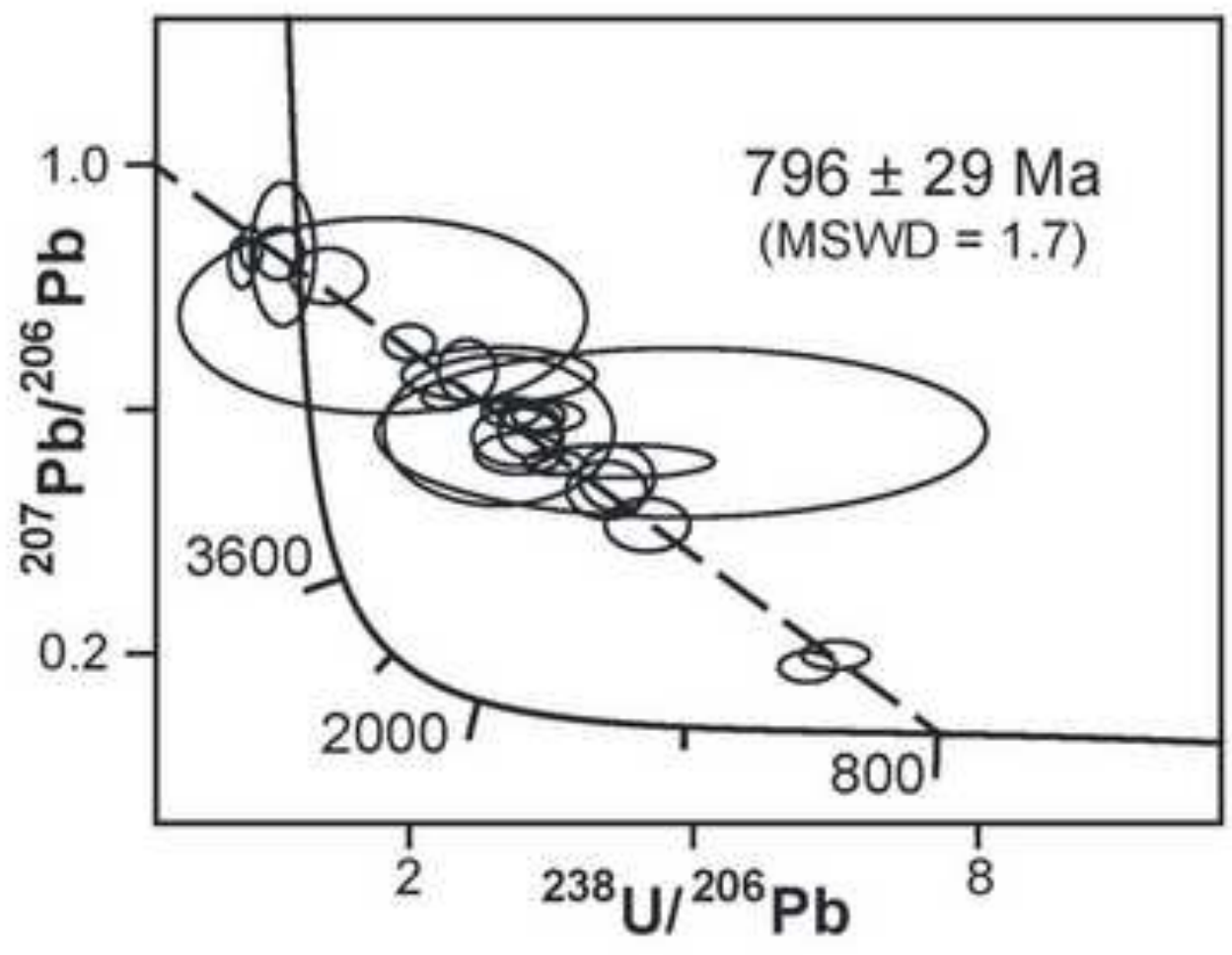

B. 06-10 Titanite

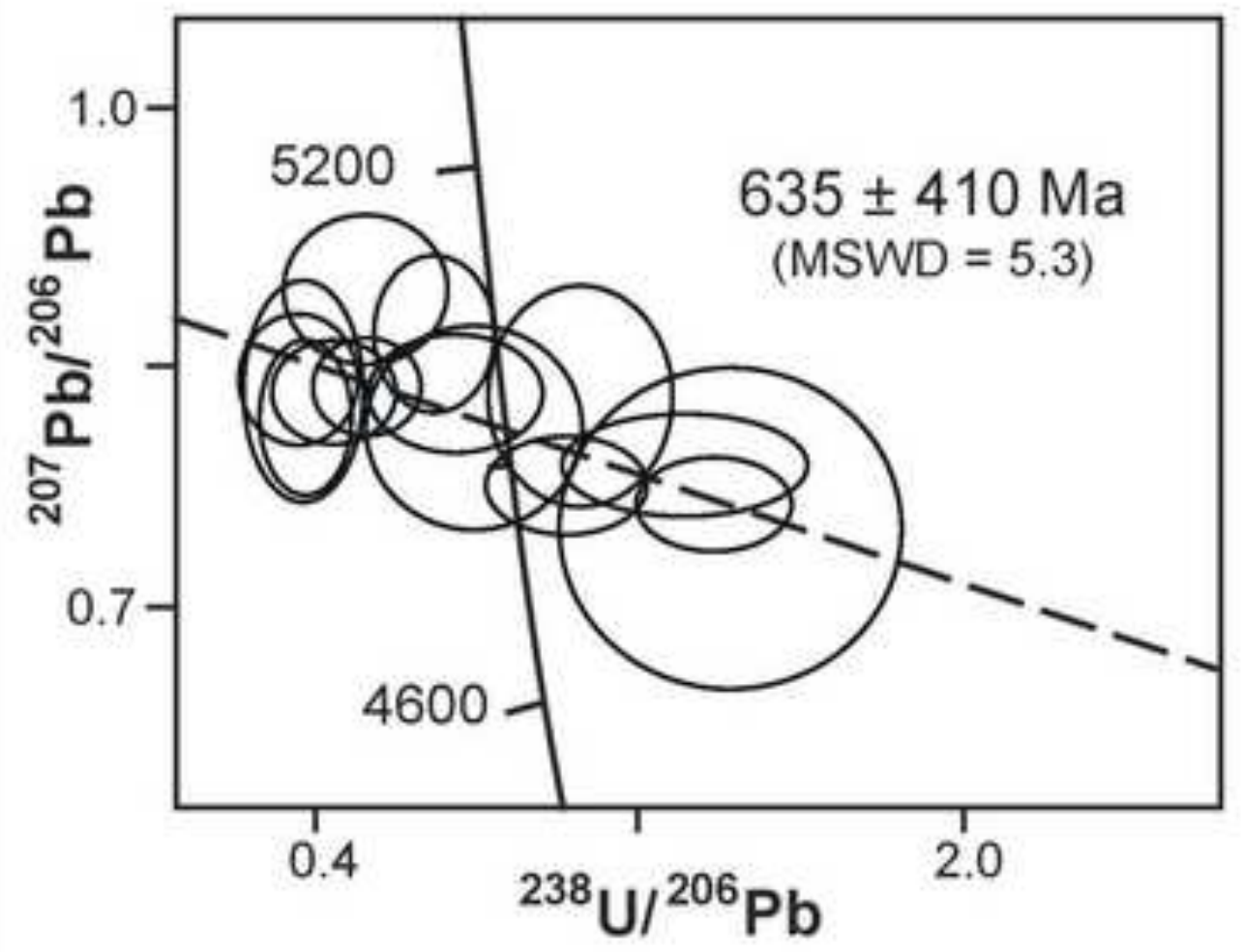


A. 06-01 Xenotime

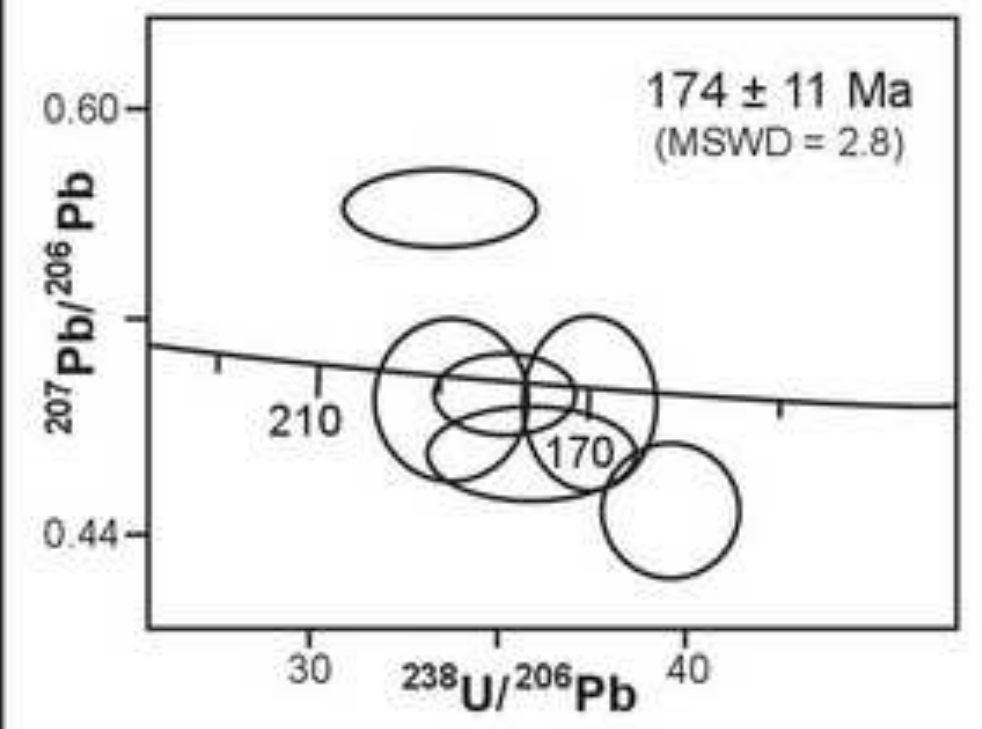

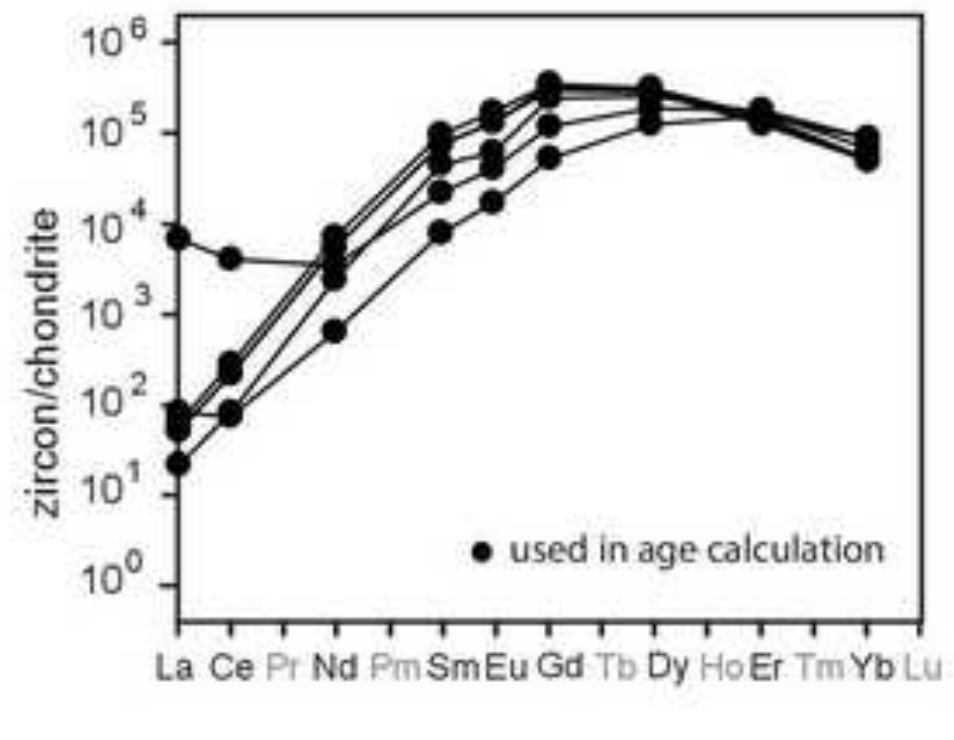

B. 06-115 Monazite

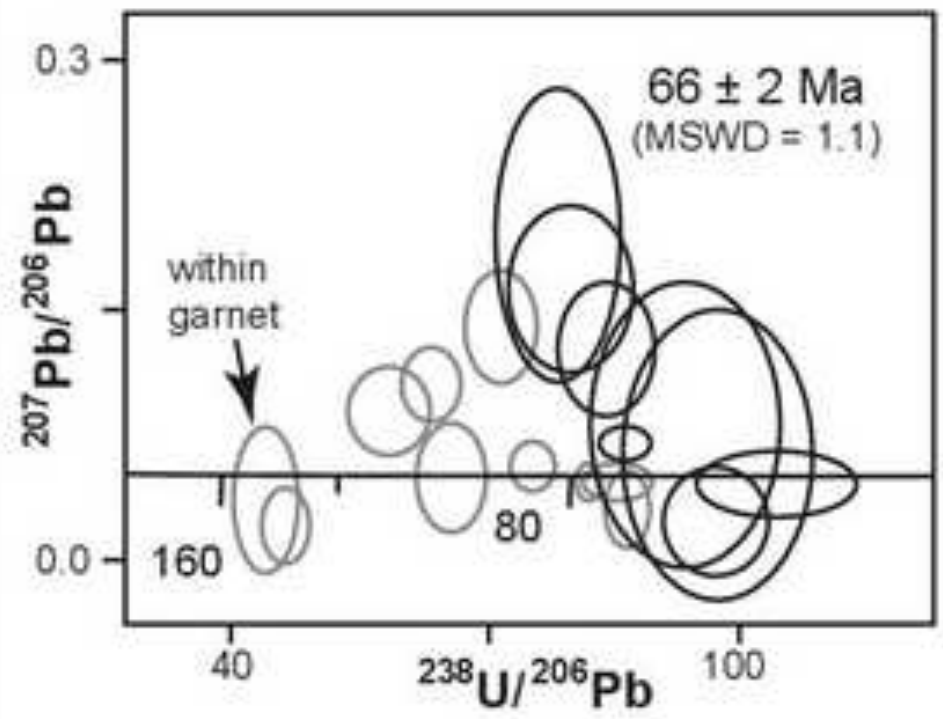

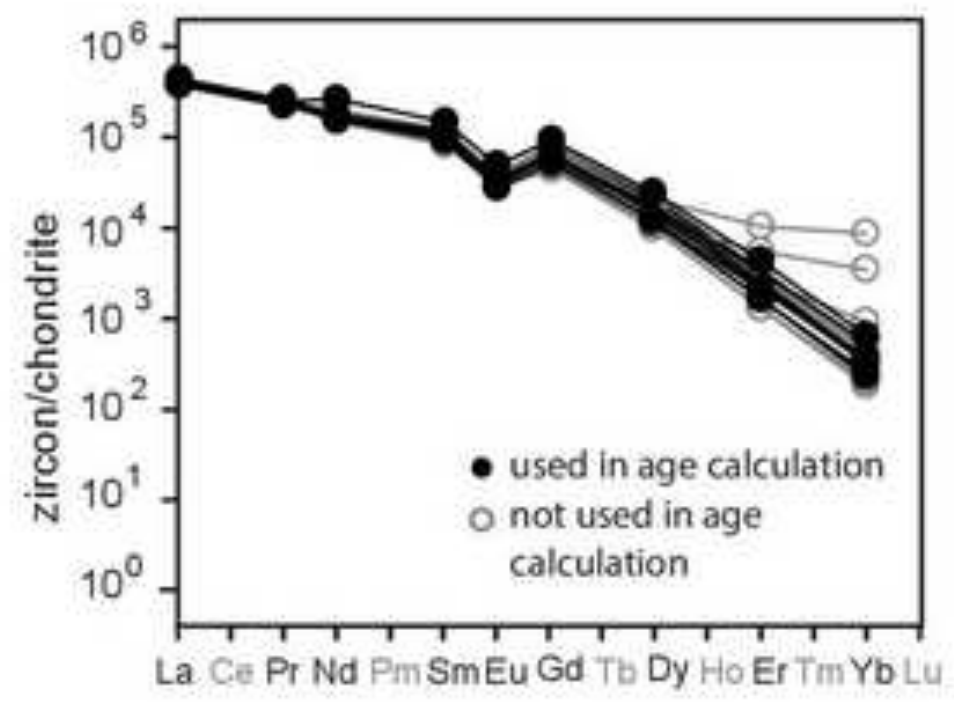


Click here to download high resolution image

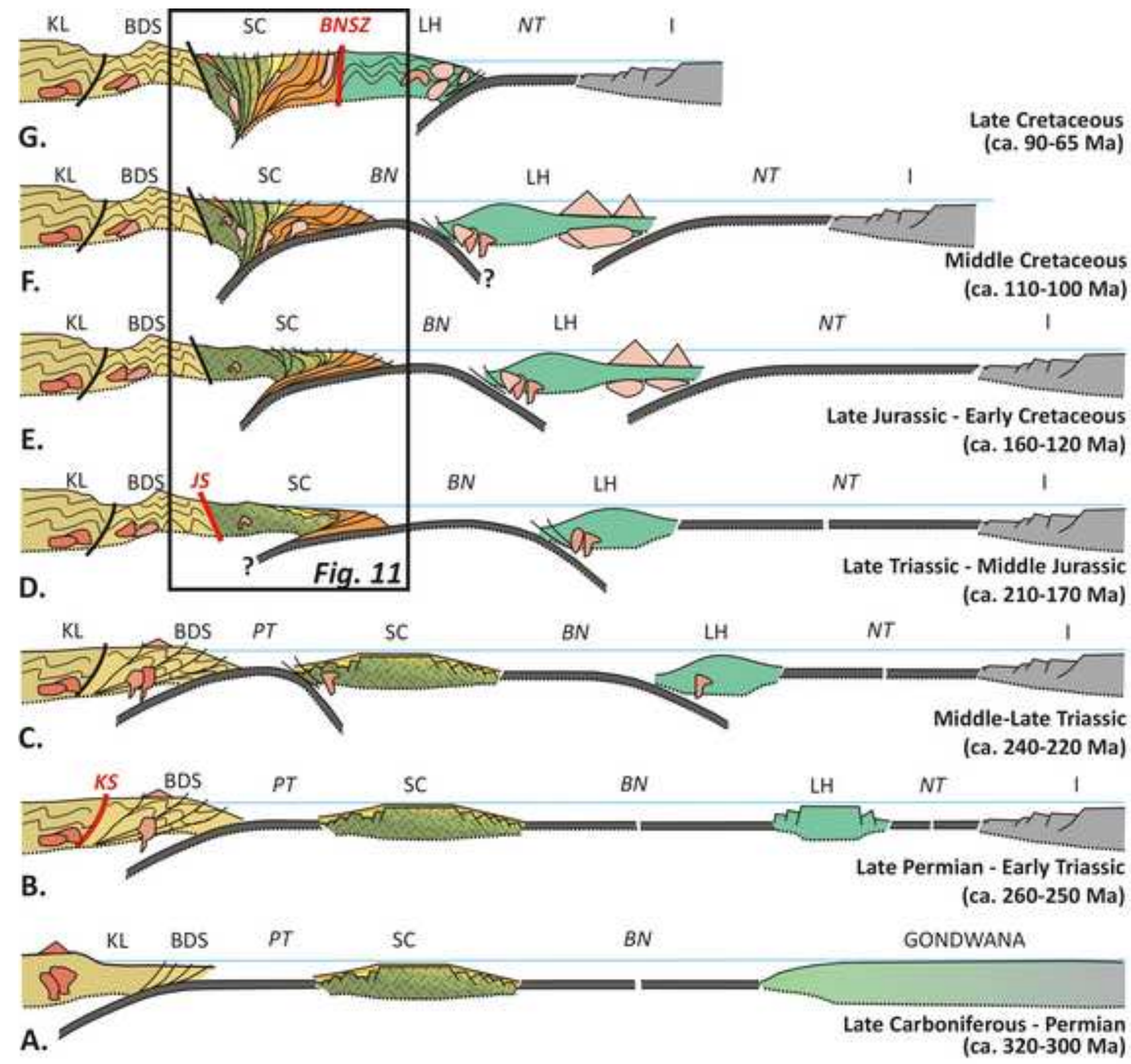

(ca. 320-300 Ma) 


\section{Figure 11}

Click here to download high resolution image

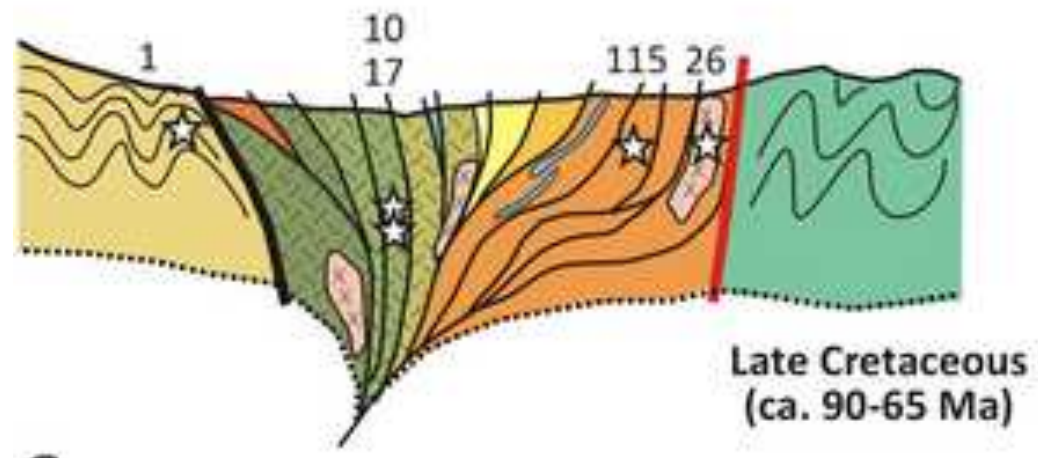

G.
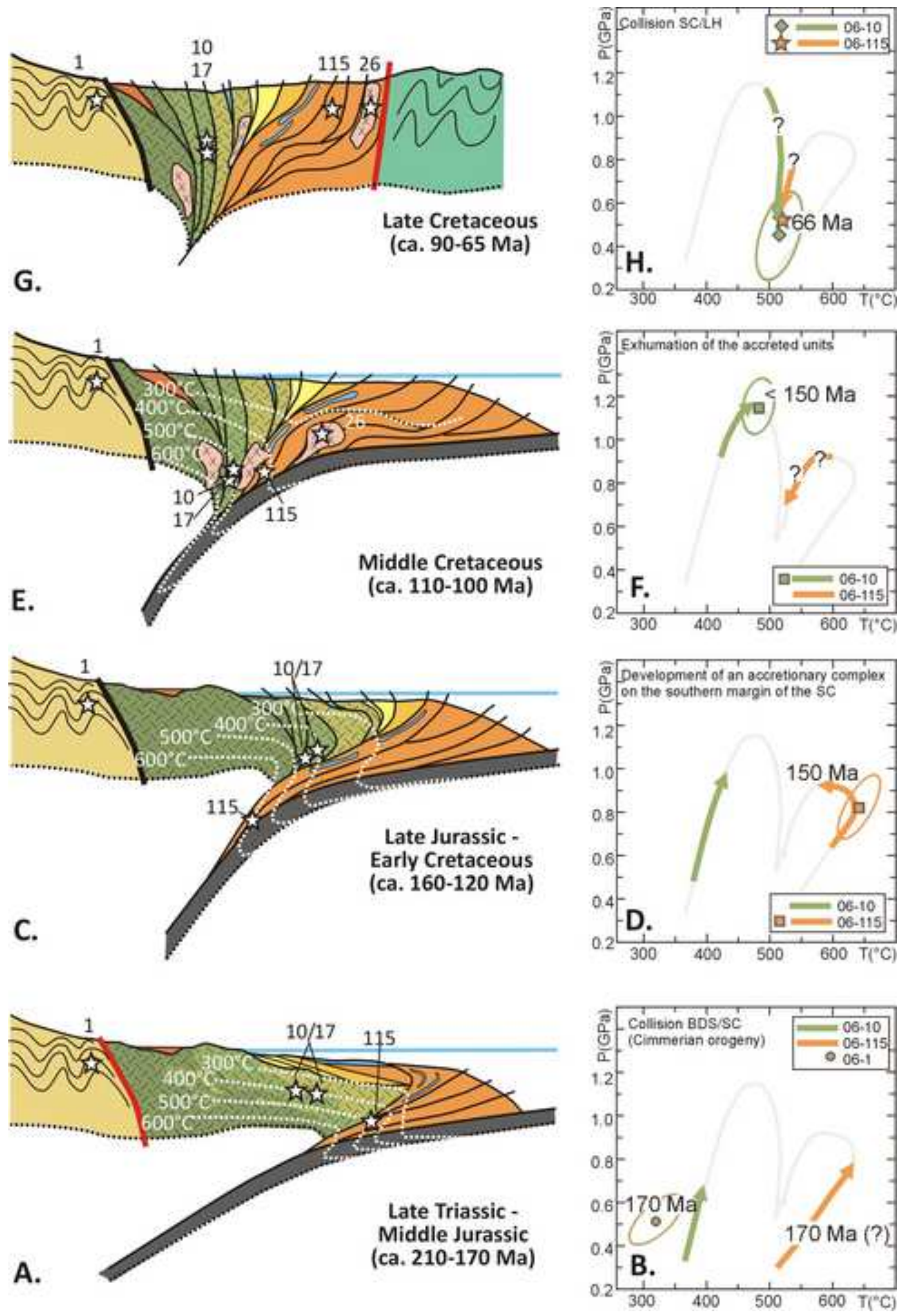

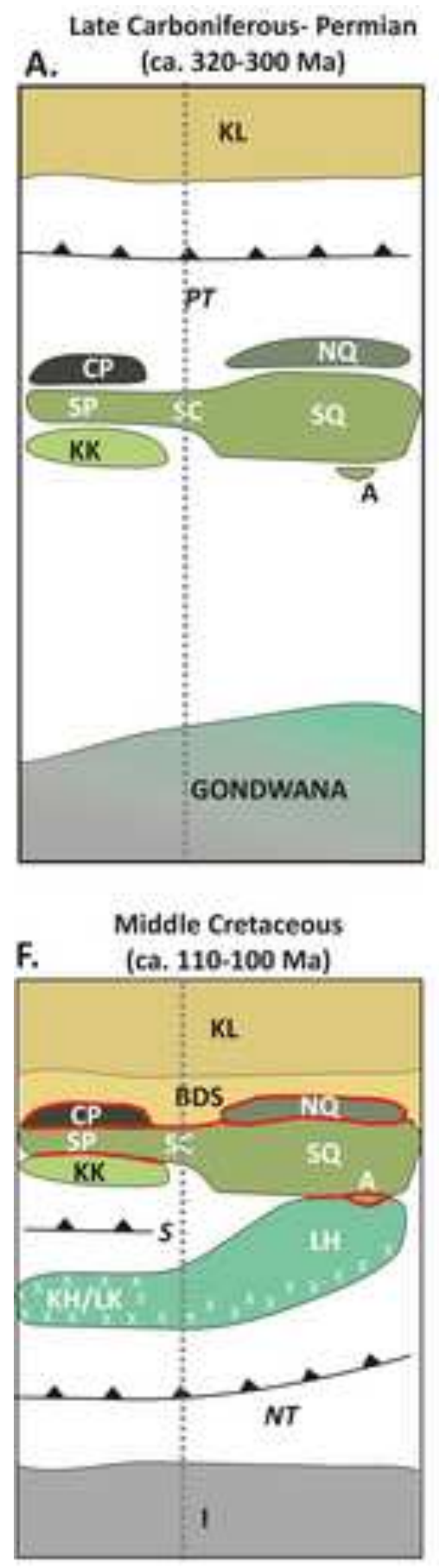

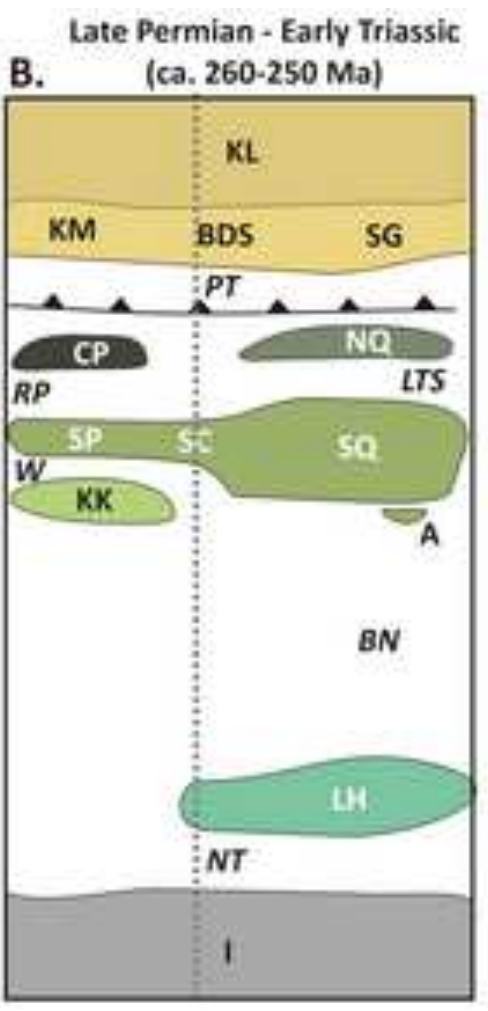

\section{Late Cretaceous}

G.

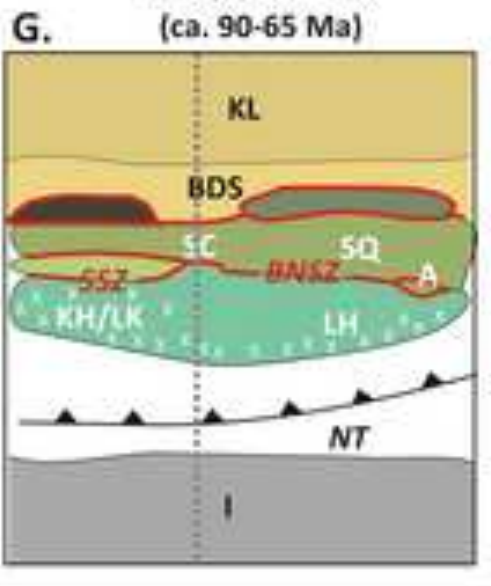

Middle-Late Triassic

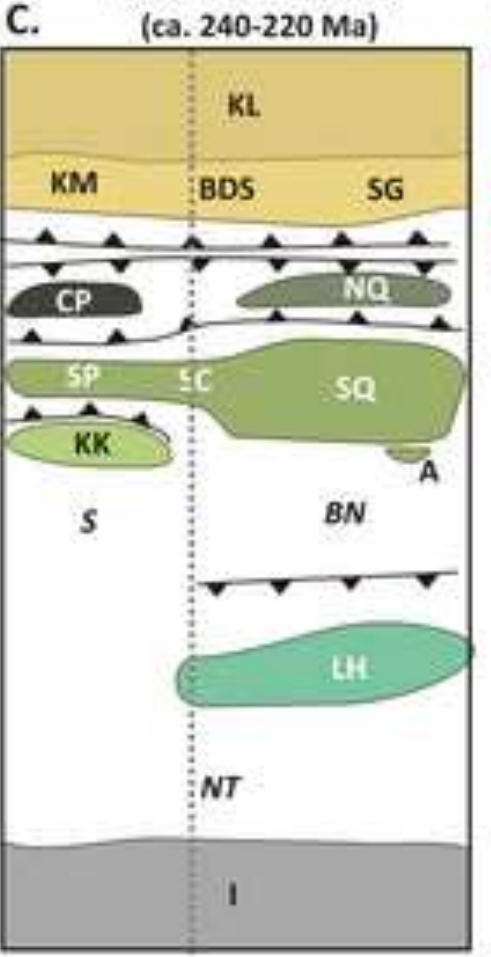

Late Triassic-Middle Jurassic

D. (ca. 210-170 Ma)
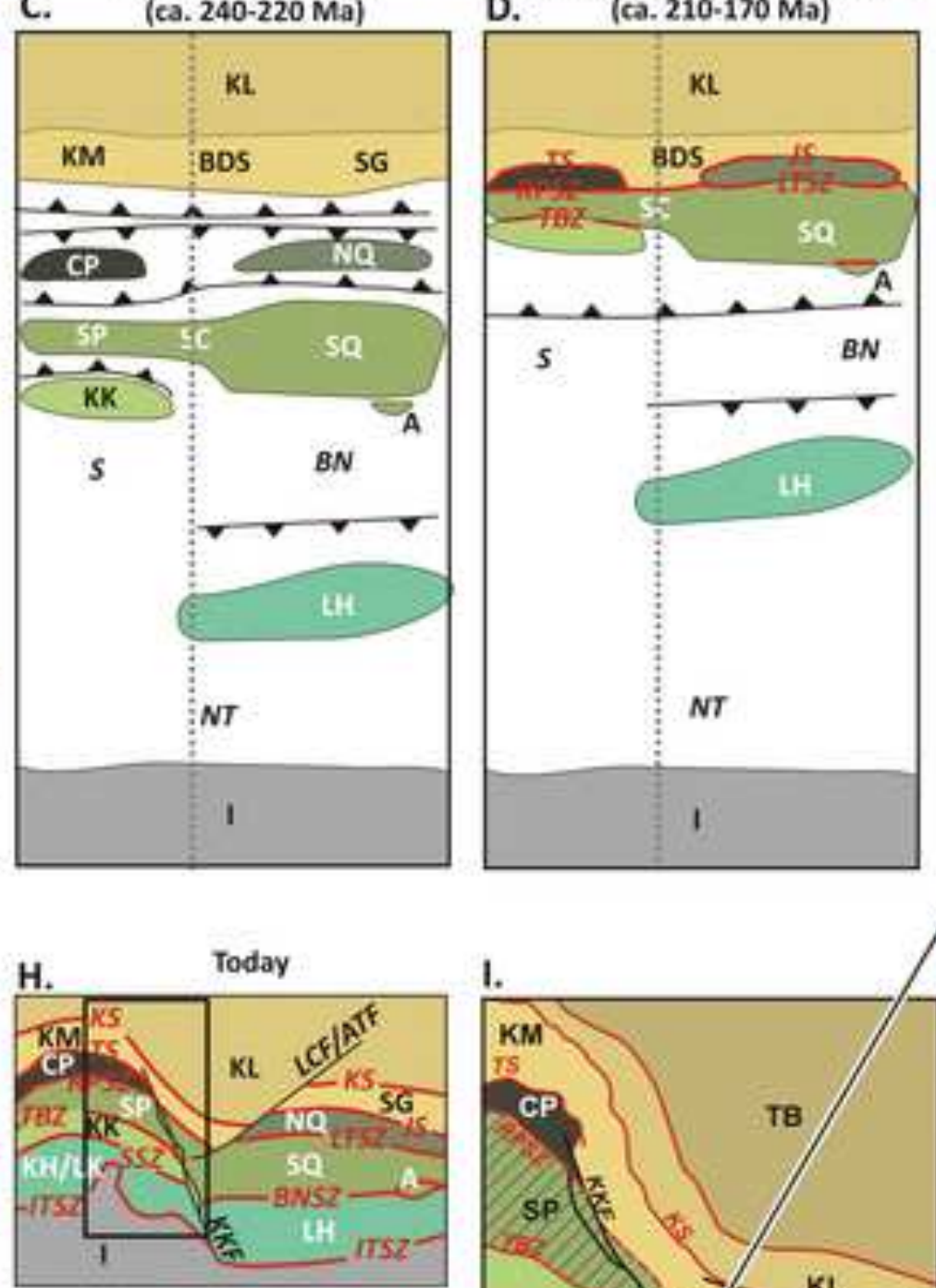

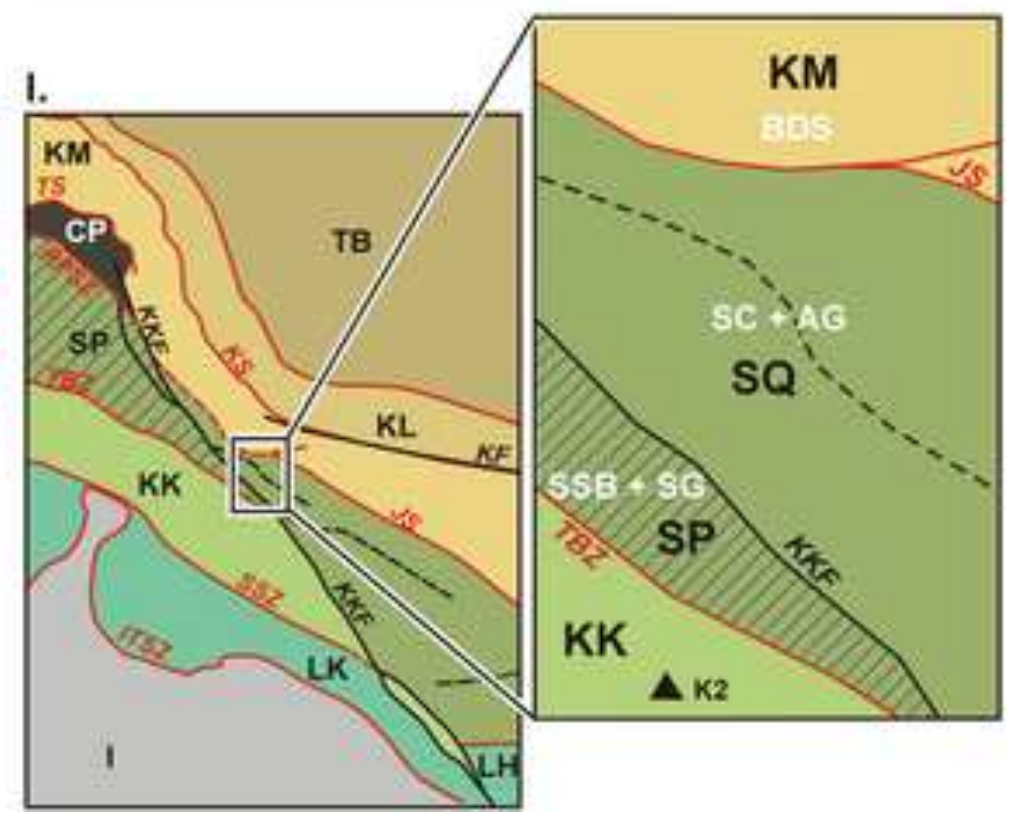

Late Jurassic - Early Cretaceous

E. (ca. 160-120 Ma)

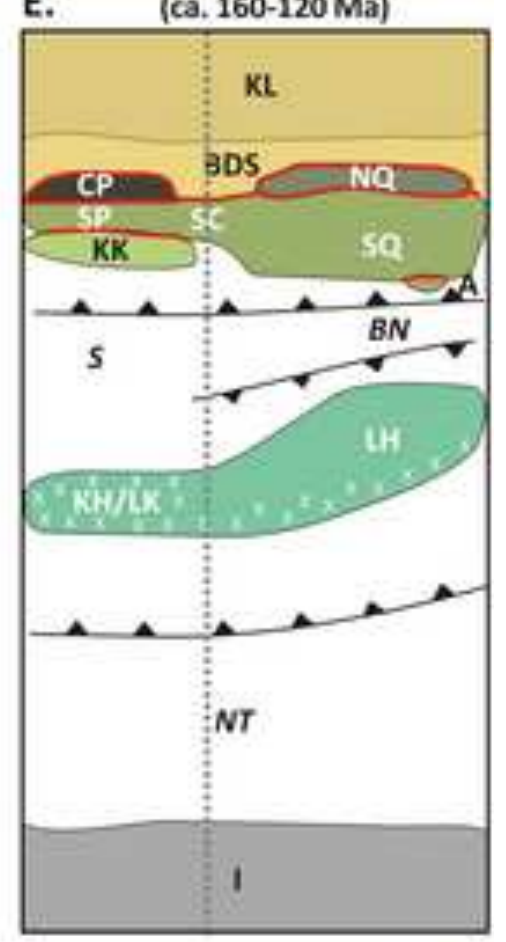


Table 1a.

Representative analyses of minerals in the meta-granodiorite (06-10) and metadiorite (06-17) from the Surukwat Complex.

\begin{tabular}{|c|c|c|c|c|c|c|c|c|c|c|c|c|c|c|c|c|c|c|}
\hline \multirow{3}{*}{$\begin{array}{l}\text { Sample } \\
\text { Assemblage } \\
\text { Analyses }\end{array}$} & \multicolumn{10}{|c|}{$06-10$} & \multicolumn{8}{|c|}{$06-17$} \\
\hline & \multicolumn{5}{|c|}{ Peak-P assemblage } & \multicolumn{5}{|c|}{ Peak-T assemblage } & \multicolumn{4}{|c|}{ Peak-P assemblage } & \multicolumn{4}{|c|}{ Peak-T assemblage } \\
\hline & Act 5.4 & Phe 7.13 & Ep 2.11 & Chl 2.12 & $\mathrm{Ab} 8.4$ & $\mathrm{Hbl} 7.3$ & Mu 4.2 & Ep 4.5 & Chl 7.8 & $A b 7.8$ & Act 7.2 & Chl 1.10 & Ep 1.9 & $A b 7.6$ & $\mathrm{Hbl} 2.3$ & Bi 4.4 & Ep 4.9 & PI 7.5 \\
\hline $\mathrm{SiO}_{2}$ & 53.69 & 49.11 & 37.49 & 27.49 & 68.55 & 49.85 & 47.53 & 38.18 & 28.21 & 67.60 & 52.10 & 29.70 & 38.07 & 68.11 & 42.86 & 36.50 & 37.76 & 67.24 \\
\hline $\mathrm{TiO}_{2}$ & 0.01 & 0.00 & 0.00 & 0.00 & 0.00 & 0.01 & 0.00 & 0.00 & 0.00 & 0.00 & 0.01 & 0.00 & 0.00 & 0.00 & 0.01 & 1.99 & 0.00 & 0.00 \\
\hline $\mathrm{Al}_{2} \mathrm{O}_{3}$ & 2.57 & 26.18 & 23.57 & 20.51 & 19.68 & 6.65 & 27.06 & 23.18 & 20.33 & 19.77 & 2.70 & 17.86 & 22.34 & 19.22 & 9.81 & 15.26 & 22.73 & 19.09 \\
\hline $\mathrm{FeO}$ & 11.88 & 3.76 & 12.37 & 18.44 & 0.00 & 13.69 & 5.36 & 13.47 & 20.51 & 0.00 & 17.25 & 24.84 & 14.10 & 0.00 & 21.24 & 22.53 & 11.88 & 0.00 \\
\hline $\mathrm{MnO}$ & 0.51 & 0.00 & 0.01 & 0.01 & 0.00 & 0.01 & 0.00 & 0.01 & 0.01 & 0.00 & 0.47 & 0.00 & 0.00 & 0.00 & 0.01 & 0.00 & 0.00 & 0.00 \\
\hline $\mathrm{MgO}$ & 17.39 & 3.45 & 0.55 & 20.36 & 0.00 & 14.24 & 3.68 & 0.00 & 19.47 & 0.00 & 12.38 & 12.24 & 1.35 & 0.00 & 7.27 & 9.19 & 0.00 & 0.00 \\
\hline $\mathrm{CaO}$ & 12.37 & 0.00 & 23.34 & 0.00 & 0.32 & 12.38 & 0.00 & 24.30 & 0.00 & 0.36 & 11.93 & 0.00 & 19.92 & 0.25 & 10.94 & 0.00 & 23.49 & 1.03 \\
\hline $\mathrm{Na}_{2} \mathrm{O}$ & 0.01 & 0.01 & 0.00 & 0.00 & 12.31 & 1.00 & 0.29 & 0.00 & 0.00 & 12.21 & 0.05 & 0.00 & 0.00 & 11.16 & 1.36 & 0.00 & 0.00 & 11.14 \\
\hline $\mathrm{K}_{2} \mathrm{O}$ & 0.23 & 10.90 & 0.00 & 0.00 & 0.00 & 0.35 & 10.48 & 0.00 & 0.00 & 0.00 & 0.01 & 0.00 & 0.00 & 0.00 & 0.78 & 9.49 & 0.00 & 0.00 \\
\hline Total & 98.66 & 93.41 & 97.33 & 86.81 & 100.86 & 98.18 & 94.40 & 99.14 & 88.53 & 99.94 & 96.90 & 84.64 & 95.78 & 98.74 & 94.28 & 94.96 & 95.86 & 98.50 \\
\hline $\mathrm{Si}$ & 7.577 & 3.366 & 2.968 & 2.809 & 2.978 & 7.193 & 3.239 & 2.978 & 2.851 & 2.965 & 7.707 & 3.198 & 3.043 & 3.005 & 6.746 & 2.836 & 3.030 & 2.986 \\
\hline $\mathrm{Ti}$ & 0.001 & 0.000 & 0.000 & 0.000 & 0.000 & 0.001 & 0.000 & 0.000 & 0.000 & 0.000 & 0.001 & 0.000 & 0.000 & 0.000 & 0.001 & 0.116 & 0.000 & 0.000 \\
\hline Al & 0.428 & 2.116 & 2.200 & 2.471 & 1.008 & 1.131 & 2.174 & 2.132 & 2.422 & 1.022 & 0.471 & 2.268 & 2.105 & 1.000 & 1.820 & 1.398 & 2.151 & 0.999 \\
\hline $\mathrm{Fe}^{+3}$ & 0.374 & 0.097 & 0.800 & 0.000 & 0.000 & 0.229 & 0.214 & 0.868 & 0.000 & 0.000 & 0.110 & 0.000 & 0.895 & 0.000 & 0.278 & 0.000 & 0.790 & 0.000 \\
\hline $\mathrm{Fe}^{+2}$ & 1.029 & 0.118 & 0.019 & 1.576 & 0.000 & 1.423 & 0.092 & 0.011 & 1.733 & 0.000 & 2.024 & 2.237 & 0.048 & 0.000 & 2.520 & 1.464 & 0.008 & 0.000 \\
\hline $\mathrm{Mn}$ & 0.061 & 0.000 & 0.001 & 0.001 & 0.000 & 0.001 & 0.000 & 0.001 & 0.001 & 0.000 & 0.059 & 0.000 & 0.000 & 0.000 & 0.001 & 0.000 & 0.000 & 0.000 \\
\hline $\mathrm{Mg}$ & 3.658 & 0.352 & 0.065 & 3.100 & 0.000 & 3.062 & 0.374 & 0.000 & 2.932 & 0.000 & 2.729 & 1.964 & 0.161 & 0.000 & 1.705 & 1.064 & 0.000 & 0.000 \\
\hline $\mathrm{Ca}$ & 1.871 & 0.000 & 1.980 & 0.000 & 0.015 & 1.914 & 0.000 & 2.031 & 0.000 & 0.017 & 1.891 & 0.000 & 1.706 & 0.012 & 1.845 & 0.000 & 2.020 & 0.049 \\
\hline $\mathrm{Na}$ & 0.003 & 0.001 & 0.000 & 0.000 & 1.037 & 0.280 & 0.038 & 0.000 & 0.000 & 1.038 & 0.014 & 0.000 & 0.000 & 0.955 & 0.415 & 0.000 & 0.000 & 0.959 \\
\hline $\mathrm{K}$ & 0.041 & 0.953 & 0.000 & 0.000 & 0.000 & 0.064 & 0.911 & 0.000 & 0.000 & 0.000 & 0.002 & 0.000 & 0.000 & 0.000 & 0.157 & 0.941 & 0.000 & 0.000 \\
\hline $\mathrm{XMg}\left(\mathrm{Fe}_{\mathrm{tot}}\right)$ & 0.72 & & & 0.66 & & 0.65 & & & 0.63 & & 0.56 & 0.47 & & & 0.38 & 0.42 & & \\
\hline XAb & & & & & 0.99 & & & & & 0.98 & & & & 0.99 & & & & 0.95 \\
\hline XPs & & & 0.27 & & & & & 0.29 & & & & & 0.30 & & & & 0.27 & \\
\hline
\end{tabular}


Table 1b.

Representative analyses of minerals in the metapelites from the Bazar Dara Slates (06-1) and Surukwat Complex (06-115).

\begin{tabular}{|c|c|c|c|c|c|c|c|c|}
\hline \multirow{3}{*}{$\begin{array}{l}\text { Sample } \\
\text { Assemblage } \\
\text { Analyses }\end{array}$} & \multicolumn{4}{|c|}{$06-1$} & \multicolumn{4}{|c|}{$06-115$} \\
\hline & \multirow[b]{2}{*}{ Bt 1.9} & \multirow[b]{2}{*}{ Mu 1.16} & \multirow[b]{2}{*}{ Chl 1.14} & \multirow[b]{2}{*}{$\mathrm{Ab} 1.23$} & \multicolumn{4}{|c|}{ Peak-P assemblage } \\
\hline & & & & & Bt 2.2 & Mu 8.10 & Grt 5.11 & $\mathrm{PI} 3.6$ \\
\hline $\mathrm{SiO}_{2}$ & 36.03 & 47.99 & 29.02 & 67.15 & 35.37 & 46.37 & 36.10 & 66.01 \\
\hline $\mathrm{TiO}_{2}$ & 1.97 & 0.60 & 0.00 & 0.00 & 1.85 & 0.42 & 0.00 & 0.00 \\
\hline $\mathrm{Al}_{2} \mathrm{O}_{3}$ & 16.13 & 29.10 & 20.32 & 19.79 & 18.13 & 35.01 & 20.14 & 20.75 \\
\hline $\mathrm{FeO}$ & 19.73 & 3.07 & 22.59 & 0.00 & 21.22 & 1.28 & 33.28 & 0.00 \\
\hline $\mathrm{MnO}$ & 0.00 & 0.00 & 0.00 & 0.00 & 0.00 & 0.00 & 6.38 & 0.00 \\
\hline $\mathrm{MgO}$ & 12.02 & 2.46 & 15.09 & 0.00 & 9.02 & 0.47 & 2.28 & 0.00 \\
\hline $\mathrm{CaO}$ & 0.00 & 0.00 & 0.00 & 0.32 & 0.00 & 0.00 & 0.96 & 1.56 \\
\hline $\mathrm{Na}_{2} \mathrm{O}$ & 0.00 & 0.45 & 0.00 & 12.24 & 0.00 & 1.23 & 0.00 & 11.66 \\
\hline $\mathrm{K}_{2} \mathrm{O}$ & 6.91 & 10.48 & 0.00 & 0.00 & 9.25 & 9.06 & 0.00 & 0.00 \\
\hline Total & 92.79 & 94.15 & 87.02 & 99.50 & 94.84 & 93.84 & 99.14 & 99.98 \\
\hline Si & 2.760 & 3.263 & 3.002 & 2.960 & 2.727 & 3.110 & 2.962 & 2.906 \\
\hline $\mathrm{Ti}$ & 0.113 & 0.031 & 0.000 & 0.000 & 0.107 & 0.021 & 0.000 & 0.000 \\
\hline $\mathrm{Fe}^{+3}$ & 0.190 & 0.012 & 0.000 & 0.000 & 0.000 & 0.000 & 0.128 & 0.000 \\
\hline $\mathrm{Fe}^{+2}$ & 1.074 & 0.163 & 1.954 & 0.000 & 1.368 & 0.072 & 2.155 & 0.000 \\
\hline $\mathrm{Mn}$ & 0.000 & 0.000 & 0.000 & 0.000 & 0.000 & 0.000 & 0.443 & 0.000 \\
\hline $\mathrm{Mg}$ & 1.372 & 0.249 & 2.326 & 0.000 & 1.036 & 0.047 & 0.279 & 0.000 \\
\hline $\mathrm{Ca}$ & 0.000 & 0.000 & 0.000 & 0.015 & 0.000 & 0.000 & 0.084 & 0.074 \\
\hline $\mathrm{Na}$ & 0.000 & 0.059 & 0.000 & 1.046 & 0.000 & 0.160 & 0.000 & 0.995 \\
\hline K & 0.675 & 0.909 & 0.000 & 0.000 & 0.910 & 0.775 & 0.000 & 0.000 \\
\hline $\mathrm{XMg}\left(\mathrm{Fe}_{\text {tot }}\right)$ & 0.52 & & 0.54 & & 0.43 & & & \\
\hline$X A b$ & & & & 0.99 & & & & 0.93 \\
\hline
\end{tabular}


Table 2

Average pressure-temperatures estimates for the studied samples.

\begin{tabular}{|c|c|c|c|c|c|c|}
\hline Unit & Sample & Assemblage & $\mathrm{T}\left({ }^{\circ} \mathrm{C}\right)$ & P (kbar) & $\sigma$ fit & $\begin{array}{c}\mathbf{N}^{\circ} \text { of } \\
\text { reactions }\end{array}$ \\
\hline Bazar Dara Slates & $06-1$ & Bt-Mu-Chl-PI-Qz- $\mathrm{H}_{2} \mathrm{O}$ & $320 \pm 32$ & $5.2 \pm 0.9$ & 0.99 & 4 \\
\hline Surukwat Complex & 06-10 (peak-P) & Act-Ab-Phe-Chl-Ep-Qz-Ttn-Ru- $\mathrm{H}_{2} \mathrm{O}$ & $482 \pm 20$ & $11.5 \pm 1.2$ & 1.10 & 5 \\
\hline Surukwat Complex & 06-10 (peak-T) & $\mathrm{Hbl}-\mathrm{Ab}-\mathrm{Mu}$-Chl-Ep-Qz-Ttn-Ru- $\mathrm{H}_{2} \mathrm{O}$ & $512 \pm 30$ & $4.5 \pm 1.7$ & 1.33 & 6 \\
\hline Surukwat Complex & 06-115 & Grt-Mu-Bt-PI-Qz-IIm- $\mathrm{H}_{2} \mathrm{O}$ & $645 \pm 26$ & $8.2 \pm 1.2$ & 0.71 & 6 \\
\hline
\end{tabular}


Table 3

SIMS U-Pb geochronologic zircon data and apparent ages.

\begin{tabular}{|c|c|c|c|c|c|c|c|c|c|c|c|}
\hline Spot $^{a}$ & $\begin{array}{c}\mathrm{U} \\
(\mathrm{ppm}) \\
\end{array}$ & $\begin{array}{c}\text { Th } \\
(\mathrm{ppm})\end{array}$ & $\mathrm{Th} / \mathrm{U}$ & $\begin{array}{l}{ }^{206} \mathrm{~Pb}^{* b} \\
(\mathrm{ppm})\end{array}$ & $f^{206} \mathrm{~Pb}_{\mathrm{c}}{ }^{\mathrm{b}}$ & ${ }^{238} \mathrm{U} /{ }^{206} \mathrm{~Pb}^{\mathrm{c}}$ & $\begin{array}{l}1 \sigma \\
(\%)\end{array}$ & ${ }^{207} \mathrm{~Pb} /{ }^{206} \mathrm{~Pb}^{\mathrm{c}}$ & $\begin{array}{l}1 \sigma \\
(\%)\end{array}$ & $\begin{array}{c}{ }^{206} \mathrm{~Pb} /{ }^{238} \mathrm{U}^{\mathrm{d}} \\
(\mathrm{Ma})\end{array}$ & $\begin{array}{l}1 \sigma \\
(\%)\end{array}$ \\
\hline \multicolumn{12}{|c|}{ Sample 06-108 } \\
\hline 10.1 & 1208 & 215 & 0.18 & 11 & $<0.01$ & 78.911 & 1.4 & 0.04719 & 1.9 & 81.2 & 1.1 \\
\hline 3.1 & 3679 & 910 & 0.25 & 37 & $<0.01$ & 75.140 & 1.0 & 0.04641 & 1.1 & 85.4 & 0.8 \\
\hline 12.1 & 1179 & 374 & 0.32 & 14 & $<0.01$ & 63.743 & 1.0 & 0.04662 & 1.8 & 101 & 1.0 \\
\hline 5.1 & 1001 & 348 & 0.35 & 12 & 0.11 & 62.778 & 0.8 & 0.04894 & 2.0 & 102 & 0.8 \\
\hline 11.1 & 1550 & 398 & 0.26 & 19 & $<0.01$ & 62.638 & 0.8 & 0.04641 & 1.5 & 102 & 0.9 \\
\hline 1.1 & 1901 & 621 & 0.33 & 23 & $<0.01$ & 62.407 & 1.0 & 0.04710 & 1.5 & 103 & 1.0 \\
\hline 7.1 & 922 & 174 & 0.19 & 11 & $<0.01$ & 62.284 & 2.8 & 0.04718 & 2.0 & 103 & 2.9 \\
\hline 4.1 & 1286 & 468 & 0.36 & 16 & $<0.01$ & 62.124 & 1.2 & 0.04717 & 1.8 & 103 & 1.2 \\
\hline 6.1 & 2106 & 267 & 0.13 & 26 & $<0.01$ & 61.323 & 1.6 & 0.04729 & 1.3 & 104 & 1.6 \\
\hline 9.1 & 3976 & 430 & 0.11 & 50 & 0.03 & 59.251 & 1.0 & 0.04845 & 0.9 & 108 & 1.1 \\
\hline 8.1 & 1403 & 306 & 0.22 & 19 & $<0.01$ & 56.574 & 0.8 & 0.04772 & 1.6 & 113 & 0.9 \\
\hline 2.1 & 223 & 68 & 0.31 & 52 & 2.46 & 3.134 & 1.7 & 0.12830 & 1.4 & 1747 & 30 \\
\hline \multicolumn{12}{|c|}{ Sample 06-26 } \\
\hline 6.1 & 514 & 291 & 0.57 & 5 & $<0.01$ & 79.892 & 2.7 & 0.04660 & 3.0 & 80.3 & 2.1 \\
\hline 4.1 & 782 & 109 & 0.14 & 7 & 0.39 & 78.969 & 1.1 & 0.05072 & 2.7 & 80.8 & 0.9 \\
\hline 3.1 & 1355 & 281 & 0.21 & 13 & 0.09 & 77.912 & 1.0 & 0.04838 & 1.8 & 82.1 & 0.8 \\
\hline 5.1 & 1182 & 216 & 0.18 & 11 & $<0.01$ & 77.658 & 0.9 & 0.04682 & 2.0 & 82.6 & 0.7 \\
\hline 2.1 & 1323 & 324 & 0.24 & 13 & 0.09 & 77.470 & 1.1 & 0.04844 & 1.9 & 82.6 & 0.9 \\
\hline 8.1 & 1320 & 296 & 0.22 & 13 & 0.02 & 76.660 & 1.2 & 0.04784 & 3.5 & 83.5 & 1.0 \\
\hline 7.1 & 1138 & 124 & 0.11 & 11 & $<0.01$ & 76.540 & 1.5 & 0.04571 & 2.0 & 83.9 & 1.2 \\
\hline 1.1 & 2451 & 363 & 0.15 & 24 & 0.09 & 75.744 & 1.2 & 0.04842 & 1.3 & 84.5 & 1.0 \\
\hline
\end{tabular}

${ }^{a}$ Label format is grain number.spot number

${ }^{\mathrm{b}} \mathrm{Pb} *$ denotes radiogenic $\mathrm{Pb} ; \mathrm{Pb}_{\mathrm{c}}$ denotes common $\mathrm{Pb} ; \mathrm{f}^{206} \mathrm{~Pb}_{\mathrm{c}}=100 *\left({ }^{206} \mathrm{~Pb}_{\mathrm{c}}{ }^{206} \mathrm{~Pb}_{\text {total }}\right)$

${ }^{c}$ Calibration concentrations and isotopic compositions were based on replicate analyses of R33 (419 Ma, Black et al., 2004) and Madagascar Green (MADDER; 3435 ppm U, Barth \& Wooden, 2010). Reported ratios are not corrected for common Pb. Errors are reported as percent at the $1 \sigma$ level.

${ }^{\mathrm{d}}$ Ages were calculated from ${ }^{206} \mathrm{~Pb} /{ }^{238} \mathrm{U}$ ratios corrected for common $\mathrm{Pb}$ using the ${ }^{207} \mathrm{~Pb}$ method and ${ }^{207} \mathrm{~Pb} /{ }^{206} \mathrm{~Pb}$ ratios corrected for common $\mathrm{Pb}$ using the ${ }^{204} \mathrm{~Pb}$ method $($ see Williams, 1998). Initial common $\mathrm{Pb}$ isotopic composition approximated from Stacey \& Kramers (1975). Uncertainties in millions of years reported as $1 \sigma$. Apparent ages in bold are used in age calculations discussed in the text. 
Table 4

SIMS U-Pb geochronologic titanite data and apparent ages.

\begin{tabular}{|c|c|c|c|c|c|c|c|c|c|c|c|c|c|c|c|}
\hline Spot $^{\mathrm{a}}$ & ${ }^{206} \mathrm{~Pb} /{ }^{204} \mathrm{~Pb}$ & $\begin{array}{l}1 \sigma \\
(\%) \\
\end{array}$ & $\begin{array}{c}U \\
(\mathrm{ppm})\end{array}$ & $\begin{array}{c}\text { Th } \\
(\mathrm{ppm})\end{array}$ & Th/U & $\begin{array}{c}{ }^{206} \mathrm{~Pb}^{* b} \\
(\mathrm{ppm})\end{array}$ & $\mathrm{f}^{206} \mathrm{~Pb}_{\mathrm{c}}^{\mathrm{b}}$ & ${ }^{238} \mathrm{U}^{206} \mathrm{~Pb}^{\mathrm{c}}$ & $\begin{array}{l}1 \sigma \\
(\%) \\
\end{array}$ & ${ }^{207} \mathrm{~Pb} /{ }^{206} \mathrm{~Pb}^{\mathrm{c}}$ & $\begin{array}{l}1 \sigma \\
(\%) \\
\end{array}$ & $\begin{array}{c}{ }^{206} \mathrm{~Pb} /{ }^{238} \mathrm{U}^{\mathrm{d}} \\
(\mathrm{Ma})\end{array}$ & $\begin{array}{l}1 \sigma \\
(\%) \\
\end{array}$ & $\begin{array}{c}{ }^{207} \mathrm{~Pb} /{ }^{206} \mathrm{~Pb}^{\mathrm{d}} \\
(\mathrm{Ma})\end{array}$ & $\begin{array}{l}1 \sigma \\
(\%) \\
\end{array}$ \\
\hline \multicolumn{16}{|c|}{ Sample 06-10 } \\
\hline 3.2 & 20.2 & 13 & 0.1 & 0.1 & 0.65 & 0.00 & 98.47 & 0.5 & 15.9 & 0.90 & 2.1 & 186 & 266 & 5,132 & 41 \\
\hline 2.2 & 37.9 & 12 & 0.6 & 0.1 & 0.17 & 0.04 & 95.22 & 0.7 & 8.8 & 0.87 & 2.3 & 430 & 209 & 3,994 & 2,312 \\
\hline 1.2 & 35.8 & 14 & 0.4 & 0.1 & 0.26 & 0.03 & 90.68 & 1.1 & 8.9 & 0.83 & 3.4 & 546 & 193 & 5,951 & 3,220 \\
\hline 11.1 & 44.1 & 16 & 0.2 & 0.1 & 0.26 & 0.02 & 90.78 & 0.7 & 11.8 & 0.83 & 1.8 & 753 & 164 & 4,367 & 599 \\
\hline 3.1 & 22.5 & 10 & 0.7 & 0.1 & 0.11 & 0.07 & 85.58 & 1.3 & 9.5 & 0.79 & 1.6 & 671 & 93 & 5,412 & 82 \\
\hline 2.1 & 46.6 & 13 & 0.4 & 0.0 & 0.08 & 0.05 & 91.20 & 0.5 & 10.4 & 0.84 & 1.5 & 998 & 191 & 4,558 & 274 \\
\hline 8.1 & 20.1 & 10 & 0.4 & 0.0 & 0.13 & 0.04 & 88.22 & 0.8 & 13.8 & 0.81 & 3.2 & 895 & 256 & 5,300 & 65 \\
\hline 6.2 & 49.0 & 13 & 1.8 & 0.1 & 0.08 & 0.20 & 82.71 & 1.4 & 5.7 & 0.76 & 1.6 & 758 & 73 & 3,939 & 606 \\
\hline 1.1 & 46.6 & 20 & 0.3 & 0.1 & 0.25 & 0.03 & 80.88 & 1.4 & 12.2 & 0.75 & 5.4 & 811 & 220 & 3,358 & 2,211 \\
\hline 5.1 & 49.4 & 18 & 0.1 & 0.0 & 0.14 & 0.03 & 91.62 & 0.4 & 17.0 & 0.84 & 2.0 & 1,365 & 389 & 4,683 & 245 \\
\hline 6.1 & 18.0 & 9 & 0.2 & 0.0 & 0.23 & 0.03 & 90.73 & 0.4 & 14.2 & 0.83 & 1.6 & 1,221 & 262 & 5,227 & 29 \\
\hline 6.3 & 52.5 & 13 & 0.5 & 0.1 & 0.30 & 0.06 & 83.95 & 1.0 & 8.0 & 0.77 & 1.6 & 942 & 111 & 4,275 & 306 \\
\hline 5.2 & 44.2 & 15 & 0.2 & 0.0 & 0.09 & 0.04 & 90.66 & 0.4 & 16.6 & 0.83 & 3.4 & 1,459 & 571 & 4,393 & 607 \\
\hline 10.1 & 40.5 & 21 & 0.3 & 0.1 & 0.23 & 0.08 & 88.48 & 0.4 & 12.5 & 0.82 & 2.4 & 1,733 & 422 & 3,248 & 5,010 \\
\hline \multicolumn{16}{|c|}{ Sample 06-17 } \\
\hline 5.2 & 43.6 & 16 & 5.0 & 5.0 & 1.04 & 0.36 & 59.07 & 4.9 & 26.7 & 0.56 & 10.1 & 517 & 158 & 4,929 & 596 \\
\hline 3.2 & 30.6 & 18 & 0.2 & 0.0 & 0.19 & 0.01 & 93.54 & 0.7 & 18.9 & 0.85 & 5.6 & 554 & 482 & 5,628 & 762 \\
\hline 5.1 & 41.6 & 19 & 0.2 & 0.2 & 0.95 & 0.02 & 89.25 & 1.2 & 13.5 & 0.82 & 2.3 & 554 & 132 & 3,747 & 2,271 \\
\hline 2.3 & 35.4 & 15 & 0.2 & 0.1 & 0.33 & 0.01 & 93.53 & 0.7 & 15.1 & 0.85 & 2.0 & 582 & 199 & 6,030 & 5,146 \\
\hline 5.3 & 47.4 & 15 & 2.2 & 3.0 & 1.41 & 0.19 & 70.25 & 3.0 & 14.0 & 0.66 & 2.8 & 613 & 94 & & \\
\hline 6.1 & 67.1 & 18 & 6.3 & 2.8 & 0.47 & 0.56 & 81.49 & 1.8 & 49.2 & 0.75 & 8.7 & 642 & 402 & 4,469 & 371 \\
\hline 7.1 & 68.2 & 16 & 2.1 & 2.4 & 1.16 & 0.20 & 62.03 & 3.5 & 4.3 & 0.59 & 1.8 & 663 & 35 & 3,208 & 702 \\
\hline 13.2 & 58.7 & 15 & 2.3 & 4.5 & 2.00 & 0.22 & 70.86 & 2.7 & 4.7 & 0.66 & 3.2 & 672 & 64 & 3,496 & 700 \\
\hline 3.1 & 54.9 & 17 & 1.9 & 1.7 & 0.91 & 0.18 & 53.34 & 4.2 & 9.6 & 0.51 & 2.2 & 672 & 65 & 2,525 & 1,666 \\
\hline 12.1 & 68.3 & 17 & 2.3 & 2.4 & 1.08 & 0.22 & 62.20 & 3.3 & 4.2 & 0.59 & 1.7 & 692 & 35 & 3,241 & 704 \\
\hline 2.1 & 38.0 & 13 & 1.3 & 0.9 & 0.75 & 0.13 & 76.33 & 2.0 & 5.3 & 0.71 & 1.7 & 705 & 54 & 5,725 & 1,070 \\
\hline 12.2 & 64.4 & 15 & 2.4 & 3.3 & 1.43 & 0.24 & 50.07 & 4.2 & 3.8 & 0.49 & 4.5 & 721 & 45 & & \\
\hline 12.1 & 62.0 & 15 & 2.2 & 2.3 & 1.10 & 0.22 & 62.84 & 3.1 & 4.0 & 0.60 & 1.6 & 727 & 36 & 2,789 & 1,168 \\
\hline 12.3 & 64.1 & 17 & 2.5 & 3.6 & 1.52 & 0.26 & 59.28 & 3.3 & 4.0 & 0.57 & 3.2 & 748 & 48 & 2,445 & 1,651 \\
\hline 2.2 & 64.1 & 17 & 2.1 & 1.7 & 0.85 & 0.23 & 47.62 & 4.1 & 4.1 & 0.47 & 4.1 & 773 & 45 & 433 & 6,383 \\
\hline 8.3 & 258.1 & 22 & 10.6 & 12.8 & 1.24 & 1.19 & 15.47 & 6.5 & 2.2 & 0.20 & 4.7 & 786 & 20 & 1,319 & 681 \\
\hline 1.2 & 77.3 & 19 & 6.2 & 3.5 & 0.59 & 0.69 & 40.86 & 4.5 & 4.0 & 0.41 & 4.3 & 790 & 41 & & \\
\hline 9.1 & 76.3 & 19 & 1.8 & 2.1 & 1.22 & 0.20 & 57.97 & 3.2 & 6.0 & 0.55 & 3.5 & 799 & 63 & 3,243 & 671 \\
\hline 7.2 & 69.2 & 14 & 2.8 & 2.8 & 1.02 & 0.32 & 52.89 & 3.6 & 3.6 & 0.51 & 1.6 & 801 & 32 & 1,839 & 1,775 \\
\hline 1.1 & 37.9 & 14 & 0.4 & 0.0 & 0.10 & 0.05 & 94.60 & 0.4 & 11.9 & 0.86 & 1.7 & 825 & 275 & 3,778 & 3,485 \\
\hline 8.2 & 46.0 & 15 & 1.1 & 1.0 & 1.01 & 0.12 & 59.09 & 3.0 & 16.5 & 0.56 & 8.9 & 828 & 176 & 4,218 & 629 \\
\hline 4.2 & 268.4 & 22 & 9.8 & 6.4 & 0.68 & 1.17 & 13.00 & 6.2 & 1.9 & 0.18 & 5.6 & 844 & 19 & 867 & 910 \\
\hline 13.1 & 65.0 & 14 & 2.6 & 2.3 & 0.92 & 0.31 & 65.83 & 2.4 & 4.2 & 0.62 & 1.5 & 848 & 44 & 3,429 & 534 \\
\hline 8.1 & 43.0 & 19 & 2.1 & 2.0 & 1.02 & 0.25 & 54.52 & 3.2 & 5.9 & 0.53 & 2.6 & 857 & 57 & 5,333 & 693 \\
\hline 4.1 & 38.1 & 16 & 0.1 & 0.0 & 0.29 & 0.03 & 91.47 & 0.3 & 18.6 & 0.84 & 2.0 & 1,646 & 495 & 2,164 & 16,887 \\
\hline
\end{tabular}

${ }^{\mathrm{b}} \mathrm{Pb} *$ denotes radiogenic $\mathrm{Pb} ; \mathrm{Pb}_{\mathrm{c}}$ denotes common $\left.\mathrm{Pb} ; \mathrm{f}^{206} \mathrm{~Pb}_{\mathrm{c}}=100 *{ }^{206} \mathrm{~Pb}_{\mathrm{c}} /{ }^{206} \mathrm{~Pb}_{\text {totat }}\right)$

'Calibration concentrations and isotopic compositions were based on replicate analyses of MMs titanite (524 Ma; Schoene \& Bowring, 2006) and BLR titanite (Aleinikoff et al., 2007). Reported ratios are not corrected for common Pb. Errors are reported as percent at the $1 \sigma$ level.

${ }^{\mathrm{d}}$ Common $\mathrm{Pb}$ isotopic composition determined by $3 \mathrm{D}$ linear regression on a Tera-Wasserburg plot which gave a data-defined ${ }^{207} \mathrm{~Pb} /{ }^{206} \mathrm{~Pb}$ upper intercept of 0.9096 . Ages were calculated from ${ }^{206} \mathrm{~Pb} /{ }^{23}$ ratios corrected for common $\mathrm{Pb}$ using the ${ }^{207} \mathrm{~Pb}$ method and ${ }^{207} \mathrm{~Pb} /{ }^{206} \mathrm{~Pb}$ ratios corrected for common $\mathrm{Pb}$ using the ${ }^{204} \mathrm{~Pb}$ method (see Williams, 1998). Uncertainties in millions of years reported as $1 \sigma$. 
Table 5

SIMS U-Pb geochronologic monazite data and apparent ages.

\begin{tabular}{|c|c|c|c|c|c|c|c|c|c|c|c|c|c|}
\hline Spot $^{a}$ & ${ }^{206} \mathrm{~Pb} /{ }^{204} \mathrm{~Pb}$ & $\begin{array}{l}1 \sigma \\
(\%)\end{array}$ & $\begin{array}{c}U \\
(\mathrm{ppm})\end{array}$ & $\begin{array}{c}\text { Th } \\
\text { (ppm) }\end{array}$ & $\mathrm{Th} / \mathrm{U}$ & $\begin{array}{c}{ }^{206} \mathrm{~Pb}^{* b} \\
(\mathrm{ppm})\end{array}$ & $f^{206} \mathrm{~Pb}_{\mathrm{c}}{ }^{\mathrm{b}}$ & ${ }^{238} \mathrm{U} /{ }^{206} \mathrm{~Pb}^{\mathrm{c}}$ & $\begin{array}{r}1 \sigma \\
(\%)\end{array}$ & ${ }^{207} \mathrm{~Pb} /{ }^{206} \mathrm{~Pb}^{\mathrm{c}}$ & $\begin{array}{r}1 \sigma \\
(\%)\end{array}$ & $\begin{array}{c}{ }^{206} \mathrm{~Pb} /{ }^{238} \mathrm{U}^{\mathrm{d}} \\
(\mathrm{Ma})\end{array}$ & $\begin{array}{l}1 \sigma \\
(\%)\end{array}$ \\
\hline \multicolumn{14}{|c|}{ Sample 06-115 } \\
\hline $1-1.1$ & 35 & 12 & 947 & 5290 & 5.8 & 6.6 & 50.01 & 62 & 2.6 & 0.443 & 4.7 & 52 & 3 \\
\hline $5-1.1$ & 262 & 19 & 1391 & 5388 & 4.0 & 11.6 & 6.77 & 96 & 4.5 & 0.101 & 4.9 & 62 & 3 \\
\hline $2-2.1$ & 64 & 12 & 1279 & 5535 & 4.5 & 10.5 & 42.11 & 61 & 4.5 & 0.381 & 9.3 & 61 & 5 \\
\hline $5-2.1$ & 139 & 27 & 1895 & 31614 & 17.2 & 16.3 & 9.05 & 91 & 3.1 & 0.119 & 8.8 & 64 & 2 \\
\hline $4-3.1$ & 79 & 13 & 1754 & 4340 & 2.6 & 15.0 & 34.59 & 66 & 3.8 & 0.321 & 4.5 & 64 & 3 \\
\hline $8-3.1$ & 85 & 22 & 2238 & 10160 & 4.7 & 19.4 & 24.93 & 75 & 4.9 & 0.245 & 10.1 & 65 & 4 \\
\hline $8-4.1$ & 72 & 8 & 1578 & 3031 & 2.0 & 14.0 & 23.53 & 74 & 3.1 & 0.234 & 1.3 & 66 & 2 \\
\hline $2-1.1$ & 52 & 8 & 1272 & 2455 & 2.0 & 11.4 & 37.21 & 60 & 4.5 & 0.342 & 8.5 & 67 & 5 \\
\hline $4-1.1$ & 449 & 19 & 1211 & 1895 & 1.6 & 11.2 & 6.70 & 86 & 2.6 & 0.100 & 2.2 & 69 & 2 \\
\hline $10-2.1$ & 72 & 10 & 1289 & 2737 & 2.2 & 12.0 & 33.30 & 62 & 3.0 & 0.311 & 2.6 & 69 & 2 \\
\hline $12-2.1$ & 82 & 8 & 1110 & 3617 & 3.4 & 10.9 & 18.07 & 72 & 1.7 & 0.191 & 5.0 & 73 & 2 \\
\hline $9-2.1$ & 149 & 12 & 1277 & 2956 & 2.4 & 12.6 & 10.47 & 78 & 1.7 & 0.131 & 3.2 & 74 & 1 \\
\hline $9-1.1$ & 320 & 13 & 1343 & 4684 & 3.6 & 13.4 & 5.54 & 81 & 2.6 & 0.091 & 3.4 & 74 & 2 \\
\hline 8-1.1 & 490 & 18 & 1877 & 5349 & 2.9 & 19.1 & 3.46 & 81 & 1.9 & 0.075 & 2.0 & 76 & 1 \\
\hline $8-2.1$ & 93 & 11 & 1063 & 2861 & 2.8 & 10.8 & 29.29 & 60 & 2.9 & 0.280 & 3.5 & 75 & 3 \\
\hline $12-1.1$ & 175 & 10 & 1131 & 2587 & 2.4 & 12.1 & 11.56 & 71 & 1.7 & 0.139 & 1.5 & 80 & 1 \\
\hline $4-2.1$ & 143 & 12 & 1904 & 12440 & 6.8 & 22.2 & 19.09 & 60 & 3.0 & 0.199 & 3.1 & 87 & 3 \\
\hline $10-1.1$ & 93 & 10 & 1702 & 24941 & 15.1 & 21.9 & 20.05 & 53 & 2.1 & 0.207 & 3.3 & 96 & 2 \\
\hline $6-1.1$ & 117 & 12 & 1537 & 45229 & 30.4 & 22.3 & 20.15 & 47 & 4.4 & 0.208 & 1.8 & 108 & 5 \\
\hline $3-1.1$ & 205 & 18 & 810 & 39544 & 50.5 & 15.7 & 5.48 & 42 & 3.1 & 0.093 & 3.1 & 144 & 4 \\
\hline $3-2.1$ & 82 & 17 & 907 & 26904 & 30.6 & 19.2 & 14.41 & 35 & 3.6 & 0.164 & 3.5 & 157 & 6 \\
\hline \multicolumn{14}{|c|}{ Sample 06-1 } \\
\hline 3.1 & 37 & 25 & 4419 & 28129 & 6.6 & 20.7 & 50.96 & 90 & 49.1 & 0.450 & 2.3 & 35.1 & 17 \\
\hline 2.1 & 455 & 30 & 199 & 3481 & 18.0 & 4.1 & 2.63 & 41 & 1.8 & 0.070 & 10.7 & 153 & 3 \\
\hline 1.1 & 550 & 32 & 265 & 4766 & 18.6 & 5.7 & 1.81 & 39 & 2.8 & 0.064 & 4.0 & 161 & 4 \\
\hline
\end{tabular}

${ }^{a}$ Label format is grain number.spot number

${ }^{\mathrm{b}} \mathrm{Pb} *$ denotes radiogenic $\mathrm{Pb} ; \mathrm{Pb}_{\mathrm{c}}$ denotes common $\mathrm{Pb} ; \mathrm{f}^{206} \mathrm{~Pb}_{\mathrm{c}}=100 *\left({ }^{206} \mathrm{~Pb}_{\mathrm{c}}{ }^{206} \mathrm{~Pb}_{\text {total }}\right)$

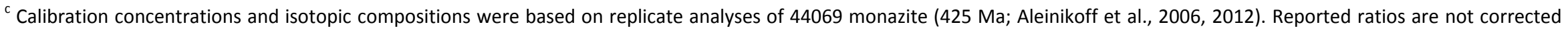
for common $\mathrm{Pb}$. Errors are reported as percent at the $1 \sigma$ level.

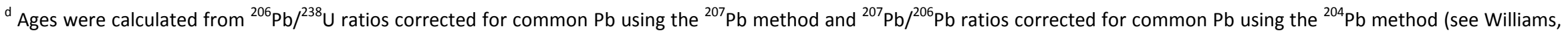
1998). Initial common Pb isotopic composition approximated from Stacey \& Kramers (1975). Uncertainties in millions of years reported as 1б. Apparent ages in bold are used in age calculations discussed in the text. 
Table 6

SIMS U-Pb geochronologic xenotime data and apparent ages.

\begin{tabular}{|c|c|c|c|c|c|c|c|c|c|c|c|}
\hline $\operatorname{Spot}^{a}$ & $\begin{array}{c}U \\
(\mathrm{ppm})\end{array}$ & $\begin{array}{c}\text { Th } \\
\text { (ppm) }\end{array}$ & $\mathrm{Th} / \mathrm{U}$ & $\begin{array}{c}{ }^{206} \mathrm{~Pb}^{* b} \\
(\mathrm{ppm})\end{array}$ & $\mathrm{f}^{206} \mathrm{~Pb}_{\mathrm{c}}^{\mathrm{b}}$ & ${ }^{238} \mathrm{U} /{ }^{206} \mathrm{~Pb}^{\mathrm{c}}$ & $\begin{array}{l}1 \sigma \\
(\%)\end{array}$ & ${ }^{207} \mathrm{~Pb} /{ }^{206} \mathrm{~Pb}^{\mathrm{C}}$ & $\begin{array}{l}1 \sigma \\
(\%)\end{array}$ & $\begin{array}{c}{ }^{206} \mathrm{~Pb} /{ }^{238} \mathrm{U}^{\mathrm{d}} \\
(\mathrm{Ma})\end{array}$ & $\begin{array}{l}1 \sigma \\
(\%)\end{array}$ \\
\hline \multicolumn{12}{|c|}{ Sample 06-1 } \\
\hline $3-1.3$ & 6640 & 6612 & 1.03 & -0.430 & 145 & 39.5 & 3.0 & 0.0459 & 2.9 & 162 & 5 \\
\hline 4-1.1 & 4053 & 1707 & 0.44 & 0.097 & 93 & 37.4 & 3.1 & 0.0503 & 3.4 & 170 & 5 \\
\hline 3-1.1 & 4687 & 3818 & 0.84 & -0.335 & 112 & 35.9 & 5.2 & 0.0470 & 2.5 & 177 & 9 \\
\hline $3-1.2$ & 5450 & 4493 & 0.85 & -0.058 & 133 & 35.2 & 3.5 & 0.0493 & 2.1 & 181 & 6 \\
\hline $2-1.1$ & 10579 & 754 & 0.07 & 0.106 & 269 & 33.7 & 4.1 & 0.0507 & 2.9 & 188 & 8 \\
\hline 5-1.1 & 19116 & 16396 & 0.89 & 0.877 & 487 & 33.4 & 5.2 & 0.0569 & 1.4 & 188 & 10 \\
\hline \multicolumn{12}{|c|}{ Sample 06-115 } \\
\hline $10-1.1$ & 8393 & 4994 & 0.61 & 16.617 & 156 & 38.6 & 3.9 & 0.1811 & 3.3 & 139 & 8 \\
\hline
\end{tabular}

${ }^{\mathrm{a}}$ Label format is grain number.spot number

${ }^{\mathrm{b}} \mathrm{Pb} *$ denotes radiogenic $\mathrm{Pb} ; \mathrm{Pb}_{\mathrm{c}}$ denotes common $\mathrm{Pb} ; \mathrm{f}^{206} \mathrm{~Pb}_{\mathrm{c}}=100 *\left({ }^{206} \mathrm{~Pb}_{\mathrm{c}}{ }^{206} \mathrm{~Pb}_{\text {total }}\right)$

${ }^{c}$ Calibration concentrations and isotopic compositions were based on replicate analyses of MG-1 xenotime (490 Ma; Fletcher et al., 2010 ; Aleinikoff et al., 2012). Reported ratios are not corrected for common Pb. Errors are reported as percent at the $1 \sigma$ level.

${ }^{\mathrm{d}}$ Ages were calculated from ${ }^{206} \mathrm{~Pb} /{ }^{238} \mathrm{U}$ ratios corrected for common $\mathrm{Pb}$ using the ${ }^{207} \mathrm{~Pb}$ method and ${ }^{207} \mathrm{~Pb} /{ }^{206} \mathrm{~Pb}$ ratios corrected for common $\mathrm{Pb}$ using the ${ }^{204} \mathrm{~Pb}$ method (see Williams, 1998). Initial common Pb isotopic composition approximated from Stacey \& Kramers (1975). Uncertainties in millions of years reported as $1 \sigma$. 
Supplementary Material Figure SM1
Click here to download Supplementary Interactive Plot Data (CSV): Supplementary Material_FigSM1-FINAL.docx

Supplementary Material Figure SM1
Click here to download Supplementary Interactive Plot Data (CSV): Supplementary Material_FigSM1-FINAL.docx 

Supplementary Material Table SM1
Click here to download Supplement

Click here to download Supplementary Interactive Plot Data (CSV): Table SM1 COMPLETO_FINAL.xIsx ( 